Київський національний торговельно-економічний університет Кафедра банківської справи

DOI: http://doi.org/10.31617/k.knute.2019-05-15.01

\title{
ФІНАНСОВО-КРЕДИТНІ СИСТЕМИ В УМОВАХ ЗМІНИ ДІЛОВИХ ЦИКЛІВ
}

\author{
ТЕЗИ ДОПОВІДЕЙ \\ МІЖНАРОДНОЇ НАУКОВО-ПРАКТИЧНОЇ \\ IНТЕРНЕТ-КОНФЕРЕНЦІЇ
}

(Київ, 15 травня 2019 р.) 


\section{Розповсюдження і тиражування без офіційного дозволу КНТЕУ заборонено}

\section{УДК 336.7}

Ф 59

Фінансово-кредитні системи в умовах зміни ділових циклів:

Ф 59 Міжн. наук.-практ. Інтернет-конф. (Київ, 15 травня 2019 р.): тези доп. / відп. ред. Н.П. Шульга - Київ.: Київ. нац. торг.-екон. ун-т. 161 с. - Укр. та англ. мовами.

ISBN 978-966-629-938-6

У збірнику подані тези доповідей за матеріалами Міжнародної науковопрактичної Інтернет-конференції, в яких розглядаються актуальні питання модернізації фінансово-кредитної системи в умовах зміни ділових циклів; регулювання діяльності окремих суб'єктів системи в Україні та світі; впливу глобальних процесів на фінансовий ринок України. Визначено фактори економічного та нормативно-правового характеру, що чинять вплив на стан фінансово-кредитної системи, інструменти стимулювання розвитку фінансовокредитних установ та фінансової інклюзії.

Матеріали друкуються в авторській редакції, окрім можливої зміни їх назви. Відповідальність за зміст та інтерпретацію матеріалів несуть автори.

Редакційна колегія: А. А. Мазаракі, ректор КНТЕУ, д.е.н., проф., голова організаційного комітету; С. В. Мельниченко, проректор з наукової роботи КНТЕУ, д.е.н., проф., заступник голови організаційного комітету; В. М. Сай, проректор 3 науково-педагогічної роботи та міжнародних зв'язків КНТЕУ, к.е.н., доцент; Т. В. Канєва, декан факультету фінансів та банківської справи КНТЕУ, к.е.н., доцент; Н. П. Шульга, завідувач кафедри банківської справи КНТЕУ, д.е.н., проф.; Т. М. Гордієнко, к.е.н. доц.; Л. А. Гербич, к.е.н. доц.; Л. О. Нетребчук, ст. викладач.

Відповідальний за випуск: Н. П. Шульга, завідувач кафедри банківської справи КНТЕУ, д.е.н, проф. 


\section{MICT}

Вступне слово

\section{СЕКЦІЯ 1. ЦИКЛІЧНІСТЬ ЕКОНОМІЧНИХ ПРОЦЕСІВ: ТЕОРІЇ ТА ІНСТРУМЕНТИ ОЦІНЮВАННЯ ВПЛИВУ НА ФІНАНСОВО-КРЕДИТНІ СИСТЕМИ}

Антонюк О. А., Чорний А. Ю.

Ідентифікація структурних зсувів макроекономічних показників

Благун I. I.

Вітчизняний фінансовий ринок: фактори впливу

Бублик Є. О.

Міжнародні потоки капіталу - драйвер економічних циклів

Гербст О. Л.

Процентна політика СЦБ і ФРС

Клименко К. В., Савостьяненко М. В.

Стратегічні орієнтири розвитку співробітництва України 3 Свропейським інвестиційним банком

Міщенко В. І., Льон І. М.

Процентна політика: ключові напрями вдосконалення

Науменкова С. В.

Монетарна та бюджетна політика України: етапи взаємодії

Нежива М. $\mathrm{O}$.

Креативна економіка - ключовий вектор розвитку держави

Сундук Т. Ф.

Розвиток вітчизняного ринку кредитних послуг

Циганова Н. В.

Ресурсне забезпечення діяльності банків в умовах циклічності економічного розвитку

Шимла Войтек, Колегович Конрад, Познякова О. I.

Ефект витіснення в контексті політики внутрішніх запозичень України 


\section{СЕКЦЯ 2. ЗАХИСНА ТА ПРЕВЕНТИВНА СИСТЕМИ РЕГУЛЮВАННЯ ДІЯЛЬНОСТІ ФІНАНСОВИХ УСТАНОВ В УМОВАХ ЗМІНИ ДІЛОВИХ ЦИКЛІВ}

Белянко Л. Л.

Стрес-тестування банків та його роль у формуванні ділової активності країни

Верезубова Т. А., Косякова А. А.

Solvency II - захисна система регулювання діяльності страхових організацій

Гербич Л. А.

Детермінанти превентивного антикризового управління банком

Гнатченко Д. Д.

Кібербезпека банківської системи України

Городянська Л. В., Носенко Т. І.,

Безпека банківської системи України

Еркес О. С.

Норматив ліквідності NSFR: методика визначення

Жердецька Л. В.

Захисне та превентивне регулювання системного ризику банківського сектору

Жердецька Л. В., Черниш К. С.

Ідентифікація епізодів системної банківської кризи

Кірєєва К. О.

Валютне регулювання в Україні: реалії розвитку

Недеря Л. В.

Оцінювання безперервності діяльності банку

Нетребчук Л. О.

Неякісні кредити банків: зміна підходу до визначення

Огородник В. В.

Банки 3 державною участю та їх вплив на монетарну політику

Плонка Марія, Тринчук В. В., Зелениця I. М.

Державний страховий нагляд країн СС: досвід для України 
Смірнова Т. О., Митровці М.

Підвищення рівня фінансової надійності страхових компаній

Степаник А. О.

Механізм bail-in - інструмент фінансового оздоровлення

банків

Шульга Н. П.

Управління ризиками в банках України: зміна стереотипів

\section{СЕКЦІЯ З. ПІДПРИЕМНИЦЬКА ДІЛОВА АКТИВНІСТЬ В} БІЗНЕС-ЦИКЛІВ

Головач Н. А.

Ділова активність підприємства в бізнес-циклі

Гуминська М. В.

Контролінг в забезпеченні платоспроможності страхових організацій

Danylkiv Kh. P.

Financial-credit instruments innovative development of small enterprise structures in Ukraine

Душак М. I.

Управління капіталом як базовий елемент фінансової архітектури підприємств

Жердецька Л. В., Овчинникова О. О.

Банки та банківський бізнес: наукові підходи до визначення

Кансва Т. В., Шевченко С. О.

Облік запасів в установах державного сектору

Маслова Н. О.

Маркетингова стратегія банку

Назарова К. О.

SOX-аудит в забезпеченні фінансової стабільності держави

Плісак Т. О.

Вплив МСФ3 9 «Фінансові інструменти» на фінансову звітність банку

Роздобудько В. В.

Аудит фінансової звітності фінансових установ 
Романишин В. О.

Торговельне фінансування у забезпеченні структурної трансформації національної економіки

Рязанцева В. В.

Дослідження циклічних процесів на основі дистрибутивнолагових та авторегресивних моделей

Степанова І. В., Яременко А. М.

Фінансова стратегія - інструмент стабілізації підприємства

\section{СЕКЦІЯ 4. ФІНАНСОВА ІНКЛЮЗІЯ ТА ЗАХИСТ ПРАВ СПОЖИВАЧІВ ФІНАНСОВИХ ПОСЛУГ}

Аванесова I. A.

Фінансова інклюзія у досягненні цілей сталого розвитку

Ануфрісва К. В.

Фінансова інклюзія в реаліях малої відкритої економіки

Бортніков Г. П.

Освітні вклади в Україні

Брус C. I.

Оцінка фінансування корпоративного сектору інститутами спільного інвестування

Вінська О. Й., Токар В. В.

Зменшення гендерного розриву в СС: фінансовий аспект

Жураховська Л. В.

Справедлива оцінка репутації банку як захист прав інвесторів

Клапків Ю. М.

Раціональність та ірраціональність споживача страхової послуги

Котенко У. М.

Фінансова інклюзія в Україні: передумови зростання

Krivoruchko S.

Impact of remittances on economic growth

Міщенко С. В., Дорофесв Д. А.

Етапи інноваційного розвитку небанківського вітчизняного фінансового сектору 
Пожидаєва М. А.

Щодо питання невиконання або неналежного виконання платіжного доручення на переказ коштів до бюджету

Ховрак I. В.

Соціальна відповідальність установ та іiі вплив на лояльність споживачів фінансових послуг

Шаповал Ю. І.

ФінТех як інструмент підвищення фінансової інклюзії бізнесу

\section{СЕКЦІЯ 5. ХАЙП-ЦИКЛ РОЗВИТКУ ФІНАНСОВИХ ТЕХНОЛОГІЙ}

Волосович С. В.

Домінанти розвитку цифрового банкінгу

Gordiienko T. M.

Legislative initiatives for the digital transformation of banking business

Городянська Л. В.

Особливості функціонування необанків

Гут Л. В.

Необанки: зарубіжний та вітчизняний досвід функціонування

Калита О. В.

Віртуальні банки: перспективи розвитку

Озерчук О. В.

On-line банки: зарубіжний досвід

Serazhym Y. V.

The hype cycle for emerging technologies on the boundary between man and machine

Підвисоцький Я. В.

Біо-цикл та хайп-цикл зародження і розвитку інноваційних фінансових інструментів

Шуплат О. М.

Хайп-цикл блокчейна та криптовалют 


\section{ВСТУПНЕ СЛОВО}

\section{Шановні колеги!}

Щиро вітаю організаторів, учасників та гостей Міжнародної науково-практичної Інтернет-конференції «Фінансово-кредитні системи в умовах зміни ділових циклів»!

Дослідження циклічного характеру економіки, виявлення особливостей розвитку фінансово-кредитних систем на різних етапах ділових циклів постійно перебувають у центрі уваги наукової спільноти.

Сучасний етап розвитку фінансово-кредитних систем характеризується активним впровадженням передових технологій, зокрема, блокчейн, цифрових банків, різноманітних мобільних додатків, хмарних технологій тощо. Тісна взаємозалежність між економічним ростом та розвитком фінансово-кредитних систем вимагає постійного її вивчення.

Нинішній науково-просвітницький форум покликаний дослідити: теоретичні підходи та інструменти оцінювання впливу циклічності економічних процесів на фінансово-кредитні системи; особливості захисних та превентивних систем регулювання діяльності фінансових установ та підприємницької ділової активності в умовах зміни ділових циклів. Особливої уваги заслуговує прагнення учасників конференції провести дискусію щодо фінансової інклюзії та захисту прав споживачів фінансових послуг, а також хайп-циклу розвитку фінансових технологій.

Тематика доповідей науковців відображає глобальні виклики, які нині стоять перед фінансово-кредитними системами. Дуже дякую іноземним партнерам за долучення до обговорення проблем, які постають перед вченими та практиками в умовах постійної 
волатильності економіки. Висловлюю вдячність за участь у конференції колегам із закладів вищої освіти Білорусі, Канади, Польщі, Росії, США. Маю впевненість, що міжнародне спілкування дозволить обмінятися корисним досвідом та сформувати спільні вектори дій для подальшої співпраці. Вірю, що Міжнародна науково-практична Інтернет-конференція «Фінансово-кредитні системи в умовах зміни ділових циклів» стане постійним майданчиком для обговорення актуальних питань, обміну досвідом, комунікації науковців та професіоналів у сфері фінансів та кредиту. розвитку фінансовокредитних систем.

3 глибокою повагою Анатолій Мазаракі, ректор КНТЕУ, доктор економічних наук, професор, академік Національної академії педагогічних наук України, заслужений діяч науки $і$ техніки України, лауреат Державної премії Украӥни в галузі науки і техніки 


\title{
СЕКЦІЯ 1. ЦИКЛІЧНІСТЬ ЕКОНОМІЧНИХ ПРОЦЕСІВ: ТЕОРІЇ ТА ІНСТРУМЕНТИ ОЦІНЮВАННЯ ВПЛИВУ НА ФІНАНСОВО-КРЕДИТНІ СИСТЕМИ
}

\author{
Антонюк О. А. \\ ст. викладач, \\ ORCID ID: https://orcid.org/0000-0003-4419-5789 \\ Чорний А. Ю. \\ к.е.н., доиент, \\ ORCID ID: https://orcid.org/0000-0001-9292-8831 \\ Киїський національний торговельно-економічний університет, \\ м. Київ, Україна

\section{ІДЕНТИФІКАЦІЯ СТРУКТУРНИХ ЗСУВІВ МАКРОЕКОНОМІЧНИХ ПОКАЗНИКІВ}

Моделювання впливу макроекономічних показників на фінансово-кредитну систему за допомогою економетричних моделей передбачає правильну ідентифікацію змінних щодо їх стаціонарності.

Виходячи з дискусії, яку розпочав П’єр Перрон у 1989 році [2], традиційні тести на одиничний корінь майже завжди будуть підтверджувати гіпотезу про наявність одиничного кореня, а отже, нестаціонарність ряду, якщо в ньому міститься структурний зсув.

Тому, для коректної перевірки наявності одиничних коренів у процесах з можливими структурними зламами було запропоновано ряд тестів [3, 4].

Оскільки реальний ВВП є важливою складовою значного числа досліджень фінансово-кредитної системи було проведене дослідження наявності одиничних коренів в його динаміці за можливих структурних змін. В якості досліджуваного показника було обрано 
обсяги реального ВВП скоригованого за дефлятором ВВП у постійних цінах 2010 року за період з 2000 по 2018 рік [1].

Динаміка ВВП має чітко виражені сезонні коливання, тому було проведено сезонне коригування за процедурою $X$-12. Дослідження динаміки дозволяє чітко виділити два періоди зламів. Використання застосованих тестів може бути ефективним тільки за наявності одного зсуву, тому для перевірки стаціонарності при першому зламі обрано період 2002Q1 по 2013Q4, а другого - з 2009Q2 по 2018Q4 (табл. 1).

Таблиия 1

\section{Результати перевірки стаціонарності ВВП}

\begin{tabular}{|c|c|c|c|c|}
\hline Період & $\begin{array}{c}\text { Тестова } \\
\text { статистика }\end{array}$ & Критичне значення & $\begin{array}{c}\text { Визначений } \\
\text { час зсуву }\end{array}$ & Висновок \\
\hline $\begin{array}{c}2002 Q 1- \\
\text { 2013Q4 }\end{array}$ & -7.75 & $\begin{array}{c}-5.175710 \\
\text { (за рівня значущості 5\%) }\end{array}$ & 3 кв. 2008 & Стаціонарність \\
\hline $\begin{array}{c}\text { 2009Q2 - } \\
\text { 2018Q4 }\end{array}$ & -4.927937 & $\begin{array}{c}-4.893950 \\
\text { (за рівня значущості 10\%) }\end{array}$ & 3 кв. 2014 & Стаціонарність \\
\hline
\end{tabular}

Джерело: обчислено авторами за допомогою пакета E.view 9.5.

Оскільки тестові значення за абсолютними значеннями перевищують критичні, то результати тестів дозволяють дійти висновку про стаціонарність у досліджуваних періодах реального ВВП відносно тренду з структурним зсувом в його параметрах.

\section{Список використаних джерел}

1. Державна служба статистики України. - [Електронний peсурс]. Режим доступу: http://ukrstat.gov.ua.

2. Perron, P. (1989) The Great Crash, the Oil Price Shock, and the Unit Root Hypothesis, Econometrica, 57, 1361-1401.

3. Vogelsang, T.J. (1997) Wald-Type Test For Detecting Breaks In The Trend Function Of a Dynamic Time Series, Econometric Theory, 13, 818-849.

4. Zivot E. and D.W. Andrews (1992) Further Evidence on the Great Crash, the Oil-Price Shock, and the Unit-Root Hypotheses, Journal of Business and Economic Statistics, 10, 251-270. 


\section{Благун I. I. к.е.н., викладач}

Прикарпатський національний університет імені Василя Стефаника м. Івано-Франківськ, Україна ORCID ID: https://orcid.org/0000-0002-5178-6002

\section{ВІТЧИЗНЯНИЙ ФІНАНСОВИЙ РИНОК: ФАКТОРИ ВПЛИВУ}

Фінансовий ринок України наразі знаходиться в критичному стані, оскільки за останні декілька років спостерігається скорочення обсягів фінансових активів в економіці. Це обумовлено цілим рядом причин, основними 3 яких $є$ макроекономічна нестабільність, яка пов'язана із політичною ситуацією в країні, а також політика фінансових регуляторів, спрямована на очищення фінансового ринку від спекулятивних операцій [1].

Водночас така характеристика на нашу думку $\epsilon$ досить поверхневою. Для більш повного розуміння ситуації, а особливо для визначення тенденцій його подальшого розвитку та прогнозування фінансових ризиків проведених чи запланованих операцій важливого значення набуває визначення факторів, що можуть мати як першочерговий так і другорядний вплив. Особливо аналіз факторів стає актуальним, оскільки все частіше прогноз динаміки ринку характеризується такою ознакою як невизначеність, яку складно спрогнозувати.

Існують різні класифікаційні ознаки, за якими групують фактори. На наш погляд, найбільш доречною є класифікація за ознакою ендо- та екзогенності по відношенню до операцій, що проводяться на фінансовому ринку. Серед екзогенних факторів, що визначають стан фінансового ринку України ззовні та є системними, варто виокремити наступні: сформовану структуру власності в рамках національної 
економіки, тобто включаючи і реальний і фінансовий сектори; структуру національної економіки за видами економічної діяльності, та іiї тяжіння до сировинних видів економічної діяльності; циклічність розвитку національної економіки, хоча даний фактор в Україні майже не працює в силу вагомого впливу політичної нестабільності; модель економічної поведінки населення, яка в першу чергу визначається розподілом отриманих доходів на споживання та заощадження, частка останнього у зв'язку з постійними кризовими явищами в економіці стабільно зменшується, що знижує інвестиційну активність а також підриває довіру до фінансових установ; рівень розвитку корпоративного управління, який значно покращився в останні роки в банківській сфері, що обумовлено в першу чергу регуляторними вимогами щодо управління комплаєнс ризиком, чого не можна констатувати в реальному секторі економіки, і що суттєво нарощує ризики фінансових операцій, тощо [2].

Серед ендогенних чинників найбільш значимими $є$ рівень інтегрованості національного фінансового ринку у світовий, що визначає значну залежність його стану від глобальний фінансових процесів, враховуючи, що економіка України є малою та відкритою; фінансова глибина економіки; попит та пропозиція на фінансові інструменти 3 боку інвесторів та реципієнтів інвестицій; рівень розвитку фінансових посередників, в тому числі і їх інформаційнотехнологічне забезпечення; сформована залежність між фінансовим та товарним ринками; транспарентність як фінансових посередників так і операцій, тощо.

\section{Список використаних джерел}

1. Благун I.I. Аномалії на фінансових ринках як фактор ірраціональної поведінки інвесторів // Науковий вісник Ужгородського університету. Серія: Економіка. - 2017. -Випуск 2 (50). - С.239-244. 
2. Благун I.I. Особливості формування раціональної поведінки учасників фінансового ринку // Наукові записки національного університету «Острозька академія». - 2017. - №5(33). - С.52-56.

Бублик С. О. к.е.н., стариий науковий співробітник ДУ «Інститут економіки та прогнозування НАНУ», м. Київ, Украӥна ORCID ID: https://orcid.org/0000-0002-6080-9341

\section{МІЖНАРОДНІ ПОТОКИ КАПІТАЛУ - ДРАЙВЕР ЕКОНОМІЧНИХ ЦИКЛІВ}

Зростання обсягів та волатильності міжнародного капіталу досягло таких масштабів, що він почав відігравати значну роль у формуванні економічних циклів (ЕЦ) країн та цілих регіонів. Проциклічний характер потоків капіталу наочно проявився в Азійському регіоні 1997 р., а також в країнах 3 ринками, що розвиваються (КРР) у 2008 р. Визначення особливостей проциклічної взаємодії потоків капіталу в різних типах економік, а також пошук шляхів їх регулювання в інтересах стабільного економічного зростання набуває все більшої актуальності для наукової думки.

Вплив потоків капіталу на формування ЕЦ в розвинених економіках (РЕ) відрізняється більш розміреним проциклічним характером порівняно із КРР. Період зростання ділової активності в країнах «Великої сімки» збігається із періодом активізації притоку капіталу. [1] Така закономірність підтверджує теорію руху капіталу в напрямку максимізації прибутку. Разом з тим, низка ознак викликає сумніви, щодо адекватності неокласичної теорії в частині пояснення поведінки інвесторів, які спрямовують потоки капіталу. 
В першу чергу, це - низька відповідність рівня відсоткових ставок напряму потоків капіталу: попри майже нульові ставки в РЕ і значно вищі ставки в КРР, це досить обмежено позначається на перерозподілі потоків капіталу на користь останніх. На КРР припадає до 2\% обсягів притоку капіталу по відношенню до світового ВВП. Тоді як на РЕ - все ще більше 5\%. [2]

Стосовно КРР, в умовах обмеженої дії відсоткових ставок, характер потоків капіталу визначається поведінкою міжнародних інвесторів. Згідно останніх досліджень: визначальним для притоку іноземних інвестицій виступає фактор сприйняття ризикового потенціалу цільової економіки. Він, навіть, переважає фактор потенціалу іï зростання. [3]

В умовах уповільнення ділової активності в РКК, притік іноземного капіталу переважно у формі боргових інструментів та портфельних інвестицій абсорбується через цінові бульбашки, фінансування дефіциту платіжного балансу та бюджету. Тим самим накопичується системний ризик, який доповнюється притаманними РКК валютному і борговому ризиками і малими обсягами ЗВР. За перших ознак проходу «піку» ЕЦ і розгортання цінового тренду, такий капітал «втікає» з РКК, прискорюючи темпи падіння цін на активи i поглиблюючи рецесію.

Таким чином, для економік КРР міжнародний капітал відіграє значну проциклічну роль саме в кінцевому етапі ЕЦ, а зміна структури притоку капіталу на користь збільшення частки портфельних інвестицій та боргового фінансування, за певних умов, може слугувати індикатором завершення економічного циклу. 


\section{Список використаних джерел}

1. Contessi S., De Pace P., Francis J. The cyclical properties of disaggregated capital flows /Journal of International Money and Finance., 2013. - vol. 32(C). - p. 528-555.

2. The IMF Data. [Електронний ресурс] / офіц. сайт МВФ. - Режим доступу : https://www.imf.org/en/Data

3. Hannan S. The Drivers of Capital Flows in Emerging Markets Post Global Financial Crisis. - IMF Working Paper. - WP/17/52, 2017

Гербст О. Л.

аспірант

Київський національний торговельно-економічний університет, м. Київ, Украӥна

\section{ПРОЦЕНТНА ПОЛІТИКА ЄЦБ і ФРС}

Процентна політика ЄЦБ з 1999 року була послідовною в дотриманні основної мети з 1999. Однак, під час недавньої світової фінансової кризи 2008 року, СЦБ був вимушений застосувати ряд нестандартних заходів у власній процентній політиці. Для ефективного подолання фінансової кризи ЄЦБ і ФРС швидко і різко реагували на перебіг подій під час кризи 2008 року і своєчасно вживали безпрецедентні заходи у власній монетарній і процентній політиці.

Систематизація і порівняння заходів процентної політики ЄЦБ і ФРС за часів кризи виявляються необхідними з огляду запозичення досвіду світових лідерів фінансового сектору при боротьбі з кризовими явищами, який може бути і є важливим для використання в Україні 3 метою подолання теперішньої економічної кризи.

Економісти вважають, що під час світової фінансової кризи запорукою ефективності процентної політики і застосування нестандартних фінансових інструментів центральними банками $\mathrm{CC}$ i США, були не причина кризових явищ у фінансовому секторі, не 
структура державних фінансів або фінансового ринку, а саме розмір економіки держави і стан основних макроекономічних показників.

Економіка $\mathrm{CC} є$ великою і відносно закритою економікою, отже, структурні риси єврозони є порівнюваними із США. 3 точки зору розміру населення, економіка $\mathrm{E} \in$ найбільшою розвинутою економікою в світі. Тим не менш, в 2009 р. частка економіки ЄС у світовому ВВП складала 15,1\%, а частка США 20,4\% (табл. 1).

Таблиия 1

Основні економічні та фінансові показники країн СС та США на початку глобальної фінансової кризи в 2009

\begin{tabular}{|l|c|c|}
\hline \multicolumn{1}{|c|}{ Показник } & СС & США \\
\hline Населення, млн. чоловік & 330.5 & 307.5 \\
\hline ВВП (доля світового ВВП), \% & 15.1 & 20.4 \\
\hline Рівень безробіття, \% & 64.7 & 67.6 \\
\hline Рівень інфляції, \% & 1.7 & 2.7 \\
\hline Загальна сума банківських кредитів, млрд. євро & 15800 & 14000 \\
\hline Сумарні резерви банківської системи, млрд. євро & 400 & 600 \\
\hline Доля резервів у загальній сумі банківських кредитів, \% & 2.25 & 9.65 \\
\hline Ключова процентна ставка, \% & 1.25 & 0 \\
\hline
\end{tabular}

Джерело: розроблено автором за матеріалами $[1,2]$

У фінансовій структурі економіки $\mathrm{CC}$, на відміну від економіки США, банки відіграють важливу роль у фінансуванні економіки і в трансмісійному механізмі. ФРС США, яка проводить переважно операції з прямої купівлі та продажу активів на відкритому ринку і має більшою присутність на світових ринках капіталу.

Заходи $з$ процентної політики для подолання фінансової кризи в обох центральних банках показали свою ефективність через кілька років. Але СЦБ довелося також подолати високий ризик суверенних дефолтів у країнах-учасниках $\mathrm{CC}$.

Процентна політика СЦБ по стабілізації фінансової системи та економіки і подальшого забезпечення стабільності цін була високо 
оцінена в світовому масштабі за свою високу ефективність. Тим не менш, 3 різних причин, багато заходів критикувалися вченими та політиками.

\section{Список використаних джерел}

1. European Parliament, European Parliament Research Service. Monetary Policy of the European Central Bank. Strategy, Conduct and Trends. In-depth analysis, February 2015

2. Cukierman, Alex. 2014. Euro-area and US banks behaviour, and ECB-FED monetary policies during the global financial crisis: a comparison. Financial Economics and International Macroeconomics. Centre for Economic Policy Research, December 2014

Клименко К. В. к.е.н., старший науковий співробітник ORCID ID: https://orcid.org/0000-0001-8295-1333

Савостьяненко М. В. старший науковий співробітник ORCID ID: https://orcid.org/0000-0002-6712-5831 ДННУ «Академія фінансового управління», м. Київ, Україна

\section{СТРАТЕГІЧНІ ОРІЕНТИРИ РОЗВИТКУ СПІВРОБІТНИЦТВА УКРАЇНИ З СВРОПЕЙСЬКИМ ІНВЕСТИЦЙНИМ БАНКОМ}

Україна співпрацює з Свропейським інвестиційним банком (СІБ) з 2004 р. За період співпраці Банк профінансував в Україні 62 проекти на загальну суму 5,86 млрд євро. Зокрема, 15 проектів на суму 3,217 млрд євро нині впроваджуються у державному секторі в сфері енергетики, транспорту, муніципальній інфраструктурі, розвитку малого та середнього бізнесу та в освіті [1].

Одним 3 перспективних напрямів інвестування СІБ в Україні $є$ впровадження енергоефективних та «зелених» проектів. Це відповідає Енергетичній стратегії України на період до 2035 року та співпадає із 
загальною тенденцією щодо фінансування зеленої економіки в Україні 3 боку інших провідних міжнародних фінансових інституцій та регіональних банків розвитку.

Слід зазначити, що розвиток співробітництва 3 ЄІБ, не підкріплено стратегічним документом щодо взаємної співпраці, як це реалізується у двосторонніх стосунках України з основними МФО.

Прийняття скоординованої, виваженої Стратегії співробітництва з ЄІБ в Україні на середньострокову перспективу, яка визначатиме пріоритетні напрями їх співпраці та операційні цілі. Це сприятиме плановому, поступовому, ефективному розвитку двосторонніх відносин з урахуванням реформаторських пріоритетів економічного розвитку в Україні.

Така Стратегія, на наш погляд, може мати таку структуру [2]:

1) Розділ щодо огляду діяльності Банку за попередні періоди та поточний інвестиційний портфель із змістовним аналізом впливу кредитно-інвестиційної діяльності СІБ на процес реформування економіки за весь період співпраці з Україною.

2) Оцінка поточного операційного середовища, де буде проаналізовано активні чинники і ключові умови проведення реформ в Україні.

3) Стратегічні напрями та пріоритети операційної діяльності на період реалізації Стратегії, в т. ч. в контексті запобіганням ризикам дестабілізації національної економіки.

4) Співробітництво ЄІБ із іншими МФО й донорами 3 оцінкою його потенційного кумулятивного ефекту.

5) Інструменти й механізми реалізації співпраці з СІБ. Тут мають бути конкретизовані форми кредитів, можливості отримання пільг, зокрема в рамках Свропейського інструменту сусідства та партнерства, 
розвиток і поглиблення механізмів подальшого співробітництва в межах програми «Східне партнерство», стимулювання прямих іноземних інвестицій тощо.

\section{Список використаних джерел}

1. European Investment Bank [Електронний ресурс]. - Режим доступу: https://www.eib.org/en/

2. Іванов С. М. Унормування співробітництва 3 МФО в контексті запобігання дестабілізації національної економіки / С. М. Іванов, К. В. Клименко, М. В. Савостьяненко // Фінанси України. 2018. - № 5. - C. 41-55.

Мішенко В. I.

д.e.н., nрофесор

ORCID ID: https://orcid.org/0000-0002-8565-2686

Льон І. М.

аспірант

ДВНЗ «Університет банківської справи», м. Київ, Україна

\section{ПРОЦЕНТНА ПОЛІТИКА: КЛЮЧОВІ НАПРЯМИ \\ ВДОСКОНАЛЕННЯ}

Аналіз практики використання центральними банками монетарних інструментів свідчить про те, що серед них відсутні такі, які 6 безпосередньо впливали на стимулювання економічного зростання. Опосередкований вплив може здійснюватися на основі використання операцій РЕПО, стимулювання кредитування економіки реалізації процентної політики.

Ключовими напрямами впливу центрального банку на економічне зростання в контексті посилення інституційних засад управління процесом монетизації та стимулювання економічного зростання є розроблення адекватної економічним умовам процентної 
політики та реалізація системи антиінфляційних заходів на основі використання монетарного режиму таргетування інфляції, який сприяє посиленню дії всіх каналів монетарного трансмісійного механізму [1, c. $24 ; 2$, c. 27].

У межах цих напрямів конкретними заходами щодо підвищення інституційної спроможності управління монетизацією економіки та стимулювання економіки повинні бути:

- підвищення рівня транспарентності монетарної політики та розширення комунікацій з широким колом громадськості [3, с. 21];

- актуалізація Стратегії монетарної політики 3 урахуванням особливостей сучасного етапу розвитку економіки, що пов'язані 3 нестабільністю на фінансових ринках;

- встановлення в межах нового дизайну монетарної політики як операційного орієнтира двотижневих операцій 3 рефінансування банків і відмова від симетричного коридору процентних ставок;

- зниження ставок за депозитними сертифікатами НБУ та встановлення їх на рівні ставки міжбанківського ринку мінус 7-10 п. п.;

- періодичний перегляд i уточнення операційного дизайну монетарної політики 3 метою посилення механізмів трансмісії ключової процентної ставки [3, с. 22];

- зниження рівня інфляційного таргету до $3 \pm 1$ п. п. і встановлення його спільним рішенням НБУ та Кабінету Міністрів.

\section{Список використаних джерел}

1. Міщенко В.I. Методологічні та методичні проблеми запровадження таргетування інфляції / B.I. Міщенко // Вісник Національного банку України. - 2006. - №5. - С.22-32.

2. Гнучкий режим курсоутворення: етапи запровадження та можливі наслідки для економічного розвитку України. Вип.15. - Київ: Національний банк України, 2010. - 124 с. 
3. Науменкова С.В. Влияние устойчивости денежного обращения на экономический рост / С.В. Науменкова, С.В. Мищенко // Известия Санкт-Петербургского государственного экономического университета. - 2013. - №3. - С.14-23.

Науменкова С. B.

d.e.н., nрофесор

Київський національний університет імені Тараса Шевченка, м. Київ, Україна

ORCID ID: https://orcid.org/0000-0001-8582-6044

\section{МОНЕТАРНА ТА БЮДЖЕТНА ПОЛІТИКА УКРАЇНИ: ЕТАПИ} ВЗАСМОДІї

В умовах відкритої економіки ключовим питанням стимулювання економічного зростання $є$ характер взаємодії монетарної політики центрального банку та бюджетної політики уряду, які повинні грунтуватися на механізмах їх тісної взаємодії та координації [1, с. 169].

Проведений аналіз за 2000-2018 pр. дозволив виокремити в монетарній та бюджетній політиці в Україні три етапи: 2000-2008 pp. стимулююча монетарна політика та жорстка бюджетна політика; 20092013 рр. - помірно стимулюючі як монетарна, так і бюджетна політика; 2014-2017 pp. - жорстка монетарна (монетарний утиск) та жорстка бюджетна політика (фіскальне домінування) [2, с. 367].

Перший етап характеризувався високими темпами приросту грошової маси, зниженням ключової ставки центрального банку, низьким дефіцитом державного бюджету та державного боргу, що забезпечувало високі темпи приросту реального ВВП. 
Для другого етапу характерним був помірний проріст бази та грошової маси, поступове збільшення дефіциту бюджету та державного , що в 2012-2013 рр. призвело до економічної рецесії.

Третій етап характеризувався підвищенням ключової ставки, зниженням рівня монетизації економіки, уповільненням темпів кредитування та збільшенням державного боргу, що посилило інфляційні процеси та уповільнило економічне зростання.

Сучасні наукові дослідження свідчать про те, що реалізація монетарної та бюджетної політики має грунтуватися на принципах поєднання їх протилежної дії, тобто, в разі проведення жорсткої монетарної політики бюджетна політика повинна бути стимулюючою i, навпаки. Однак, в Україні упродовж аналізованого періоду така ситуація спостерігалась лише в 2001-2008 pp. [3, с. 54].

Проведене дослідження свідчить про те, що реалізація ефективної економічної політики держави 3 метою сприяння економічному зростанню та забезпеченню макроекономічної стабільності повинна грунтуватися на тісній координації монетарної та бюджетної політики.

\section{Список використаних джерел}

1. Науменкова С.В. Влияние денежно-кредитной политики центрального банка на стимулирование экономического роста / С.В. Науменкова, В.И. Мищенко // Проблемы современной экономики. 2015. - №54. - С.168-174.

2. Міщенко С.В. Монетарні цикли в економіці України / С.В. Міщенко, С.В. Науменкова, I.М. Льон // Актуальні проблеми економіки. - 2016. - №11. - С. 363-372.

3. Науменкова С.В. Обстеження збалансованості попиту та пропозиції на кредитному ринку: досвід центральних банків / С.В. Науменкова // Вісник університету імені Тараса Шевченка. Серія: Економіка. - 2014. - №10(163). - С.51-57. 
Нежива М. О.

к. е. н, старший викладач

Київський національний торговельно-економічний університет,

м. Київ, Украӥна

ORCID ID: https://orcid.org/0000-0002-3008-5338

\section{КРЕАТИВНА ЕКОНОМІКА - КЛЮЧОВИЙ ВЕКТОР РОЗВИТКУ ДЕРЖАВИ}

Креативність є ключовим вектором для суспільства, яке базується на знаннях та економіці, що робить свій внесок у політику, бізнес, культуру, мистецтво, а також в усі сфери суспільного життя, питання розвитку креативних індустрій є вкрай важливим та нагальним. Креативні індустрії впливають на формування доходів бюджету, створення додаткових робочих місць, експортні надходження, інвестиційну привабливість, розвиток інтелектуального капіталу.

3 ціллю реагування на культурні, економічні, соціальні та технологічні зрушення, людству вкрай необхідні нові стратегії розвитку. У цьому контексті на перший план виходить концепт «креативної економіки». Термін «креативна економіка» почав активно вживатися у час, коли класичне мистецтво почало активно взаємодіяти 3 такими сучасними напрямами як реклама, дизайн, мода та стало доступним під впливом діджитал-технологій. За даними ООН на частку креативної економіки припадає 3,4\% світового ВВП, що становить майже 1,6 трлн. дол. США й удвічі перевищує обсяги щорічних надходжень від міжнародного туризму. Щорічні темпи зростання у різних країнах варіюють від 4,3\% до 17,6\%, удвічі перевищуючи темпи зростання сфери послуг 
і в чотири рази перевищуючи темпи зростання сфери промислового виробництва. При цьому частка зайнятих у креативній економіці досягла 25\% населення світу [1].

Однією з найголовніших відмінностей креативної економіки від інших галузей є наявність, окрім мінової та споживчої, виразної вартості, що являє собою міру культурної значимості та іноді може не мати відношення до вартості виготовлення або рівня корисності (наприклад, речі високої моди, фільми-бестселери). Основні умови розвитку креативної економіки: політичне середовище (інтелектуальна власність, фінансування, держава як клієнт, міста та кластери, освіта та навички) та бізнес середовище (профіль креативних індустрій, інноваційні шляхи роботи).

Таким чином, глобальний ринок креативних індустрій розвивається досить стрімко та мобільно, що вимагає від окремих країн та виробників високих адаптаційних здібностей, щоб відповідати світовим тенденціям. Україна має значний потенціал розвитку креативного сектору економіки. Для подолання структурних нерівномірностей в галузі креативних індустрій необхідно сприяти виявленню креативного потенціалу та сприяти реалізації започаткованих інновацій. У той же час, індивідуальна та колективна ініціатива має бути підтримана виваженою і системною політикою.

\section{Список використаних джерел}

1. Creative And Cultural Economy Series British Council. [Електронний ресурс]. https://joomla.abstract.bg/creative_and_cultural_economy_series_british_c ouncil.pdf 
Київський національний торговельно-економічний університет, м. Київ, Україна ORCID ID: http://orcid.org/0000-0001-8433-1939

\section{РОЗВИТОК ВІТЧИЗНЯНОГО РИНКУ КРЕДИТНИХ ПОСЛУГ}

В умовах сучасного розвитку ринку кредитних послуг в Україні $\epsilon$ одним із швидко зростаючих сегментів вітчизняної кредитної системи, розвиток якої супроводжується дисбалансами в економіці, зміною архітектурної структури фінансового ринку та політичною ситуацією в країні. Зазначимо, що кредитна активність є базовим елементом стабільності економіки країни, що визначає необхідність оцінки цього процесу в єдності та розходженні двох його сторін, кожна 3 яких являє собою відносно самостійні сегменти ринку кредитних послуг. 3 одного боку, це ринок пропозиції грошей у кредит, з іншого боку - ринок попиту (запозичення, залучення коштів на борговій основі). У цьому зв'язку спряженість активності й стабільності ринку кредитних послуг грунтується на розвиненості в цьому напрямі учасників кредитування та запозичення в їхній взаємозалежності як інститутів боргових відносин.

Зауважимо, що ринок кредитних послуг - це специфічний вид ринку, на якому купуються і продаються кредитні ресурси та банківські послуги [1, с. 147], регулюється ринковими законами господарювання, що формують в остаточному підсумку його сутність, тобто зв’ язки та відносини як усередині самого ринку, так і у взаємодії з іншими економічними категоріями. 
На сьогодні в Україні основними кредиторами є банки та небанківські фінансово-кредитні установи (далі НФКУ), серед яких спостерігаються тенденції збільшення конкуренції.

Слід зазначити, що аналізуючи динаміку інституцій на ринку кредитних послуг за останні роки видно, що кількість НФКУ значно переважає кількість банків. У розвинутих країнах світу така тенденція свідчила б про високий рівень розвитку небанківського сектору країни, але в Україні обсяг кредитних портфелів цих установ $є$ надто меншими у порівнянні з банками. Обсяг кредитного портфелю НФКУ за 2018 рік в 6,5 разів менше в порівнянні з розміром кредитного портфелю банків в Україні. Зрозуміло, що витримувати конкуренцію на ринку кредитних послуг НФКУ практично неможливо, їх частка кредитного портфелю на ринку склала 13,1\% (84532,7 млн. грн.), не зважаючи на складну економіко-політичною ситуацією в країні, а 86,9\% кредитного портфелю належать банкам [2, 3].

Зростання сектору небанківського ринку кредитних послуг має позитивний вплив, оскільки обмежує монопольне становище банків на ньому. Наявність тенденції перерозподілу частини фінансових ресурсів з банківського сектору у сектор небанківських установ свідчить про формування передумов для переорієнтації вітчизняної моделі ринку кредитних послуг з банкоцентричної на ринкову

\section{Список використаних джерел}

1. Сич С.М. Ринок фінансових послуг [текст] : навчальний посібник / С.М. Сич, В.П. Ільчук, Н.І. Гавриленко. - К.: «Центр учбової літератури», 2012. - 428 с.

2. Офіційний сайт Національного банку України [Електронний pecypc]. - Режим доступу : http://www.bank.gov.ua.

3. Офіційний сайт Національної комісії 3 державного регулювання у сфері ринків фінансових послуг [Електронний ресурс]. - Режим доступу: http://www.dfp.gov.ua 
Циганова Н. В.

к.е.н., доиент

Київський начіональний економічний університет

імені Вадима Гетьмана,

м. Київ, Україна

ORCID ID: http://orcid.org/0000-0002-5186-8884

\section{РЕСУРСНЕ ЗАБЕЗПЕЧЕННЯ ДІЯЛЬНОСТІ БАНКІВ В УМОВАХ ЦИКЛІЧНОСТІ ЕКОНОМІЧНОГО РОЗВИТКУ}

Функціонування бізнесу в ринкових умовах передбачає стратегічну орієнтацію на забезпечення стабільного розвитку, тобто оптимальне поєднання ефективного використання ресурсів, розширення присутності на ринку, стійкості до зовнішніх шоків, зростання вартості підприємства. Проте в умовах циклічності економічного розвитку бізнес-цілі мають узгоджуватися 3 макроекономічними тенденціями. Тому циклічне зростання економіки формує сприятливі умови для розширення бізнесу та зростання попиту на кредитні ресурси. Фінансові ринки розширюють грошову пропозицію, що прискорює циклічне зростання та інноваційне оновлення економіки. Для циклічного нарощування кредитної діяльності в одній частині економічного циклу або ії звуження в іншій у розпорядженні банків має бути ресурсна база, гнучка до відповідних циклічних коливань попиту на грошовому ринку.

Вітчизняні й зарубіжні науковці достатньо уваги приділяють формуванню ресурсного забезпечення діяльності банків, проте їх напрацювання переважно спрямовані на генерування рекомендацій щодо стійкого зростання кількісних параметрів ресурсного забезпечення та покращання якісних показників. 
Однак надлишок ресурсів в умовах обмеження ділової активності підприємств в умовах циклічного спаду спричиняє ряд проблем у діяльності банків, зокрема зниження прибутковості через обмежені можливості кредитного використання коштів та надлишкові резерви, зростання ризиків банківської діяльності внаслідок розширення операцій спекулятивного характеру тощо. Отже ресурси банків мають гнучко реагувати на циклічні зміни в економіці, як і грошова пропозиція. Частково звуження банківських ресурсів відбувається за рахунок зменшення прибутку банків в кризових умовах та рефінансування з боку центрального банку. Також на циклічні зміни зобов'язань банків впливає зменшення ділової активності бізнесу, що відповідно зменшує мультиплікацію депозитів.

Для виходу з циклічної кризи та наступної економічної депресії центральні банки традиційно застосовують політику кількісного пом'якшення, що передбачає зниження ключової ставки та зростання грошової пропозиції. Проте центральні банки формують лише грошову базу, а більша частина кредитних грошей формується саме комерційними банками в процесі кредитної діяльності. Так провідні фахівці 3 монетарного регулювання НБУ В. Лепушинський і С. Ніколайчук акцентують увагу на тому, що центральний банк впливає на пропозицію грошей через управління процентними ставками, а ресурсне забезпечення розширення банківського кредитування формують безпосередньо банківські установи [1]. Тобто в умовах зростання або зменшення попиту на кредитні ресурси спрацьовують важелі ринкового саморегулювання економіки і циклічні зміни обсягів ресурсного забезпечення - об'єктивне економічне явище. 


\section{Список використаних джерел}

1. Лепушинський В. Як створюються гроші і яка в цьому процесі роль Нацбанку / В. Лепушинський, С. Ніколайчук [Електронний pecypc]. - Режим доступу: https://voxukraine.org/uk/yak-stvoryuyutsyagroshi-i-yaka-v-tsomu-protsesi-rol-natsbanku-spojler-negolovna/?fbclid=IwAR23TyxDktWy3_fpaWkYzJSrUNhjV9Aney0TykaIe Hd82VXfds7h3mOqTYk

\section{Шимла Войтек}

к.е.н., ад'юнкт

Краківський економічний університет,

м. Краків, Польща

Колегович Конрад

к.е.н., ад’юнкт

Краківський економічний університет,

м. Краків, Польща

Познякова О. I.

старший викладач

Національний університет «Львівська політехніка»

м. Львів, Украӥна

\section{ЕФЕКТ ВИТІСНЕННЯ В КОНТЕКСТІ ПОЛІТИКИ ВНУТРІШНІХ}

\section{ЗАПОЗИЧЕНЬ УКРАЇНИ}

Аналізуючи вплив державного боргу на економічний ріст країни, важливо з'ясувати його взаємозв'язок 3 іншими економічними параметрами, зокрема з інвестиційною активністю приватного сектора. Щоб уникнути негативних наслідків підвищення відсоткових ставок як результату стимулюючої політики, уряд в Україні збільшує державні витрати, виходячи на ринок грошей. Однак згідно кейнсіанської моделі макроекономічної рівноваги, це також зумовлює зростання попиту на гроші, а внаслідок цього - й відсоткових ставок, що робить кредитні ресурси недоступними для приватного сектору економіки. Зв'язок між бюджетним дефіцитом, зростанням відсотковиї ставок та зниженням позикової активності приватного сектора відомий як ефект витіснення. 
Тому важливо зрозуміти, хто має значний вплив на економічну рівновагу у фінансовому секторі і де пересікаються інтереси держави та приватного сектора.

За останні десять років зовнішні та внутрішні запозичення України зросли з 316885 млрд. грн. у 2012році до 2171917 млрд. грн. лише у березні 2019 року.[1] Важливе значення в структурі даних запозичень займають Облігації внутрішньої державної позики (ОВДП). Відповідно до даних Національної комісією з цінних паперів та фондового ринку, обсяг торгів ОВДП у 2018 склав майже 95\% всіх торгів на фондовому ринку України. [2] Тому важливо проаналізувати, хто є основними внутрішніми кредиторами держави.

Таблиия 1

Зміна структури власників ОВДП за 2015-2019 роки, \%

\begin{tabular}{|r|c|c|c|c|}
\hline Станом на дату & $\begin{array}{c}\text { ОВДП у } \\
\text { власності НБу }\end{array}$ & $\begin{array}{c}\text { ОВДП у } \\
\text { власності } \\
\text { банків }\end{array}$ & $\begin{array}{c}\text { ОВДП у } \\
\text { власності інших } \\
\text { резидентів }\end{array}$ & $\begin{array}{c}\text { ОВДП у } \\
\text { власності } \\
\text { нерезидентів }\end{array}$ \\
\hline $1 / 1 / 2016$ & 77.19 & 16.15 & 2.22 & 4.45 \\
\hline $1 / 1 / 2017$ & 57.22 & 38.27 & 3.55 & 0.97 \\
\hline $1 / 1 / 2018$ & 45.32 & 48.72 & 4.16 & 1,8 \\
\hline $1 / 1 / 2019$ & 46.06 & 49.55 & 3.54 & 0,84 \\
\hline
\end{tabular}

Сформовано на основі [1]

Бачимо, що НБУ та комерційні банки є головними покупцями ОВДП в Україні. Зокрема частка ОВДП у власності банків суттєво зросла за останні 2 роки. Враховуючи, що банківська система України $€$ провідною ланкою фінансової системи України та головним кредитором приватного сектору в національній економіці, можна стверджувати про потенційне скорочення обсягів банківського кредитування [4]. Однак в Україні сформувалася державна монополія в банківському секторі, тому з огляду на боргову політику, банки перестають виконувати важливу роль кредитування та підтримки 
інвестиційних процесів в приватному секторі, стаючи заручниками фіскальної політики, що підтверджує ефект витіснення.

\section{Список використаних джерел}

1. Дані щодо Державного боргу України. [Електронний ресурс]. Режим доступу: https://index.minfin.com.ua/ua/finance/debtgov/

2. Офіційний веб-сайт НКЦПФР. [Електронний ресурс]. Режим доступу: https://www.nssmc.gov.ua/2019/02/14/nktspfr-ogoloshupokazniki-fondovogo-rinku-za-2018-rk/

3. Шпигоцька Н. Ефект витіснення та його вплив на масштаби кредитування економіки банківською системою України / Світ фінансів. - 2015. - №2. - С.61-71

4. Кучеренко В., Данкевич Р., Тринчук В. Форми інтеграції банківського і страхового капіталу: монографія. Львів: Видавництво «ГАЛИЧ-ПРЕС». - 2018, 284c. [Електронний ресурс]. - Режим доступу: https://www.twirpx.com/file/2573808/

5. Клапків Ю. Стратегічні альянси як прояв інтеграції страхової та банківської сфери: зарубіжний досвід та перспективи формування в Україні/ Світ фінансів. - 2017 - №5. - С.177-182.

\section{СЕКЦІЯ 2}

\section{ЗАХИСНА ТА ПРЕВЕНТИВНА СИСТЕМИ РЕГУЛЮВАННЯ ДІЯЛЬНОСТІ ФІНАНСОВИХ УСТАНОВ В УМОВАХ ЗМІНИ ДІЛОВИХ ЦИкЛІв}

Белянко Л. Л. асистент Київський наиіональний торговельно-економічний університет м. Київ, Україна ORCID ID: https://orcid.org/0000-0001-9986-261X

\section{СТРЕС-ТЕСТУВАННЯ БАНКІВ ТА ЙОГО РОЛЬ У ФОРМУВАННІ ДІЛОВОЇ АКТИВНОСТІ КРАЇНИ}

Фінансові кризи, які зароджується в одній країні, не тільки змушують окремі банки регіону визнати банкрутство, але й неодмінно відображаються на економічній кон юнктурі інших країн, банківський 
сектор яких відкритий для чисельних ризиків. Необхідність проведення стрес-тестування банків формується під впливом постійно зростаючих глобалізаційних процесів у світовій економіці та виступає важливим індикатором їх фінансової стабільності і спроможності забезпечити максимальну готовність до шокових умов. Стрестестування має величезне значення для розвитку економіки країни та формування іiі ділової активності, що виражається у наступному.

По-перше, підтримка довіри до банків. Стрес-тести неодмінно підвищують довіру до банків зі сторони бізнесу та населення, адже його результати активно використовують економісти та аналітики у різного роду економічних звітах, що забезпечує обізнаність перших стосовно фінансового становища банківського сектору.

По-друге, підвищення інвестиційної привабливості країни та прискорення процесу капіталізації банківського сектору. Стрес-тести здатні показати, що якщо банківська система чи окремий банк зможуть протистояти різноманітним шокам, то вони будуть виглядати привабливо як для клієнтів, так і для потенційних інвесторів. Для ринку це вагомий аргумент у бік низької вірогідності повторних кризових явищ, а для інвесторів - інвестиційної привабливості країни. Це, в свою чергу, спонукає останніх до активних дій щодо збільшення потоку власного капіталу у фінансовий сектор, підвищується капіталізація банківського сектору країни, що прискорює її розвиток.

По-третє, забезпечення бізнесу достовірною прогнозною інформацією. Стрес-тестування - вкрай цінний інструмент прогнозування. Слід зазначити, що його результати показують ступінь вразливості банківського сектору до процесу економічного спаду в країні та до коливань різноманітних економічних змінних, таких як відсоткові ставки, рівень безробіття, ріст ВВП тощо. Як правило, стрес- 
тести проводяться за трьома, іноді двома, сценаріями, в яких закладено найбільш чіткі прогнози щодо зміни макроекономічних факторів. А це дуже актуальні дані та припущення щодо, наприклад, рівня ринкових відсоткових ставок чи обмінних курсів валют, які використовуються при плануванні та веденні бізнесу в країні.

По-четверте, постійне удосконалення механізму функціонування банківської системи. Часто стрес-тестування, як важливий інструмент управління ризиками, надає змогу наглядовим органам країни, так само як і банкам, визначити вразливі місця своєї діяльності. Це спонукає до вдосконалення методичних засад проведення стрес-тестів зі сторони центрального банку, що може зачіпати й інші сторони діяльності банків, зазнає оновлення банківська система країни, постійно удосконалюється механізм іiі функціонування. Це слугує хорошим сигналом фінансової стабільності у країні та спонукає бізнес до активного капіталовкладення. Крім того, стрес-тестування у певному розумінні «очищує» банківську систему країни, створюються передумови для припинення діяльності слабких банків.

Верезубова T. A., д.е.н., професор Косякова А. А., студент Білоруський державний економічний університет м. Мінськ, Беларусь

\section{SOLVENCY II - ЗАХИСНА СИСТЕМА РЕГУЛЮВАННЯ ДІЯЛЬНОСТІ СТРАХОВИХ ОРГАНІЗАЦІЙ}

Розвиток сучасного страхового ринку може здійснюватися тільки при наявності надійних, фінансово стійких страхових організацій. 
Багато країн працюють ще з 2000 років над вдосконаленням системи контролю платоспроможності страховиків шляхом розробки i впровадження об'єктивних показників їх поточного фінансового стану [1], [2]. В Євросоюзі з 2016 року здійснено перехід до ризикорієнтованого підходу щодо регулювання страхового ринку, вступила в силу директива Solvency II. Ïї метою є встановлення єдиної системи нормативно-правового управління ризиками та забезпечення достатності капіталу страхових організацій, що гарантує захист страхувальників при настанні страхових випадків.

Структура Solvency II передбачає тристоронній контроль: за оцінкою ризиків і визначення вимог до власного капіталу, за системою внутрішнього управління страховиком, за розкриттям інформації про ризики, власні кошти і інших найважливіших даних перед регулюючої установою і громадськістю. Основними показниками, що підлягають пруденційному нагляду, є мінімальний капітал (MCR) і нормативний капітал (SCR). MCR щоквартально i досить просто визначає необхідний рівень власних коштів страхової організації, що дозволяє виконувати зобов'язання протягом року 3 імовірністю $85 \%$. SCR враховує всі види ризиків (кредитні, ринкові, операційні та страхові) i повинен забезпечувати платоспроможність протягом року у разі несподіваних значних втрат з ймовірністю 99,5\%. Він визначається щорічно за допомогою складних обчислень, наголос зроблений на застосування математичних методів. Активно використовується актуарна математика, розрахунки на основі стохастичних моделей.

Впровадження стандартів Solvency II вимагає значної перебудови внутрішніх систем і процесів, підвищення кваліфікації і збільшення обсягу роботи персоналу, зростання витрат страхових організацій [3]. Однак впровадження нової системи контролю платоспроможності 
страховиків покликане підвищити їх фінансову стабільність, уніфікувати правила управління i функціонування страхових організацій, поліпшити якість нагляду і регулювання, підвищити прозорість у страховому секторі, зміцнити довіру до нього інвесторів і в кінцевому рахунку поліпшити захист прав страхувальників. Дана робота підготовлена за підтримки Білоруського республіканського фонду фундаментальних досліджень.

\section{Список використаних джерел}

1. Pukala R. Czy wymagają ubezpieczyciele Solvensy II (Polska) / Usługi finansowe. - 2012. - № 5 (95). - S. 38-40.

2. Тринчук В.В. Перспективи розвитку страхового ринку у зв’язку зі вступом України до СОТ / Страхова справа. - 2005. - №3. C.46-56.

3. Верезубова Т.А. Финансовая стратегия страховых организаций в условиях развития национальной экономики. - Минск : Белорус. гос. экон. ун-т, 2015. - 185 с.

Гербич Л. А. к.е.н., дочент Київський національний торговельно-економічний університет м. Київ, Україна ORCID ID: http://orcid.org/0000-0002-3560-5777

\section{ДЕТЕРМІНАНТИ ПРЕВЕНТИВНОГО АНТИКРИЗОВОГО УПРАВЛІННЯ БАНКОМ}

В умовах нестабільності розвитку банківської системи України все більше зростає роль антикризового управління в його діяльності, особливо превентивного. Останнє повинне бути спрямоване на недопущення або запобігання виникненню кризового стану банку.

Одними 3 перших складових превентивного антикризового управління $є$ моніторинг фінансового стану банку та діагностика 
ймовірності настання кризи. На будь-якому етапі життєвого циклу банку на постійній основі повинен проводитись моніторинг ключових груп показників діяльності банку, зокрема, ліквідності, достатності капіталу, ділової активності та інших. Виявлення найменших відхилень від нормативних або допустимих значень цих показників повинне стати сигналом до запровадження антикризових заходів.

Також обов'язковою складовою превентивного антикризового управління є періодична діагностика ймовірності настання кризи, яку слід здійснювати за допомогою моделей попереджуючих індикаторів кризи, до яких, на думку Ребрик Ю.С., належать сигнальний підхід; моделі дискретного вибору; розрахунок прогнозного індикатора кризи на основі використання теорії нечіткої логіки; визначення глибини банківської кризи та прогнозування банкрутства. Також до них слід додати різні методи стрес-тестування, зокрема, тести чутливості, сценаріїв та екстремальних величин. Кожен з цих методів має свої переваги та недоліки і вибір конкретного залежить від трудомісткості застосування, точності розрахунків, кваліфікації працівників банку.

Важливою складовою превентивного антикризового управління банком є постійне застосування різноманітних методів управління ризиками, до яких відносяться резервування, зокрема, динамічне, лімітування, хеджування, диверсифікація, сек'юритизація, страхування та інші.

Ще однією складовою успішного превентивного антикризового управління банком $є$ проведення постійних маркетингових досліджень та вчасна переорієнтація продуктової та клієнтської стратегії банку на більш перспективні види діяльності, ринки збуту тощо.

Застосування перелічених складових превентивного антикризового управління банком дозволяє йому вчасно 
ідентифікувати загрозу та ймовірність виникнення кризи, створити необхідні «подушки безпеки» та переорієнтувати діяльність, що, в свою чергу, забезпечує зниження та запобігання втрат від настання несприятливих ситуацій для банку i, як результат, стабільне становище банку на ринку.

\section{Список використаних джерел}

1. Ребрик Ю.С. Особливості сучасних підходів до діагностики кризових явищ у банку / Ю.С. Ребрик // Формування ринкових відносин в Україні. - 2012. - № 12(139). - С. 117-122.

Гнатченко Д. Д. асистент

Київський національний торговельно-економічний університет, м. Київ, Україна ORCID ID: http://orcid.org/0000-0002-6584-4525

\section{КІБЕРБЕЗПЕКА БАНКІВСЬКОЇ СИСТЕМИ УКРАЇНИ}

В останні роки ситуація, що склалася в Україні у сфері кібербезпеки вкрай складна, збільшилася кількість кібернетичних атак на інформаційні ресурси держави. В червні 2017 року Україна зазнала кібератаки вірусом «Реtya.A», який завдав шкоди майже на півмільярда доларів. Кібератака вивела 3 ладу велику кількість об'єктів, таких як: Укрзалізниця, міжнародні аеропорти «Київ» і «Бориспіль», Укрпошта, Київський метрополітен, Чорнобильська атомна електростанція, банківські установи «Ощадбанк» $\mathrm{i}$ «Укргазбанк», тому питання кіберзахисту банківської системи та і всієї країни в цілому вкрай важливе.

В умовах значної залежності банківської діяльності від надійності інформаційних технологій, які вона використовує, забезпечення інформаційної безпеки стає однією з фундаментальних 
засад існування банківської системи взагалі. Відповідно до Закону України «Про Національний банк України» [1], Національний банк України (НБУ): визначає напрями розвитку сучасних електронних банківських технологій; створює та забезпечує надійне та ефективне функціонування, розвиток створених ним платіжних та облікових систем; встановлює для банків правила захисту інформації; контролює створення платіжних інструментів, систем автоматизації банківської діяльності та засобів захисту банківської інформації; визначає порядок, вимоги та заходи із забезпечення кіберзахисту та інформаційної безпеки у банківській системі України, та здійснює контроль за їх виконанням.

3 метою запровадження правового механізму з урахуванням міжнародних стандартів 3 питань інформаційної безпеки, загальноприйнятих у міжнародній практиці принципів забезпечення інформаційної безпеки і кіберзахисту було прийнято положення [2], яке встановлює: вимоги до інформаційних систем банку, що взаємодіють $з$ інформаційними системами НБУ, 3 урахуванням напрямів розвитку криптографічного захисту інформації в інформаційних системах Національного банку; обов'язкові мінімальні вимоги щодо організації заходів із забезпечення інформаційної безпеки та кіберзахисту; принципи управління інформаційною безпекою.

Надійне функціонування банківської системи їі захищеність від потенційних кібератак $\epsilon$ важливою складовою держави. Тому актуальним $є$ питання кіберзахисту банківської системи України, визначити основні напрями протидії кіберзлочинам, урегулюванню взаємовідносин між державними органами і приватними організаціями та закріплення його на законодавчому рівні. 


\section{Список використаних джерел}

1. Закон України «Про Національний банк України» // Відомості Верховної Ради України (ВВР). - 1999. - № 29. - 238 с.

2. Положення про організацію заходів із забезпечення інформаційної безпеки в банківській системі України, затверджене Постановою Правління Національного банку України 28.09.2017 № 95.

Городянська Л. В.

к.е. н., доцент

Військовий інститут Київського начіонального університету імені Тараса Шевченка,

м. Київ, Україна

ORCID ID: http://orcid.org/0000-0002-4482-1690

Носенко Т. I.,

к. е. н., дочент

Київський університет імені Бориса Грінченка, м. Київ, Украӥна

\section{БЕЗПЕКА БАНКІВСЬКОЇ СИСТЕМИ УКРАЇНИ}

Банківська система $є$ сукупністю різних видів національних банків і кредитних установ, що діють в рамках загального грошовокредитного механізму. Вплив глобальних процесів на економіку України та їі банківську систему потребує заходів, що сприятимуть забезпеченню економічної безпеки іiі розрахункового і платіжного механізмів. Незалежно від економічної системи держави, їі банківська система відіграє особливу роль як невід`ємна складова механізму національної економіки. Основним критерієм безпеки банківської діяльності є стабільність фінансового стану національних банків і кредитних установ держави. Немає єдиної думки стосовно видів ризиків і тлумачення іiї сутності, які $є$ недостатньо обгрунтованими, або не враховують природу безпеки банківської установи, інтереси власників, керівництва, персоналу і клієнтів банківської установи, а також види потенційних загроз. Слушною є думка С. Яременко, який 
виокремлює два підходи щодо визначення поняття «безпека банків». Один підхід враховує поняття «загрози», інший - враховує досягнення мети банківської діяльності.

Метою дослідження є визначення підходів та напрямів безпеки банківської системи в умовах інтеграції економіки України у світове господарство.

Для забезпечення безпеки банкам потрібно створення певної системи, яка дозволяє на постійній основі здійснювати діагностичні і превентивні заходи, спрямовані на підтримку належного рівня безпеки. 3 врахуванням досвіду розвинених країн, відповідно до резолюції 57/239 Генеральної Асамблеї ООН «Елементи для створення глобальної культури кібербезпеки» [1], глобальна кіберкультура вимагає від усіх учасників врахування певної сукупності елементів. В Україні банківська діяльність грунтується на Законі України «Про банки і банківську діяльність» [2]. Особливо актуальним питання безпеки $є$ для банківської системи України, оскільки процеси глобалізації та інтеграції впливають на іï економічну систему загалом та іï складову - банківську систему. Вітчизняна банківська система $€$ сектором економіки та фінансового ринку, де відбувається понад 90 \% фінансових послуг в Україні. Питання безпеки банків є важливими як для банків, так і для усіх учасників ринкових відносин. Зазначеним питанням приділяють увагу власники банку та його акціонери, яких турбує розвиток власного бізнесу, матеріальна, моральна та соціальна відповідальність. Безпека банків також турбує клієнтів і партнерів. Таким чином, безпека банків повинна враховувати ризики та забезпечувати безпеку банку як організації, безпеку банківського персоналу, безпеку банківських операцій тощо. 
Проблема безпеки банківської системи, на нашу думку, є комплексною. Пропонується іiї розв'язання за такими напрямами:

- профілактика та запобігання правопорушенням і злочинним посяганням на власність, персонал та імідж банку;

- своєчасне виявлення реальних і потенційних загроз банку, проведення заходів щодо їх нейтралізації;

- оперативне виявлення змін і негативних тенденцій у сферах діяльності, інтересів та інформаційної уваги банку, своєчасне реагування елементів його структури на них;

- виявлення та формування умов, сприятливих для реалізації банком своїх інтересів;

- виховання та навчання персоналу банку з питань безпеки;

- послаблення шкідливих наслідків від дій конкурентів або злочинців з підриву безпеки банку;

- аналіз та забезпечення достатнього рівня ресурсів та капіталу, зростання прибутку, недопущення банкрутства;

- збереження і ефективне використання фінансових, матеріальних та інформаційних ресурсів банку.

Вважаємо, що країна має гарантувати безпеку та ефективність платіжних систем, здійснювати контроль за належним формуванням банківської безпеки та сприяти недопущенню або припиненню протиправних i кримінальних дій, таких як шахрайство, злам електронних систем, крадіжка грошей і документів, розбій та ін. Банківська установа має враховувати ризики зовнішнього та внутрішнього середовища та проводити аналіз ризиків банківських операцій (активних, пасивних, кредитних, із цінними паперами, на міжбанківському ринку тощо) і планувати шляхи їх зниження (ризикменеджмент). Вплив внутрішнього середовища зумовлює виникнення 
загроз, які можуть перешкоджати процесу реалізації стратегічних напрямків розвитку банків з точки зору прибутковості та мінімізації ризиковості. Загалом, банківська установа має визначити цілі, підходи й завдання та сформувати чіткий механізм задля забезпечення належного рівня економічної безпеки. Важливе значення в безпеці банку є дотримання банківської таємниці - обов'язок банку зберігати у таємниці особисті дані клієнта, стан їх рахунків і виконувані ними фінансові операції.

Отже, формування системи безпеки банківських установ $є$ комплексною проблемою, вирішення якої потребує формування напрямів і завдань, які визначає банк на кожному окремому етапі його розвитку. Обсяг завдань економічної безпеки потребує системного підходу та врахування внутрішніх та зовнішніх факторів у певному часовому інтервалі.

Список використаних джерел

1. Элементы для создания глобальной культуры кибербезопасности, Утвержденные резолюцией 57/239 Генеральной Ассамблеи $\mathrm{OOH}$ от 20 декабря 2002 года https://zakon.rada.gov.ua/laws/show/995_b42

2. Про банки і банківську діяльність: Закон України від 07.12.2000 №2121-III [Електронний ресурс] - Режим доступу: http://zakon.rada.gov.ua - назва $з$ титул. екрана.

Еркес О. С. к.е.н., доиент

Київсьий національний торговельно-економічний університет, м. Київ, Україна ORCID ID: http://orcid.org/0000-0002-1746-590X НОРМАТИВ ЛІКВІДНОСТІ NSFR: МЕТОДИКА ВИЗНАЧЕННЯ

Відповідно до рекомендацій Базельського комітету в Україні триває процес запровадження нового етапу вдосконалення системи 
управління ризиком банківської ліквідності, метою якого є підвищення стійкості банків до короткострокових $\mathrm{i}$ довгострокових шоків ліквідності та наближення вітчизняного банківського регулювання до європейських стандартів. Цей процес відбувається поступово: запровадження нормативу LCR (з 2018 року) і розробка, тестування та імплементація нормативу NSFR (2018-2020 роки).

Норматив NSFR (Net Stable Funding Ratio) - це коефіцієнт чистого стабільного фінансування, що відображає достатність довгострокової ліквідності у банку. Ключовою ціллю є поглинання шоків ліквідності на горизонті понад рік шляхом зменшення невідповідності між строками активів та пасивів.

B країнах Свропи норматив NSFR запроваджений з 2018 року. Розробка NSFR в Україні ще триває. Запровадження NSFR у діяльність вітчизняних банків заплановане на 2020 рік. Очікується тривалий період застосування нормативу в тестовому режимі.

Коефіцієнт чистого стабільного фінансування (NSFR) розраховується як співвідношення між обсягом наявного стабільного фондування, який розраховується на основі структури ресурсної бази банку в залежності від іiі виду та терміновості із застосуванням так званих коефіцієнтів наявного стабільного фондування, та обсягом необхідного стабільного фондування, що визначається в залежності від структури активів і позабалансових зобов'язань банку із застосуванням коефіцієнтів необхідного стабільного фондування:

$$
\begin{aligned}
& \text { NSFR }=\frac{\text { Обсяг наявного стабільного фондування (ASF) }}{\text { Обсяг необхідного стабільного фондування (RSF) }}= \\
& \geq 100 \%
\end{aligned}
$$

Для розрахунку NSFR всім категоріям активів банків присвоюється різна питома вага, що дозволяє визначити потреби в забезпеченні за рахунок стабільних джерел фондування (табл.1). 


\section{Питома вага активів банку для розрахунку нормативу NSFR}

\begin{tabular}{|c|c|c|c|}
\hline $\begin{array}{c}\text { Наявна сума стабільного } \\
\text { фондування (ASF) }\end{array}$ & Коефіцієнт & $\begin{array}{c}\text { Необхідна сума } \\
\text { стабільного фондування } \\
\text { (RSF) }\end{array}$ & Коефіцієнт \\
\hline Капітал & \multirow{2}{*}{$100 \%$} & $\begin{array}{l}\text { Готівкові кошти } \\
\text { Кошти в ЦБ }\end{array}$ & \multirow{2}{*}{$0 \%$} \\
\hline $\begin{array}{l}\text { Інші зобов'язання } \text { (строком } \\
\text { більше } 1 \text { року) }\end{array}$ & & $\begin{array}{l}\text { Необтяжені } \\
\text { сертифікати }\end{array}$ & \\
\hline $\begin{array}{l}\text { Роздрібні депозити (строком } \\
\text { менше } 1 \text { року) }\end{array}$ & $90 \%$ & Цінні папери & $5-50 \%$ \\
\hline $\begin{array}{l}\text { Кошти нефінансових установ, } \\
\text { органів влади, центробанків } \\
\text { (строком менше } 1 \text { року) }\end{array}$ & $50 \%$ & $\begin{array}{l}\text { Кредити нефінансовим } \\
\text { установам, органам влади, } \\
\text { центробанкам } \quad \text { (строком } \\
\text { менше 1 року) }\end{array}$ & $50 \%$ \\
\hline \multirow[t]{2}{*}{$\begin{array}{lrr}\text { Інші } & \text { зобов’язанння } \\
\text { фінансові інструменти } & \end{array}$} & \multirow[t]{2}{*}{$0 \%$} & $\begin{array}{l}\text { Кредити фізичним особам } \\
\text { (строком більше } 1 \text { року) }\end{array}$ & $65-85 \%$ \\
\hline & & Інші активи & $100 \%$ \\
\hline
\end{tabular}

Для дотримання NSFR ASF повинно бути більше RSF. Якщо у банку всі кредити є довгостроковими, то застосовується підвищений коефіцієнт, який трансформується в підвищену потребу в стабільному фондуванні. Зокрема, для готівки i державних облігацій застосовуються коригуючі коефіцієнти від $0 \%$ до $5 \%$, для корпоративних боргових цінних паперів - 15\%, для депозитів, що знаходяться в інших фінансових установах для оперативних цілей, та кредитів банкам-кореспондентам - 50\%, для іпотечних кредитів $-65 \%$, для роздрібних кредитів та необоротних цінних паперів $-85 \%$, для інших активів $-100 \%$. Відповідно, до пасивів також застосовуються коефіцієнти залежно від виду і терміновості, а саме фінансування від Свропейського центрального банку та деривативи, що підлягають сплаті, зважується під 0\%, повне незабезпечене фінансування $-50 \%$, роздрібні депозити з залишковим терміном погашення менше одного року - 90-95\%, капітал 1-го рівня - 100\%. Коригуючі коефіцієнти відображають стабільність доступного фондування і дюрацію активу. 
Таким чином, на основі NSFR можна порівняти середньозважені показники терміновості активів та пасивів банків.

Дотримання нормативу NSFR створює стимули для банків до збільшення строковості пасивів, підвищення стабільності фондування та зменшення схильності до короткострокового фондування, тобто довгострокові кредити не мають фінансуватися за рахунок короткострокових депозитів. Це обумовлюється необхідністю запобігання надмірної залежності фондування неліквідних активів від короткострокових та волатильних джерел запозичень.

\section{Список використаних джерел}

1. Базельський комітет 3 банківського нагляду, Третя Базельська угода (Third Basel Accord). [Електронний ресурс]. - Режим доступу: https://www.bis.org/bcbs/basel3.htm

2. Реформи нормативів ліквідності банків. Національний банк України. [Електронний ресурс]. Режим доступу: https://bank.gov.ua/doccatalog/document?id=80321376

3. Базельський комітет з банківського нагляду, Базель III: коефіцієнт чистого стабільного фінансування [Електронний ресурс]. Режим доступу: https://www.bis.org/publ/bcbs271.pdf

Жердецька Л.В.

д.е.н., доиент

Одеський начіональний економічний університет,

м. Одеса, Україна

ORCID ID: http://orcid.org/0000-0001-5398-868X

\section{ЗАХИСНЕ ТА ПРЕВЕНТИВНЕ РЕГУЛЮВАННЯ СИСТЕМНОГО РИЗИКУ БАНКІВСЬКОГО СЕКТОРУ}

\footnotetext{
Узагальнення теоретичних засад регулювання банківського сектору економіки дозволяє визначити, що система регулювання системного ризику характеризується рівнями, суб'єктами, цілями,
} 
підходами та інструментами. Серед підходів необхідно виокремити захисне та пруденційне регулювання $[1,2,3,4]$.

Захисне регулювання має на меті абсорбцію негативних наслідків реалізації системного ризику (гарантування вкладів, державні гарантії, рефінансування, фінансова допомога проблемним банкам). Превентивне (пруденційне) регулювання спрямоване на попередження реалізації ризиків, а його мету можна визначити як забезпечення фінансової стійкості окремих банків та попередження реалізації системного ризику у банківському секторі економіки. Суб'єктами превентивного регулювання $є$ міжвідомчі органи та центральний банк. Інструментарій пруденційного регулювання формується у межах реалізації мікропруденційної та макропруденційної політик. Здійснювати захисне регулювання може центральний банк шляхом надання банкам рефінансування для підтримання ліквідності чи фінансової стійкості; фонд гарантування вкладів забезпечує функціонування системи страхування депозитів та реалізує на практиці захист інтересів вкладників у випадку банкрутства банків; уряд може здійснювати підтримку банків на засадах надання державних гарантій та фінансування.

Реалізація системного ризику призводить до значних економічних втрат (уповільнення економічного зростання та погіршення соціально-економічних показників), що підсилюється значними державними витратами на нівелювання наслідків системного ризику та підтримання фінансової стабільності. Зазначене вище вимагає використання таких підходів до регулювання системного ризику банківського сектора економіки, які б базувалися на попередженні надмірного накопичення системного ризику, що дозволить мінімізувати його негативні наслідки. У цьому зв'язку, 
більш дієвим у регулюванні системного ризику $є$ пруденційний підхід, використання інструментів якого дозволяє зменшити негативний вплив системного ризику на банківський сектор економіки.

\section{Список використаних джерел}

1. Кузнєцова Л.В. Теоретико-методологічні засади фінансової діяльності банку: моногр. - Одеса: Видавництво «Атлант», 2009. - 324 с.

2. Міщенко В., Науменкова С. Банківський нагляд: підручник. - К.: Центр наукових досліджень НБУ, 2011. - 498 с.

3. Шульга Н.П. Організаційне забезпечення ризик-менеджменту в банках України / Н.П. Шульга, М.В. Мельничук// Вісник КНТЕУ. 2012. - № 1(81). - C. 44-56.

4. Koumbarakis A. (2017) The Economic Theory of Bank Regulation and the Redesign of Switzerland's Lender of Last Resort Regime for the Twenty-First Century // thesis for the degree of Doctor of Economics and Social Sciences. - Fribourg, Switzerland 2017. - 307 p.

Жердецька Л. В.

д.е.н., доиент

ORCID ID: http://orcid.org/0000-0001-5398-868X

Черниш К. С.

студентка

Одеський національний економічний університет, м. Одеса, Украӥна

\section{ІДЕНТИФІКАЦІЯ ЕПІЗОДІВ СИСТЕМНОЇ БАНКІВСЬКОЇ КРИЗИ}

В дослідженні банківських криз найбільшого розповсюдження набув підхід, який дозволяє ідентифікувати системну банківську кризу. Банківська криза визначається як системна, якщо виконуються дві умови [1]: значні ознаки погіршення фінансової стійкості у банківській системі («банківські паніки», значні збитки, втрати в банківській системі та / або ліквідація банків); значне втручання регулюючих 
органів у відповідь на значні втрати в банківській системі. Необхідно зазначити, що державне втручання вважається значним при дотриманні принаймні 3-ох умов із 6-ти зазначених нижче: заморожування депозитів або відтермінування їхньої сплати («банківські канікули»); націоналізація системно значущих банків; витрати на реструктуризацію перевищують $3 \%$ ВВП; значна підтримка ліквідності (5\% депозитів нерезидентів); запроваджені значних гарантій; значна купівля активів (не менше 5 \% ВВП). Перший рік виконання обох критеріїв вважається роком визнання кризи системною. Кінець кризи визначається за рік до зростання реального ВВП та реального зростання кредиту, при чому позитивним це зростання має бути принаймні два роки поспіль.

Визначений вище підхід використовується фахівцями Світового банку, які наводять інформацію стосовно наявності системних банківських криз у країнах світу (рис. 1.)

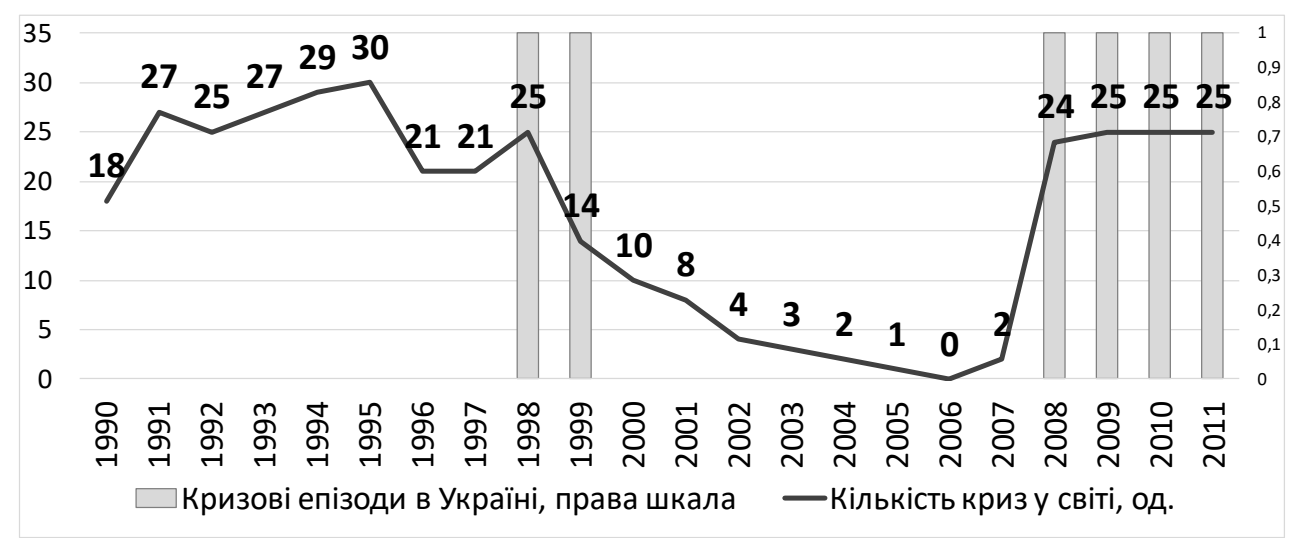

Рис. 1. Динаміка кількості системних банківських криз у світі та ідентифікація кризових епізодів в Україні в 1990-2011 рр. Джерело: складено за даними Світового Банку [2].

Таким чином, дані рис. 1 ілюструють зростання кількості банківських криз у періоди 1991-1996 рр., 1998 рік та 2008-2011 рр. 
Ідентифікація кризових епізодів повністю співпадає із іншими видами фінансових криз - валютними та інфляційними. Зазначене доводить взаємопов'язаність окремих видів фінансових криз та системний характер криз у визначені періоди. Підсумовуючи дані стосовно банківських криз в Україні, необхідно зазначити, що в банківській системі нашої держави протягом досліджуваного періоду переважали кризові роки -8 кризових епізодів та 4 граничні випадки порівняно із 7-ма відносно спокійними роками. Водночас такі часті випадки банківських криз не є специфікою української фінансової системи, а віддзеркалює світові тенденції.

\section{Список використаних джерел}

1. Laeven L. and Valencia F. (2013) Systemic Banking Crises Database: An Update // IMF Economic Review (2013) 61, 225-270. doi:10.1057/imfer.2013.12

2. Статистична інформація Світового банку [Електронний ресурс]. - Режим доступу: http://datatopics.worldbank.org/debt/ids/country/UKR\#

Кіресва К. О.

к.е.н., доиент

Київський національний торговельно-економічний університет,

м. Київ, Україна

ORCID ID: https://orcid.org/0000-0002-5686-9579

ВАЛЮТНЕ РЕГУЛЮВАННЯ В УКРАЇНІ: РЕАЛІЇ РОЗВИТКУ

Зарегульованість проведення валютних операцій в Україні була пов'язана 3 одночасною дією великої кількості законодавчих та нормативно-правових обмежуючих правил. Необхідність такого великого числа обмежень на проведення валютних операцій була пов'язана 3 прагненням зупинити, перешкодити, обмежити міграцію капіталу з України в інші країни. В результаті операції з валютними цінностями в Україні 
створювали непорозуміння, складнощі і спробу ухилитися від встановлених обмежень.

Прийнятий влітку 2018 року Закон України «Про валюту і валютні операції» скасував дію значного переліку обмежуючих проведення валютних операцій законів та нормативно-правових актів в сфері валютного регулювання, лібералізувавши валютні операції в Україні.

НБУ, в свою чергу, як основний суб'єкт валютного регулювання, скасував діючі до 2019 року нормативно-правові акти в сфері валютного регулювання. Натомість затвердив обмежений перелік нових правил регулювання валютних операцій із врахуванням віянь Закону України «Про валюту і валютні операції» і фінансової політики Держави.

Все це створює для суб'єктів господарювання і фізичних осіб ширші можливості розпоряджатися належними їм валютними цінностями на власний розсуд для реалізації власних цілей.

Відповідно до нових правил проведення валютних операцій в Україні дозволено:

- вільне відкриття рахунків юридичних осіб за кордоном,

- розрахунки в іноземній валюті за валютними державними облігаціями,

- валютні свопи банків з резидентами і нерезидентами,

- безпоставочні форварди та форварди для хеджування боргових операцій,

- ввезення-вивезення готівкової іноземної валюти та банківських металів юридичними особами,

- внесення платежів у іноземній валюті під час страхування життя,

- накопичення валюти на рахунках юридичних осіб для погашення зовнішніх запозичень,

- безлімітні інвестиції банків в цінні папери інвестиційного класу,

- інвестиції та кредитування резидентів з гривневих ЛОРО-рахунків банків-нерезидентів, 
- інвестиції в Україну також у валютах 2-ї групи класифікатора валют.

В той же час, скасовано перешкоди здійснення валютних операцій у вигляді:

- валютного нагляду для експортно-імпортних операцій до 150 тис. грн.,

- отримання індивідуальних ліцензій на валютні операції,

- санкції у вигляді припинення зовнішньоекономічної діяльності,

- ліміту на дострокове погашення зовнішніх зобов'язань,

- реєстрації зовнішніх запозичень,

- подвійного контролю операцій під час надходження митної декларації до іншого банку.

Разом з цим НБУ чітко вказує, що в разі погіршення макроекономічної стабільності фінансової системи і порушення рівноваги платіжного балансу України, він буде встановлювати обмеження на проведення валютних операцій, які існували до затвердження Закону України «Про валюту і валютні операції» враховуючи пріоритетність ринкових інструментів валютного регулювання над адміністративними.

На наш погляд, такі заходи 3 боку НБУ в сфері валютного регулювання свідчать про обережний і послідовний підхід до лібералізації проведення валютних операцій в Україні, який дозволить в разі неочікуваних, непередбачуваних наслідків негативного прояву економічного і соціального розвитку в країні, використати застосовувані раніше обмежувальні заходи щодо проведення валютних операцій для забезпечення фінансової стабільності в країні.

\section{Список використаних джерел}

1. Закон України «Про валюту і валютні операції» [Електронний pecypc]. - Режим доступу : https://zakon.rada.gov.ua/laws/show/2473-19

2. Сайт Національного банку України. - Режим доступу: https://bank.gov.ua/control/uk/publish/article?art_id=85295172\&cat_id=55838 
Київський національний торговельно-економічний університет, м. Київ, Україна ORCID ID: http://orcid.org/0000-0002-5876-1043

\section{ОЦІНЮВАННЯ БЕЗПЕРЕРВНОСТІ ДІЯЛЬНОСТІ БАНКУ}

Історично в Україні банки є об'єктом обов'язкового аудиту. Запровадження незалежного контролю при наявності в банках обов'язкового внутрішнього контролю ( служби внутрішнього аудиту) не спасають банки від ліквідації. Так на початку 2014 року в Україні діяло 180 банків, а станом на 1 січня 2019 року їх кількість скоротилась до 77 одиниць. Тому в процесі обов'язкового аудиту фінансової звітності перед аудитором постає наочне питання перевірки можливостей продовження банком діяльності, тобто дотримання ним принципу безперервності.

У МСА 570 «Безперервність діяльності» [1] викладені основні положення та аудиторські процедури, які повинен застосовувати аудитор при аудиторській перевірці фінансових звітів, підготовлених на основі припущення про безперервність діяльності. Припущення про безперервність діяльності полягає в тому, що банк продовжує ведення бізнесу в осяжному майбутньому, тобто має можливість виконувати свої зобов'язання у наступному звітному періоді. Відповідальність за оцінку здатності банку продовжити свою діяльність покладено на правління банку, але ця теза не знімає відповідальності із аудитора, який повинен отримати достатні та прийнятні аудиторські докази щодо можливостей безперервності діяльності банку. 
Оцінювання безперервності діяльності банку тісно пов'язано із прогнозування його банкрутства. Для прогнозуванні банкрутства можливо виділити: систему фінансових коефіцієнтів та групового аналізу; рейтингові системи оцінок банків; статистичні моделі; комплексні системи оцінки банківських ризиків. Загальновідомими $є$ методика Бівера, модель Пратта, використання карт Кохонена, багатофакторні моделі: 5-факторна модель Альтмана, 6-факторна модель Берзен Ейгі Ердогана, 8-факторна модель Юджина Кочака, агрегована модель Крухмаль Олени Валентинівни. Точність прогнозування у багатофакторних моделях різна, так у останніх трьох від 95\% до $98,5 \%$.

Аудитор самостійно вибирає методики прогнозування банкрутства банку, враховуючи їх переваги та недоліки, обмеження щодо використання у нестабільних умовах, i робить необхідні розрахунки. Для об'єктивного оцінювання перспектив безперервності діяльності банку необхідно врахувати вплив на неї визначених стандартом не фінансових події та умов. В разі виникнення у аудитора сумніву щодо можливості подальшого функціонування банку необхідно виконати додаткові аудиторські процедури, які допоможуть визначитись щодо цього питання i сформувати адекватний аудиторський звіт.

\section{Список використаних джерел}

1. Міжнародні стандарти контролю якості, аудиту, огляду, іншого надання впевненості та супутніх послуг (видання 2016-2017 років). Ч. 1 : пер. 3 англ. - К. : Міжнародна федерація бухгалтерів, 2016, Аудиторська палата України, 2018. - 1142 с. 
Нетребчук Л. О.

старший викладач

Київський національний торговельно-економічний університет,

м. Київ, Украӥна

ORCID ID: http://orcid.org/0000-0003-4942-5299

\section{НЕЯКІСНІ КРЕДИТИ БАНКІВ: ЗМІНА ПІДХОДУ ДО ВИЗНАЧЕННЯ}

Неякісні кредити завдають негативного впливу на фінансові показники та репутацію банку, тому стають об'єктом прискіпливого контролю як з боку самих банків, так і наглядових органів. При цьому важливе значення має питання критеріїв віднесення кредитів до «неякісних». Протягом функціонування банківської системи України підходи до визначення таких кредитів суттєво різнились - в нормативно-правових актах вони визначались різними термінами (проблемні, безнадійні, недіючі, непрацюючі, дефолтні) та змінювався ступінь врахування окремих категорій кредитів, що впливало на їх обсяг.

Відповідно до класифікації, що діяла до 2012 р., недіючими вважались «сумнівні» та «безнадійні» до повернення кредити, починаючи 3 IV кв. 2012 р. по IV кв. 2016 р. кредитні операції, класифіковані за IV та V категоріями якості, а з I кв. 2017 р. до них включаються кредити, класифіковані за найнижчим класом (за 10 класом - кредити, боржниками за якими є юридичні особи, за 5 класом - кредити інших боржників/контрагентів, в т.ч. фізичних осіб).

На сьогодні, в нормативній базі застосовується поняття «непрацюючі кредити» (nonperforming loans, NPL), які визначаються відповідно до Постанови НБУ № 351 від 30.06.2016, згідно якої непрацюючими визначаються кредити, за якими відбулася подія дефолту (тобто є факт прострочення платежу понад 90 днів (або 30 днів 
для банків-боржників), або якщо вчасне погашення боргу позичальником $є$ малоймовірним без стягнення забезпечення). Подія дефолту визнається у випадку наявності певних ознак, які поділяються на безумовні та «м’які» (коли банк на підставі судження не зміг довести відсутність дефолту). Варто також відзначити, що віднесення кредиту до категорії непрацюючих не залежить від наявність застави за таким кредитом.

Міжнародний стандарт фінансової звітності (IAS-39) вводить поняття знецінених активів (impaired asset), які виникають в наслідок однієї чи більше подій, що мають негативний вплив на очікувані грошові потоки та яким може бути надана достовірна оцінка. До переліку таких подій належать: можливість визнання банкрутства або іншої фінансової реорганізації з боку позичальника; надання поступок позичальнику, які за звичайних умов були би неможливими тощо.

Базельський комітет з питань банківського нагляду визначає, що актив/кредит $є$ непрацюючим при: визнанні його дефолтним; знеціненим (при переоцінці внаслідок погіршення кредитоспроможності); простроченні платежу понад 90 днів, чи існуванні низької ймовірності виконання своїх зобов’ язань боржником без реалізації застави.

Тобто, протягом останніх років підходи Національного банку України щодо оцінювання неякісних кредитів, які завдають негативного впливу на діяльність не тільки окремого банку, а й стабільність банківської системи, направлені на гармонізацію банківського законодавства з міжнародними підходами. 
Огородник В. В.

к.е.н., доцент

Інститут банківських технологій та бізнесу ДВНЗ «Університет банківської справи», м. Київ, Україна

\section{БАНКИ 3 ДЕРЖАВНОЮ УЧАСТЮ ТА ЇХ ВПЛИВ НА МОНЕТАРНУ ПОЛІТИКУ}

Вітчизняні банки $з$ державною участю перебувають на досить складному етапі свого функціонування (тільки починають відновлювати рівень прибутковості, знижують частку проблемної заборгованості в активах та відновлюють довіру населення), водночас, зберігаючи потенційні перспективи розвитку. Подальший розвиток банків 3 державною участю в Україні тісно взаємопов'язаний із реалізацією Стратегії реформування державного банківського сектору (2018 р. прийняття), Стратегії макропруденційної політики, а також 3 реалізацією Основних засадах грошово-кредитної політики.

Як заходи, що сприятимуть повноцінному високоефективному розвитку банків 3 державною участю в Україні, розцінюємо рекомендації Ради Національного банку України від 26 березня 2019 року Правлінню Національного банку України та Кабінету Міністрів України (рис. 1). Так, було розглянуто питання, що стосується діяльності банків з державною участю, політики Національного банку України по відношенню до них та впливу зазначених банків на ефективність трансмісійного механізму монетарної політики.

3 рис. 1 видно, що рекомендації щодо подальшого функціонування банків 3 державною участю стосуються корегування політики як Національного банку України щодо зазначених банків, так і Уряду країни (в особі Міністерства фінансів України). 


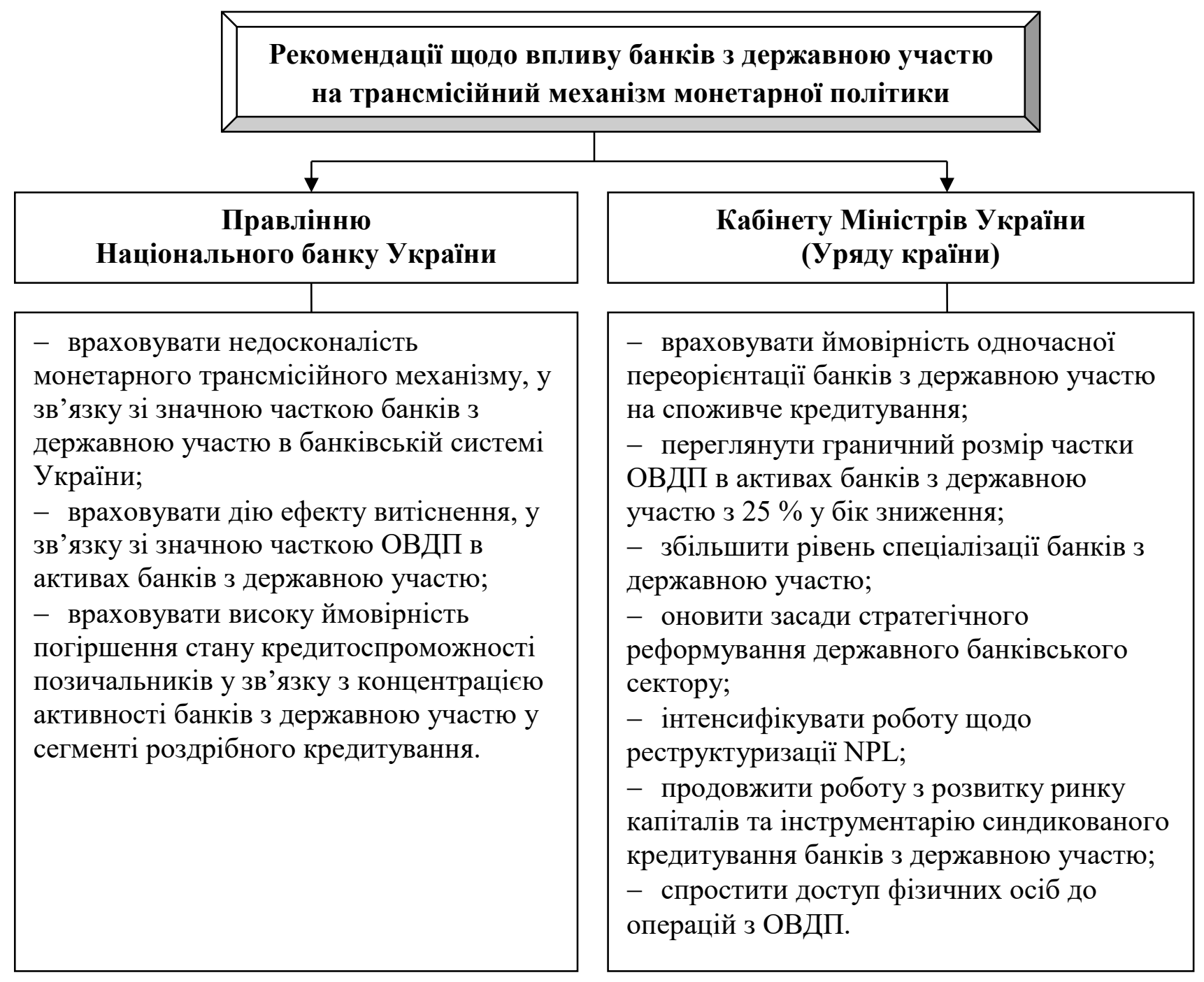

Рис. 1. Рекомендації щодо впливу банків 3 державною участю на трансмісійний механізм монетарної політики.

Джерело: складено автором на основі опрачювання [1].

Тож, серед основних рекомендацій Правлінню Національного банку України наголошено на недосконалості монетарного трансмісійного механізму через високу частку банків з державною участю в банківській системі країни [1]. Тобто, НБУ та КМУ мають прийматися виважені рішення 3 монетарної політики з урахуванням зазначених умов розвитку банків з державною участю.

\section{Список використаних джерел}

1. Рада НБУ. Рішення від 26.03.2019 р. № 11-рд «Про політику НБУ щодо державних банків та її вплив на ефективність монетарного 
трансмісійного механізму». [Електронний ресурс]. - Режим доступу: https://bank.gov.ua/doccatalog/document?id=91660816.

Плонка М.

д.е.н., професор

Краківський економічний університет,

м. Краків, Польща

Тринчук В. В.

к.е.н., доиент

Національний університет «Львівська політехніка»,

м. Львів, Україна

ORCID ID: https://orcid.org/0000-0001-7435-0159

Зелениця І. М.

старший викладач

Київський національний торговельно-економічний університет,

м. Київ, Україна

ORCID ID: https://orcid.org/0000-0002-8259-4281

\section{ДЕРЖАВНИЙ СТРАХОВИЙ НАГЛЯД КРАЇН ЄС: ДОСВІД ДЛЯ УКРАЇНИ}

Серед моделей державного регулювання варто виділити «інтегральну», в рамках якої функції регулювання фінансових ринків об'єднуються в єдиному органі, модель «twin peaks», що передбачає створення двох інститутів, повноваження між якими діляться на основі функціонального принципу: макростабільність і захист прав споживачів фінансових послуг та галузеву.

Перехід до мегарегулювання став основною сучасною тенденцією реформування фінансового регулювання і в історичному контексті $є$ закономірним результатом еволюції галузевої моделі регулювання в умовах глобалізації та конгломерації фінансового сектора після фінансової кризи 2008 року. 
У зв’язку з кризовими явищами в економіці України у 2014 році активно обговорювався проект удосконалення страхового нагляду i, зокрема, в першому читанні був прийнятий законопроект про передачу частини функцій від Нацкомфінпослуг до НБУ і НКЦБФР. Твердо переконані, що проста передача функцій регулювання до іншої інституції не вирішує проблеми ринку, про що неодноразово заявляли представники переважної більшості об’єднань фінансових установ України. НБУ інституційно до цього не готовий, є лише бажання бути монополістом, у той же час з подивом реагують іноземці на заяву членів Нацкомфінпослуг про підтримку спліту.

В Україні потрібно вдосконалити регулювання так, щоб воно було адекватним. Ухвалення закону про розділення функцій Національної комісії, що здійснює регулювання у сфері фінансових послуг (так званий «спліт» функцій Нацкомфінпослуг) було включено в меморандум співпраці між Україною і Міжнародним валютним фондом в 2017 році. У засобах масової інформації постійно з'являються різні заяви від представників Світового банку, Міжнародного валютного фонду, НБУ щодо консолідації функцій 3 державного регулювання ринків фінансових послуг й посиланням на «міжнародний», «європейський досвід». Хоча це не підтверджується на практиці (табл. 1), досвід доволі різний.

У ході проведеного дослідження прийшли до висновку, що законопроект про спліт втратив свою актуальність. На сьогодні НБУ фахово неспроможний забезпечити сучасний підхід до нагляду за учасниками страхового ринку України, до того ж галузева модель управління не з минулого століття, як заявляють деякі чиновники, вона дозволяє якісно контролювати діяльність страховиків в більшості країнах ЄС (див. табл. 1). 


\section{Органи страхового нагляду та чисельність страховиків у країнах ЄС та в Україні}

\begin{tabular}{|c|c|c|c|c|c|c|}
\hline \multirow[t]{2}{*}{ № } & \multirow[t]{2}{*}{ Країна } & \multirow[t]{2}{*}{$\begin{array}{l}\text { Орган, що виконує функції } \\
\text { страхового нагляду }\end{array}$} & \multirow[t]{2}{*}{$\begin{array}{c}\text { Дата } \\
\text { створення } \\
\text { нового } \\
\text { органу }\end{array}$} & $\begin{array}{c}\text { Кількість } \\
\text { страхових } \\
\text { компаній, } \\
\text { одиниць }\end{array}$ & $\begin{array}{l}\text { Чисельність } \\
\text { населення, } \\
\text { тис. осіб }\end{array}$ & $\begin{array}{r}\text { Кількість } \\
\text { компаній } \\
\text { на } 100 \text { тис. } \\
\text { населення }\end{array}$ \\
\hline & & & & \multicolumn{3}{|c|}{ станом на 1 січня 2018 р. } \\
\hline 1. & Німеччина & $\begin{array}{c}\text { Federal Financial Supervisory } \\
\text { Authority (BaFin) }\end{array}$ & 2002 & 528 & 82850 & 0,64 \\
\hline 2. & Бельгія & $\begin{array}{c}\text { National Bank of Belgium and } \\
\text { Financial Services and Markets } \\
\text { Authority (FSMA) }\end{array}$ & 2011 & 70 & 11413 & 0,61 \\
\hline 3. & Італія & $\begin{array}{c}\text { Institute for insurance supervision } \\
\text { integrated with that of Banca } \\
\text { d'Italia }\end{array}$ & 2013 & 103 & 60484 & 0,17 \\
\hline 4. & Люксембург & Commissariat aux Assurances & 1991 & 91 & 602 & 15,12 \\
\hline 5. & Нідерланди & $\begin{array}{l}\text { The Dutch Authority for the } \\
\text { Financial Markets }\end{array}$ & 2002 & 155 & 17181 & 0,90 \\
\hline 6. & Франція & $\begin{array}{c}\text { French Prudential Supervision and } \\
\text { Resolution Authority French } \\
\text { central bank }\end{array}$ & 2010 & 267 & 67222 & 0,40 \\
\hline 7. & Великобританія & $\begin{array}{c}\text { The Financial Conduct } \\
\text { Authority and The Prudential } \\
\text { Regulation Authority part of the } \\
\text { Bank of England }\end{array}$ & 2013 & 436 & 66238 & 0,66 \\
\hline 8. & Данія & $\begin{array}{c}\text { Danish } \\
\text { Financial Supervisory Authority }\end{array}$ & 1998 & 97 & 5781 & 1,68 \\
\hline 9. & Ірландія & $\begin{array}{l}\text { The insurance } \\
\text { Supervision Directorate of the } \\
\text { Central Bank of Ireland }\end{array}$ & 2010 & 253 & 4838 & 5,23 \\
\hline 10. & Греція & Bank of Greece & 2010 & 42 & 10739 & 0,39 \\
\hline 11. & Іспанія & $\begin{array}{l}\text { General Directorate for Insurance } \\
\text { and Pension Funds Ministry of } \\
\text { Economy, Industry and } \\
\text { Competitiveness }\end{array}$ & 2008 & 227 & 46659 & 0,49 \\
\hline 12. & Португалія & $\begin{array}{c}\text { Portuguese Insurance and Pension } \\
\text { Funds Supervisory Authority }\end{array}$ & 2015 & 41 & 10291 & 0,40 \\
\hline 13. & Австрія & $\begin{array}{l}\text { Financial Market Supervision in } \\
\text { Austria }\end{array}$ & 2002 & 80 & 8822 & 0,91 \\
\hline 14. & Фінляндія & $\begin{array}{l}\text { Finnish Financial Supervisory } \\
\text { Authority }\end{array}$ & 2009 & 50 & 5513 & 0,91 \\
\hline 15. & Швеція & Finansinspektionen & 1991 & 311 & 10120 & 3,07 \\
\hline
\end{tabular}




\begin{tabular}{|c|c|c|c|c|c|c|}
\hline 16. & Угорщина & Central Bank of Hungary & 2013 & 25 & 9778 & 0,26 \\
\hline 17. & Кіпр & $\begin{array}{c}\text { Directorates Insurance Companies } \\
\text { Control Service of Ministry of } \\
\text { Finance }\end{array}$ & 2016 & 33 & 864 & 3,82 \\
\hline 18. & Латвія & $\begin{array}{l}\text { Financial and Capital Market } \\
\text { Commission }\end{array}$ & 1997 & 6 & 1934 & 0,31 \\
\hline 19. & Литва & Bank of Lithuania & 2012 & 9 & 2809 & 0,32 \\
\hline 20. & Мальта & Malta Financial Services Authority & 2002 & 11 & 476 & 2,31 \\
\hline 21. & Польща & $\begin{array}{c}\text { Polish Financial Supervision } \\
\text { Authority }\end{array}$ & 2006 & 61 & 37977 & 0,16 \\
\hline 22. & Словаччина & Národná banka Slovenska & 2006 & 16 & 5443 & 0,29 \\
\hline 23. & Словенія & Insurance Supervision Agency & 2000 & 14 & 2069 & 0,68 \\
\hline 24. & Чехія & Czech National Bank & 2006 & 28 & 10610 & 0,26 \\
\hline 25 . & Естонія & $\begin{array}{c}\text { Finantsinspektsioon (Estonian } \\
\text { Financial Supervision and } \\
\text { Resolution Authority) }\end{array}$ & 2002 & 11 & 1319 & 0,83 \\
\hline 26. & Болгарія & Financial Supervision Commission & 2003 & 33 & 7050 & 0,47 \\
\hline 27. & Румунія & $\begin{array}{c}\text { Romanian Financial Supervisory } \\
\text { Authorit }\end{array}$ & 2013 & 31 & 19524 & 0,16 \\
\hline 28. & Хорватія & $\begin{array}{l}\text { Croatian Financial Services } \\
\text { Supervisory Agency }\end{array}$ & 2005 & 20 & 4106 & 0,49 \\
\hline 29 & Україна & $\begin{array}{l}\text { The National Commission for } \\
\text { State Regulation of Financial } \\
\text { Services Markets }\end{array}$ & 2011 & 294 & 42217 & 0,70 \\
\hline
\end{tabular}

* джерело: Інтернет-сайти регуляторів;

Population change - Demographic balance and crude rates at national level http://appsso.eurostat.ec.europa.eu/nui/show.do?dataset=demo_gind\&lang=en; Insurance companies by country https://www.insuranceeurope.eu/statistics/insurance-companies-country

Наслідки регулювання банківського ринку неоднозначні iз відходом з ринку значної кількості учасників та втратою довіри. А може у НБУ є бажання повторити досвід Росії? 32013 року повноваження з регулювання, контролю і нагляду в сфері фінансових ринків у Російській Федерації передано Центробанку. Число страховиків в Росії за 6,5 роки скоротилося більш ніж удвічі. Якщо у 2012 році працювало 463 компанії, то на кінець 2018 року їх залишилось 195. Щодо кількості гравців на страховому ринку 
зазначимо, що ми є прихильниками закону діалектики про перехід кількості у якість, а не створення штучних умов для ліквідації страхових компаній.

Маємо тверде переконання, що будь-якому ринку, і страховому в тому числі, потрібні стабільність, зрозумілі та чіткі «правила гри», передбачуваність державних рішень.

\section{Список використаних джерел}

1. Alyakina D., Kaigorodova G, Mustafina A. Development of a competitive environment as a factor of the qualitative growth of the Russian insurance market / Ad ALTA-Journal of Interdisciplinary. - 2018. - Toм №8. - Випуск №1. - С.101-105.

2. Alyeksyeyev I., Pozniakova O. Transformation of Ownership of the Banking System in Poland and Ukraine: Problems and Prospects /Financial Sciences. Nauki o Finansach, 2018. - Том №23. - Випуск №1. - C.33-48.

3. Arkhipov A., Trynchuk V. Establishment and development of insurance supervision in Russia and Ukraine: retrospective review /Insurance Markets and Companies. - 2017. - Issue №1 . - pp. 48-58.

4. Архипов А.П. Страховой надзор в России. Становление, использование зарубежного опыта, перспективы развития: Монография. - М.: РУСАЙНС, 2017. - 184 с.

5. Кайгородова Г. Реалии функционирования страхового рынка России. Современные исследования основных направлений технических и общественных наук: сборн. междунар. научнопрактической конф. Изд- во «Печать-сервис XXI век», 2017. - С.211214.

6. Клапків М., Клапків Ю. Витоки національного страхового ринку України: монографія. - Тернопіль: Карт-бланш, 2003. - 275 с.

7. Клапків Ю. Національний банк як потенційний регулятор ринку страхових послуг України //Управління інноваційною складовою економічної безпеки : монографія у 4-х томах / за ред. д.е.н., професора Прокопенко О.В. (гол. ред.), к.е.н., доцента Школи В.Ю., к.е.н. Щербаченко В.О. - Суми : ТОВ «Триторія», 2017.

8. Клапків Ю. Консолідація страхової справи та високих технологій у insurtech стартапах. Сучасні проблеми економіки та фінансів: Збірник матеріалів Міжнародної науково-практичної конференції. Київ, 30 жовтня 2018 р.-К.: КНЕУ, 2018.-117-119. 
9. Klapkiv L., Klapkiv J. Rynek ubezpieczeń na Ukrainie, główne problemy i czynniki determinujące jego rozwój / Rozprawy Ubezpieczeniowe. - 2017. - №2(24). - s.50-64.

10. Познякова О. Концентрація банківського капіталу в Україні / Фінансовий ринок: інституції та інструменти. - 2018. - №6. - 88-89.

11. Хоминич И., Тринчук В. Мегарегулятор финансовых институтов в России: влияние на страховой рынок// Современная экономика: концепция и модели инновационного развития: материалы V Междун. научно-практической конференции. 19 февраля 2013 г.: в 2 кн. - Кн. 2. - Москва: ФГБОУ ВПО «РЭУ им. Г.В. Плеханова», 2013. C.326-330.

12. Nadzór finansowy w Unii Europejskiej / Zeszyty Naukowe Uniwersytetu Przyrodniczo-Humanistycznego w Siedlcach. Seria: Administracja i Zarządzanie. - 2013. - № 97. - s. 169-176.

13. Sangowski T. Nadzór państwa nad działalnością ubezpieczeniową w Unii Europejskiej i w Polsce/Zeszyty Prawnicze . 2004. - №4/2.- s.71-92.

Смірнова Т. O. к.е.н., доиент Митровці М. студент Національний університет «Львівська політехніка» м. Львів, Україна

\section{ПІДВИЩЕННЯ РІВНЯ ФІНАНСОВОЇ НАДІЙНОСТІ СТРАХОВИХ КОМПАНІЙ}

На сьогодні в Україні зареєстровано близько 285 страхових компаній. За період незалежності зросла роль страхової діяльності, а отже й удосконалення методології оцінки результатів діяльності страхових компаній, серед яких найважливіше місце посідає фінансова надійність.

Вимоги до фінансової надійності страхових компаній суттєво збільшились. Тому пріоритетним стає не тільки облік грошових 
потоків компанії, а й комплексне дослідження іiі фінансовоекономічного стану, фінансової надійності та фінансової стійкості. Часто терміни «фінансова стійкість», «фінансова надійність» ототожнюють між собою, хоча ці поняття вживаються у різних значеннях. Так, фінансова стійкість трактується як синонім фінансового стану або як максимальна адаптація кількості і якості фінансових ресурсів страховика до середовища, в якому існує компанія. На нашу думку, таке ототожнення є некоректним, оскільки, фінансова надійність не може бути ототожнена 3 поняттям платоспроможності, вона стає незалежною від платоспроможності характеристикою поведінки системи в умовах змінних чинників. Ми вважаємо, фінансову стійкість варто аналізувати окремо, як складову фінансової надійності.

Проблема аналізу фінансової стійкості страхової компанії є багатофакторним завданням, яке вимагає комплексного підходу. Чинники впливу на фінансову стійкість страхової компанії можна поділити на три основні групи основні групи - це зовнішні, внутрішні та змішані чинники. До зовнішніх чинників належать кон'юнктура ринку та інфляція, внутрішніми є склад і структура витрат, склад i структура тарифної ставки, маркетингова політика страхової компанії, до змішаних - страхові резерви, статутний фонд, мобільність компанії. Для дослідження фінансової надійності також необхідно провести аналіз ліквідності та платоспроможності страхової компанії. 3 урахуванням ролі, цілей і стратегії на ринку фінансову надійність страхової компанії необхідно трактувати як стан фінансових ресурсів, за якого страховик: по-перше, здатний своєчасно виконувати всі взяті зобов'язання протягом всього терміну дії укладених договорів, подруге, мати задовільні показники діяльності, по-третє, сприятливо 
реагувати на зміну зовнішніх і внутрішніх чинників фінансового стану (тобто бути фінансово стійким). Таким чином, фінансова стійкість $є$ необхідною умовою фінансової надійності страхової компанії.

Для підвищення фінансової стійкості як складового елементу фінансової надійності доцільно, перш за все підвищити раціональність формування статутного фонду страховика.

3 огляду на це, для забезпечення фінансової надійності вітчизняних страховиків розмір їх мінімального статутного фонду слід розраховувати пропорційно до ризику, виду діяльності та терміну дії компанії на ринку.

Для формування статутного капіталу страхових компаній існує два основних підходи. Перший підхід передбачає поділ на три складових елементи - власний, залучений та позиковий. Другий підхід визначає, що капітал складається із власного та позикового. Значне коло науковців вважає, що капітал страхової компанії формується за рахунок власних, залучених та позикових коштів. Другий підхід максимально наближений до міжнародних та національних стандартів фінансової звітності, і власне зарубіжні автори поділяють весь капітал на капітал і зобов'язання [1].

Існують певні розбіжності щодо як самого розуміння мінімального капіталу так і вимог щодо розмірів цих капіталів. Слід зазначити, що вимоги Solvency II, запроваджуються в дію на теренах Європейського союзу з 1 січня 2016 року, та передбачають нагляд за розмірами капіталу у відповідності до визначених директивою.

Необхідно підкреслити, що склад та структура капіталу страхових компаній України значно спрощена 3 точки зору вимог Директиви Solvency II. Фактично такий підхід щодо формування капіталу страхових компаній з точки зору вітчизняного законодавства 
майже не враховує різні види ризиків, які супроводжують діяльність. А також створює значні можливості щодо формування платоспроможності страхових компаній лише у формах фінансової звітності без належного фінансового забезпечення виконання зобов'язань. Виходячи 3 такої схематичної побудови капіталу страхової компанії стає зрозумілим, що фактичний запас платоспроможності залежить від розміру статутного капіталу та інших елементів власного капіталу i нарощувати фактичний запас платоспроможності можливо за рахунок збільшення резервного капіталу, нерозподіленого прибутку та здійснюваної переоцінки активів і нарощення ринкової вартості акцій (за умови, що страхова компанія створена у вигляді акціонерного товариства). Звичайно можна говорити, що нарощення фактичного запасу платоспроможності можливе шляхом зменшення зобов'язань, але враховуючи, що одним iз найвагоміших елементів є страхові резерви, то це означає, що ми ототожнюємо зменшення зобов'язань із звуженням страхової діяльності, яка і лежить в основі діяльності, що забезпечує формування позитивного фінансового результату у вигляді чистого прибутку джерела поповнення гарантійного фонду [2].

Також фінансову надійність можна підвищити застосуванням для розрахунку тарифних ставок таких методів, які дають найоптимальніші величини тарифної ставки. Сукупність тарифних ставок називається тарифом. Система відображення тарифів називається тарифним керівництвом.

Для розрахунку тарифу може бути застосовано кілька методів: на основі теорії імовірностей, експертних оцінок, за аналогією до інших страхових компаній, 3 використанням математичної статистики i розрахунку дохідності. 
Кожен із зазначених вище методів розрахунку страхового тарифу має певні переваги та недоліки. На нашу думку, основною перевагою методів математичної статистики i теорії імовірностей $\epsilon$ їх математичне підгрунтя та найбільша точність результатів розрахунку. Методика експертних оцінок використовується, коли у фінансових системах страхування виникають проблеми, що виходять за межі формальних математичних постановок задач. Основний принцип 3'ясування колективної думки.

За тими ризиками, де неможливо застосувати зазначені методи, використовують метод аналогій з іншими страховими компаніями або іншими об'єктами, що страхуються. Перевагою такого методу є те, що страхові тарифи відповідають поточній кон'юнктурі ринку, оскільки страхова компанія орієнтується у їх встановленні на конкурентів; недоліком - те, що не враховуються певні індивідуальні особливості компанії.

Ми вважаємо, що найкраще для розрахунку тарифної ставки використовувати метод групових експертних оцінок, оскільки він враховує всі фактори, які впливають на тарифну ставку i при використанні цього методу можна використовувати інші методи визначення страхового тарифу, як додаткові джерела інформації для його оцінювання [3].

Крім цього, для підвищення платоспроможності, фінансової стійкості, а отже й фінансової надійності страховика необхідно здійснювати постійний моніторинг використання коштів компанії та визначити найоптимальніший розмір страхових резервів, які відображають обсяг страхових зобов'язань за укладеними договорами страхування. 
Фінансова надійність страховика забезпечується i таким інструментом, як перестрахування. Висока вартість об'єктів, які можуть бути прийняті на страхування, незбалансований страховий портфель, коливання результатів діяльності страховика можуть негативно вплинути на його фінансову надійність. Проте при перестрахуванні страховик, приймаючи на страхування крупний ризик, не тільки передає його частку перестраховику, а й продовжує нести відповідальність перед страхувальником у повному обсязі. 3 метою захисту виконання зобов'язань страховика перед страхувальниками Законом України «Про страхування» передбачається в обов'язковому порядку укладання угоди перестрахування у випадку, коли страхова сума за окремою угодою страхування перевищує 10 відсотків суми сплаченого статутного фонду і сформованих вільних резервів та страхових резервів. Страховики, які взяли на себе страхові зобов'язання в обсягах, що перевищують можливість їх виконання за рахунок власних активів, повинні застрахувати ризик виконання зазначених зобов'язань у перестраховиків [4].

Отже, збільшувати фінансову надійність страхової компанії можна застосуванням таких методів: оптимального розрахунку статутного капіталу, вибору методики групових експертних оцінок для розрахунку тарифної ставки і здійснення перестрахування. Формування власного капіталу потребує посилення вимог до нього i уподібнення цих вимог до європейського стандарту Solvency II, який $є$ більш складним і вимагає від страховика при формуванні капіталу враховувати більше ризиків і забезпечень. Застосування такого інструменту як перестрахування, оскільки перестрахування захищає 
страховика від ризику невиплати крупних страхових зобов'язань, сума яких перевищує 10 відсотків від статутного та резервного фондів.

\section{Список використаних джерел}

1. Аналіз фінансового потенціалу страхової компанії та механізму його формування // Економічна наука. - 2018. - №12. - С. $61-65$.

2. Структура капіталу страхових компаній: вітчизняні та європейські вимоги // Финансы, учёт, банки. -2016. -№21.-С. 225-233.

3. Методологія розрахунку страхових тарифів та платежів у майновому страхуванні [Електронний ресурс] - Режим доступу до pecypcy: https://works.doklad.ru/view/IBge6UhHcyY/all.html

4. Актуальні проблеми та перспективи розвитку страхування в Україні. // Економіка і суспільство. - 2017. - №10. - С. 589-597.

Степаник А. О. стариий викладач Київський національний торговельно-економічний університет, м. Київ, Україна ORCID ID: http://orcid.org/0000-0002-0054-8020

\section{MEXAHIЗM BAIL-IN - IHСТРУМЕНТ ФIНАНСОВОГО ОЗДОРОВЛЕННЯ БАНКІВ}

Невиконання багатьма банками України програм капіталізації свідчить про необхідність впровадження нових інструментів рекапіталізації, зокрема механізму bail-in, який полягає у примусовій конвертації незабезпечених вимог кредиторів у субординовані депозити або статутний капітал банку. Тобто передбачається, що клієнти банку (а саме великі вкладники й кредитори) за рахунок конвертації своїх депозитів у капітал та набуття прав акціонерів відновлюють платоспроможність цієї фінансової установи.

Рада 3 фінансової стабільності (FSB) разом 3 Базельським комітетом 3 банківського нагляду розробили «Стандарти 3 
реструктуризації та упорядкування ліквідації фінансових інститутів на випадок їх невідповідності (банкрутства)». Відповідно до цих норм національні уряди мають впроваджувати механізм внутрішнього викупу - bail-in.

Як правило, у країнах Євросоюзу механізм bail-in використовується у випадках, коли держава не може використати інструмент bail-out, який покладає фінансові витрати на порятунок банку або на все суспільство, або на кошти окремих регуляторів через надання регуляторних послаблень самому банку. Такий спосіб порятунку сприяє фінансовій безвідповідальності як вкладників («банк все одно врятують»), так і самих банкірів. Механізм bail-out виявився неефективним і постала потреба в розробці нових принципів та механізму.

Україна під час останніх фінансових криз зазнала великих витрат через використання механізму bail-out, який проявлявся через випуски ОВДП та виплати Фондом гарантування вкладів фізичних осіб. У зв'язку з цим вважаємо за доцільне внести зміни до законодавства України відповідно до прийнятої у Свропі Директиви 2014/59/СС, і тим самим закріпити механізм bail-in на національному рівні з урахуванням європейських стандартів. Зміни та доповнення, які пропонується внести до законодавства України, мають стосуватися таких аспектів як:

- черговість конвертації зобов'язань кредиторів у капітал банку. Зосередити увагу насамперед на пов'язаних особах і водночас регламентувати порядок конвертації коштів фізичних і юридичних осіб;

- $\quad$ розробка системи відповідальності за банкрутство банку згідно зі ст. 34 Директиви 2014/59/СС;

- $\quad$ розробка системи оцінювання зобов'язань банку перед їх 
конвертацією у капітал відповідно до ст. 36 Директиви 2014/59/СС;

- $\quad$ розробка системи оцінки бази bail-in відповідно до ст. 46 Директиви 2014/59/€C ;

- $\quad$ зняття заборони на використання поточних та депозитних коштів клієнтів при конвертації зобов'язань у капітал, встановивши при цьому граничне значення, вище якого кошти клієнта будуть підлягати конвертації.

Отже, необхідно внести зміни у законодавство України, які б регулювали впровадження механізму bail-in 3 метою відновлення платоспроможності банків в Україні, з використанням норм Директиви EC BRRD , та імплементувати bail-in при санації банків.

Шульга Н. П.

д.е.н., професор

Київський національний торговельно-економічний університет,

м. Київ, Україна

ORCID ID: http://orcid.org/0000-0002-2010-5884

\section{УПРАВЛІННЯ РИЗИКАМИ В БАНКАХ УКРАЇНИ: ЗМІНА СТЕРЕОТИПІВ}

Руйнівні наслідки світової фінансової кризи, втрати від якої в розрізі країн коливалися в межах від 1\% до 44\% валового внутрішнього продукту, викликали необхідність переходу до нової парадигми управління ризиками в фінансовій сфері. Особливо гостро ця проблема постала перед банками як носіями ризиків. 3 метою запобігання фінансовим кризам Базельським комітетом 3 питань банківського нагляду були розроблені рекомендації (Базель III), спрямовані на посилення вимог регуляторів до системи управління ризиками та ролі ризик-менеджменту в управлінні банками. У контексті цих 
рекомендацій Національний банк України прийняв постанову №64 «Про затвердження Положення про організацію системи управління ризиками в банках України та банківських групах» від 11.06.2018р., відповідно до якої передбачаються кардинальні зміни у системі управління ризиками вітчизняних банків, зокрема:

- формування корпоративної культури банку та проактивної культури управління ризиками, націленої на упередження настання кризових ситуацій в майбутньому;

- підвищення рівня відповідальності Ради та бенефіціарів банку, що сприятиме обмеженню проведення ним високоризикових операцій;

- створення трьохрівневої «лінії оборони» банку від настання ризиків, перша з яких - підрозділи фронт- та бек-офісів, друга - служба ризик-менеджменту, третя - внутрішнього аудиту, що створює підгрунтя для підтримки цілісності системи управління ризиками;

- забезпечення незалежності служби ризик-менеджменту та надання їй права «вето» на прийняття управлінських рішень, які можуть призвести до порушення фінансової стійкості та надійності банку;

чітке визначення функцій, повноважень та відповідальності Ради, Правління, профільних комітетів, служб ризик-менеджменту, комплаєнс, внутрішнього аудиту та інших учасників системи управління ризиками, а також налагодження тісної комунікації між ними;

- імплементація політики винагород в процес ризикменеджменту банку;

- обов'язковість розробки нових внутрішньобанківських документів, а саме - декларації схильності банку до ризиків, стратегії 
непрацюючих активів, політики запровадження нових продуктів i значних змін у діяльності банку, процедури ескалації порушень лімітів ризиків, методики виявлення суттєвих ризиків, політики запобігання конфліктам інтересів та інших;

- запровадження оновленої операційної моделі банку та стрес-тестування його суттєвих ризиків;

- окреслення контурів інформаційних систем та звітів;

- підвищення рівня прозорості результатів діяльності та ризиків банку із зазначенням припущень, інструментів та моделей вимірювання ризиків тощо.

Проведені нами дослідження дозволили виявити не тільки можливі позитивні зрушення в системі управління ризиками в банках України, але й ідентифікувати труднощі в реалізації рішень нової постанови НБУ. Зокрема, неоднаковий рівень розвитку ризикменеджменту в зарубіжних та вітчизняних банках призведе до неможливості більшістю з останніх дотримання календарного графіку виконання вимог постанови. Це пояснюється тим, що дочірні установи іноземних банків в Україні ще десять років поспіль розпочали впровадження вимог Базеля III, а відтак у них вже сформувалася система управління ризиками, яка наближена до нових вимог НБУ. До того ж, у малих приватних вітчизняних банках відсутні: кваліфіковані ризик-менеджери; відповідна статистична база для розрахунку ризикапетиту в цілому та по окремим видах суттєвих ризиків, а також економічного капіталу на основі VAR методології; спеціальне програмне забезпечення.

Отже, започаткування інноваційних підходів до ризикменеджменту в вітчизняному банківському секторі України сприятиме: з однієї сторони, підвищенню ефективності управління 
ризиками банків, що є запорукою підтримки їх фінансової рівноваги та стресостійкості, а з іншої сторони - зростанню їх витрат, пов'язаних із виконанням вимог Національного банку України, що призведе до тимчасового зниження банківської прибутковості.

Список використаних джерел:

1. Положення про організацію системи управління ризиками в банках України та банківських групах: Постанова Правління Національного банку України від 11.06.2018 №64 [Електронний pecypc].

Режим доступу:

https://bank.gov.ua/document/download?docId=71600453

\section{СЕКЦІЯ 3}

\section{ПІДПРИЄМНИЦЬКА ДІЛОВА АКТИВНІСТЬ В БІЗНЕС-ЦИКЛІ}

Головач Н. А. к.е.н, доиент

Київський національний торговельно-економічний університет, м. Київ, Україна ORCID ID: https://orcid.org/0000-0002-8012-6337

\section{ДІЛОВА АКТИВНІСТЬ ПІДПРИЄМСТВА В БІЗНЕС-ЦИКЛІ}

За сучасних умов суб'єкти господарювання повинні підвищувати ефективність діяльності, що сприятиме покращенню стану національного господарства в цілому.

Виникнення і розвиток поняття ділової активності діалектично зумовлене та практично виправдане, оскільки загалом відображає сутність змін в економіці, за яких гостро постає потреба зіставлення розмірів вкладених ресурсів 3 результатами їх використання, що 
пов'язане $з$ фінансовим станом суб'єктів господарювання. Ділова активність зазнала якісних змін у процесі розвитку світового господарства, ринкової економіки та підприємництва. Останнє здійснюється в умовах ділових ризиків, які викликали необхідність корегування окремих аспектів діяльності. Дослідження ділової активності $є$ досить важливим та актуальним, особливо на сучасному етапі розвитку економіки України. Від об’єктивності та точності оцінки ділової активності підприємства залежить якість важливих управлінських рішень, які дають змогу не пристосовуватися до змін на ринку, а активно реагувати на відповідну мінливу ситуацію [1, с. 145].

Ділову активність підприємства можна представити як систему якісних і кількісних критеріїв.

Якісні критерії - це масштаб ринків збуту (внутрішніх і зовнішніх), репутація підприємства, конкурентоспроможність. Наявність стабільних постачальників і споживачів і тому подібне. Такі неформалізовані критерії необхідно зіставити 3 критеріями інших підприємств, аналогічних за сферою застосування капіталу. Кількісні критерії ділової активності визначаються абсолютними і відносними показниками. Серед абсолютних показників слід зазначити об'єм реалізації виробничої продукції (робіт, послуг), прибуток, величину авансованого капіталу (активи підприємства). Доцільно враховувати порівняльну динаміку цих показників [2]. Оптимальне відношення:

$$
\mathrm{T}_{\Pi}>\mathrm{T}_{\mathrm{B}}>\mathrm{T}_{\mathrm{B \Pi}}>\mathrm{T}_{\mathrm{aK}}>\mathrm{T}_{\mathrm{cK}}>100 \%,
$$

де $\mathrm{T}_{п}-$ темп зміни прибутку, \%; $\mathrm{T}_{\text {в }}$ - темп зміни виручки від реалізації

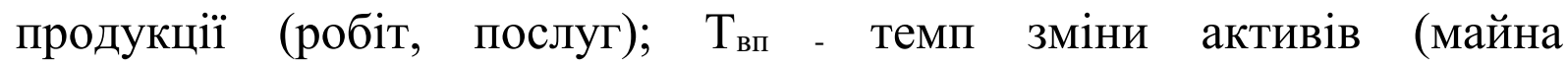

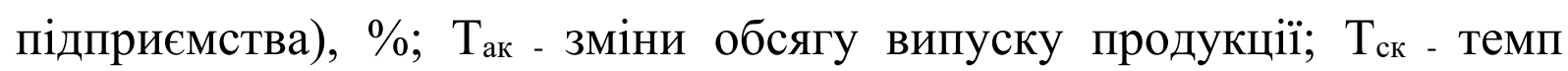
зростання власного капіталу. 
Приведене співвідношення має назву «Золоте правило» розвитку економіки підприємства: прибуток повинен зростати більш високими темпами, ніж обсяг випуску продукції, об'єм реалізації продукції і зростання майна підприємства Це означає: витрати виробництва і обігу повинні знижуватися, а ресурси підприємства використовуватися ефективніше. Проте на практиці навіть у стабільного підприємства в деяких випадках можливе відхилення від цього співвідношення. Причини можуть бути різними: великі інвестиції, освоєння нових технологій, реорганізація структури управління і виробництва (стратегічні зміни, організаційний розвиток), модернізація і реконструкція. Ці заходи, як правило, викликані впливом зовнішнього середовища (зовнішнє оточення) і вимагають значних фінансових вкладень, які окупляться і принесуть вигоду в майбутньому [2].

Відносні показники ділової активності характеризують рівень ефективності використання ресурсів (матеріальних, трудових i фінансових). Система показників ділової активності базується на даних бухгалтерської (фінансової) звітності підприємства. Ця обставина дозволяє за допомоги даних розрахунку показників контролювати зміни у фінансовому стані підприємства і його ділової активності [2].

Зазначимо, що ділова активність має тісний зв'язок $з$ іншими найважливішими характеристиками підприємства (інвестиційна привабливість, фінансова стійкість, кредитоспроможність). Так, висока ділова активність, що проявляється господарюючим суб'єктом, мотивує потенційних інвесторів до здійснення операцій з активами цього підприємства. Банки охоче надають кредити підприємствам 3 високими показниками ділової активності, оскільки вони здатні ефективніше їх використовувати і обслуговувати свої боргові 
зобов'язання. Отже, ділова активність $є$ однією 3 умов кредитоспроможності підприємства. Як правило, результатом підвищення ділової активності $€$ зміцнення фінансової стійкості суб'єкта господарювання [3, с.10].

\section{Список використаних джерел}

1. Гаркуша Н. М. Сутність ділової активності підприємства за ринкових умов та її види / Н. М. Гаркуша, Т. В. Польова // Кримський економічний вісник. - 2012. - №1 (01) грудень. - Ч. II. - С. 145-149.

2. Навчальні матеріали онлайн / Аналіз ділової активності в системах бізнесу // Електронний ресурс - Режим доступу: https://pidruchniki.com/82721/ekonomika/analiz_dilovoyi_aktivnosti_siste mah_biznesu

3. Ділова активність підприємства: сутність та методика аналізу : монографія / Н.Б. Кащена, О.О. Горошанська, Т.В. Польова [та ін.]. Х.: Видавництво Іванченка І.С., 2016. - 196 с.

Гуминська М. В. старший викладач

Київський національний торговельно-економічний університет м. Київ, Україна ORCID ID: https://orcid.org/0000-0001-5849-8452

\section{КОНТРОЛІНГ В ЗАБЕЗПЕЧЕННІ ПЛАТОСПРОМОЖНОСТІ СТРАХОВИХ ОРГАНІЗАЦІЙ}

Нестійкість економічної ситуації, яка склалася на сучасному етапі розвитку України, призводить до того, що успіх діяльності страхових організацій та забезпечення відповідного рівня їх платоспроможності значною мірою залежить від обраних методів здійснення управлінської діяльності, які дають можливість забезпечити ефективну роботу всіх підрозділів. В цих умовах керівництву страхових організацій у більшості випадків бракує інструментів та фахових знань, і управлінські рішення приймаються на 
основі інтуїції та життєвого досвіду, без застосування необхідного економічного фундаменту та комплексних, аналітичних висновків.

Одним 3 найпоширеніших, систематизованих й досконалих підходів є контролінг, що надає можливість ефективно управляти страховою організацією і забезпечувати ії довгострокове ефективне функціонування. Контролінг - поняття, яке носить системний характер, тому автори розглядають його з різних точок зору. Однак усі автори сходяться в тому, що контролінг не зводиться до простої системи контролю, а охоплює більш широку сферу діяльності страхової організації, тому контролінг можна визначити як комплексну систему, що включає:

- спостереження, вивчення та оцінку інформації про стан зовнішнього середовища i поведінки внутрішнього економічного механізму страхової організації;

- розробку цілей діяльності страхової організації i шляхів їх досягнення;

- перевірку, наскільки успішно страхова організація наближається до своєї мети.

Важливим моментом, що забезпечує ефективність функціонування контролінгу, є розробка механізму його впровадження у страхових організаціях.

У науковій літературі недостатньо уваги приділяється проблемі створення механізму формування системи контролінгу на підприємствах різних галузей з урахуванням особливостей їх розвитку у сучасних умовах.

Вважаємо, що механізм впровадження системи контролінгу у страховій організації має передбачати виконання наступних етапів: визначення цілей, стратегічних завдань та основних інструментів; 
організаційно-інформаційна підготовка впровадження у страховій організації контролінгу й звітності; впровадження процедур планування; впровадження процедур і механізмів контролю.

На першій стадії визначається мета впровадження контролінгу. Залежно від мети вибирається набір інструментів, які будуть упроваджуватися, та визначаються строки впровадження. На цьому етапі необхідно розробити поточні і стратегічні завдання як для страхової організації в цілому, так і по основних її підрозділах.

На другому етапі відбувається методична підготовка до впровадження контролінгу. 3 цією метою коригується структурна схема страхової організації, на якій вказуються центри витрат i відповідальності, вхідні й вихідні з підрозділів інформаційні потоки, а також бази даних, що існують у середині підрозділів.

Далі задаються основні вимоги до системи управлінської звітності - «як треба». На цьому етапі вирішуються такі завдання:

- своєчасне одержання керівництвом поточної інформації про діяльність страхової організації (у зручномуформаті);

- поліпшення взаємодії між підрозділами;

- скорочення часу прийняття управлінських рішень шляхом зменшення невизначеності;

- оптимізація витрачання фінансових, матеріальних і кадрових ресурсів страхової організації.

На третьому етапі при впровадженні процедур планування необхідно розробити формат планів і завдань для різних підрозділів із залученням усіх рівнів керівництва, визначити методики складання планів. Планування повинне охоплювати ключові показники діяльності страхової організації, бюджети доходів та витрат, прибуток, програми інвестицій і фінансування тощо. 
На останньому етапі вводяться в дію механізми контролю за відповідністю фактичних показників плановим, а також розробляється система раннього запобігання можливих відхилень.

Отже, для українських страхових організацій, особливо тих, що створені у формі акціонерних товариств та відносяться до розряду великих, вкрай необхідним стає впровадження контролінгу, одна 3 головних функцій якого полягає в забезпеченні координації різних систем - планування, обліку, контролю, аналізу та інформаційного забезпечення.

\author{
Danylkiv Kh.P. \\ PhD in Economics, Senior Lecturer \\ «Lviv Polytechnic» National University, \\ Lviv, Ukraine
}

\title{
FINANCIAL-CREDIT INSTRUMENTS INNOVATIVE DEVELOPMENT OF SMALL ENTERPRISE STRUCTURES IN UKRAINE
}

Among the regulatory mechanisms, an important role belongs to financial and credit instruments, in particular in the field of innovative development of small business. Small business is legitimately considered as one of the key economic system, since the need for it is conditioned by the need to ensure socio-economic stability in the state and productive efficiency.

In the conditions of dynamic development of modern society, the main direction of stimulation of economic growth of small business entities is innovative development, which involves the use of fundamentally new advanced technologies, the transition to the production of high-tech products and the development of mechanisms for implementing management 
decisions in innovation activities. The current state of the national economy requires intensive innovation, effective organization of the research and development process, innovations, strategic management in the innovation activity of each small enterprise. To strengthen their position in the market and effective innovation, small business entities are forced to seek new sources and forms of investment and form an effective system of measures for their financial and credit support.

A prerequisite for the innovative development of small business entities is the availability of effective financial and credit support, and it is therefore important at a macroeconomic level to develop a comprehensive and effective system of financial and credit support for the innovative development of small business in Ukraine and to find out the role of the state in its stimulation.

Note that the most common way of supporting the innovation activity of small business entities is bank lending. Commercial bank loans are an important financial tool for stimulating and securing innovation, since the need to repay a loan within a specified period makes the borrower speed up the innovation process.

Leasing is a fairly common method and powerful impetus for the activation of innovative entrepreneurial activity, as well as for the financing of the real sector of the economy. Activation of leasing services is a very significant tool for the innovative development of small business entrepreneurship, because it is a rather effective way of attracting additional funds and a wonderful alternative to bank lending, since the terms of leasing are transparent and due to the lack of hidden payments; provides a powerful impetus to privatization processes, updating technological park of existing business structures and creation of new industries, optimizes the use of 
existing machine equipment and, on favorable terms, allows obtaining stateof-the-art domestic and foreign equipment.

For a beginner business, the most valuable and most beneficial privilege is the ability to use already exhausted technologies and equipment that has proved itself, supply services, promotional materials, a well-known and popular trademark, receive continuously methodical, technological and informational support and the opportunity to study and receive consultations in business process. It is substantiated that franchising as the most effective business model creates the favorable and necessary economic preconditions for small business entities, enabling the use of all the capabilities of large corporations.

It is important to use forfeiting in the system of financial support of scientific and technical activities. It is proved that this form of financing of innovations can significantly revive the innovative development of small business. Forfeiting - a financial transaction that turns a commercial loan into a bank through the purchase of a debt to a creditor. In the face of a shortage of funds for investing in innovation, the investor writes bills and receives a deferred payment, as well as bank guarantees to secure payments. Consequently, the bank, which performs forfaiting operations, finances innovation activity, and the buyer has the opportunity to lend to the entire innovation project.

We note quite active participation in financial support of domestic small business of international financial organizations, in particular EBRD, NUF, IBRD, USAID, KfW.

A viable financing instrument is a promising instrument of financial support for innovative development of small business. Such funding is fundamentally different from any other, including the most widespread banking, and has a number of specific features: the provision of funds for a 
long period of time on the principles of irretrievability, free of charge, without any guarantees or security; active role of the investor in the management of the funded project.

\section{References}

1. Buzko I. R. Strategic management of investments and innovative activity of the enterprise. Monograph / I. R. Buzko, O. V. Vartanova, G. O. Golubenko. - Lugansk: View of the SNU them. V. Dahl, 2002. - $176 \mathrm{pp}$.

2. Everything about business. [Electronic resource]. - Mode of access: http://pro-biznes.com.ua/statt-pro-bznes/malij-biznes-zarubizhnijdosvid.html.

3. Zimon G., Ostrowska-Dankiewicz A., Dankiewicz R., Baranovska V., Zelenitsa I. (2019) Trade policy in the aspect of trade credit in group purchasing organizations. Financial and credit activity: problems of theory and practice. - Vol 1. - № 28. - S.149-157.

4. Strategies and technologies innovative development corporations: monohrafiia / za nauk. red. d-ra ekon. nauk, prof. O.M. Polinkevych. - Lutsk : Vezha-Druk, 2018. - 416 s.

Душак М. I. аспірант Сумський державний університет м. Суми, Україна

\section{УПРАВЛІННЯ КАПІТАЛОМ ЯК БАЗОВИЙ ЕЛЕМЕНТ ФІНАНСОВОЇ АРХІТЕКТУРИ ПІДПРИЄМСТВ}

В сучасних економічних умовах, які характеризуються суттєвою нестабільністю функціонування фінансового сектору важливого значення набуває налагодження взаємодії між підприємствами реального сектору та фінансовими установами в частині формування їх капіталу. Сформована структура капіталу підприємства є одним із основних елементів його фінансової архітектури. Фінансова архітектура підприємства тісно пов'язана із сформованою бізнес- 
моделлю підприємства і залежить від іï різновиду. Під фінансовою архітектурою підприємств розглядаються сформована динамічна модель підприємства, що основана на фінансових відносинах між основними стейкхолдерами (власниками та менеджерами) та проявляється у сформованій структурі капіталу та відповідних наслідках у вигляді фінансових ризиків. Таким чином, саме управління структурою капіталу підприємства визначає рівень фінансових ризиків, що формує підприємство.

На нашу думку управління структурою капіталу $є$ базовим елементом фінансового менеджменту, але тісно взаємопов'язаним із іншими його елементами. При цьому, на відміну від розповсюджених стандартних підходів щодо основних елементів фінансового менеджменту таких як управління активами, управління витратами, управління прибутком підприємств, на наш погляд стратегія фінансового менеджменту підприємства повинна бути зосереджена не на об'єктах, а на цільових параметрах, таких як ліквідність, платоспроможність, рентабельність, фінансовий ризик. В досягненні кожного із цих цільових параметрів є вплив сформованої структури капіталу підприємства.

Фактично сформована структура капіталу $\epsilon$ основою для досягнення головної мети фінансового менеджменту, а саме забезпечення зростання рентабельності власного капіталу, тобто задоволення інтересів власників. 3 одного боку власники та менеджери своїми рішеннями визначають структуру капіталу, а з іншого боку вони отримують і реальний фінансовий результат, як плату за правильно чи неправильно обгрунтоване та прийняте рішення. Це в сукупності може відображати ефективність фінансової архітектури підприємства. Взаємозв'язок структури капіталу підприємства та 
цільових параметрів фінансового менеджменту проявляється в наступному: управління ліквідністю - використання сформованого капіталу для фінансування відповідних активів підприємства та узгодження їх між собою з точки зору ліквідності активу та терміну виконання фінансового зобов'язання; управління платоспроможністю - здатність виконати всі фінансові зобов'язання (обслужити капітал) перед всіма стейкхолдерами підприємства за рахунок отриманих фінансових результатів; управління фінансовими ризиками через виконання зобов'язань перед стейкхолдерами по обслуговуванню сформованого капіталу. Таким чином структура капіталу є з одного боку результатом прийнятих рішень власниками та менеджерами, а 3 іншого відображає ефективність існуючої фінансової архітектури.

Жердецька Л.В. д.е.н., доиент ORCID ID: http://orcid.org/0000-0001-5398-868X Овчинникова О.O. студентка Одеський начіональний економічний університет, м. Одеса, Україна

\section{БАНКИ ТА БАНКІВСЬКИЙ БІЗНЕС : НАУКОВІ ПІДХОДИ ДО ВИЗНАЧЕННЯ}

В умовах динамічного розвитку та постійній трансформації діяльності банків, все важче стає визначити їх економічну сутність, оскільки постійно формуються нові аспекти банківської справи.

Банківський бізнес розглядається на макро- (діяльність банківських установ держави чи певного регіону) і на мікрорівні (діяльність певної окремої банківської установи). Банківський 
бізнес - це господарська діяльність банківської установи, яка провадиться, безпосередньо, на підставі ліцензії від Національного банку України, на базі ресурсів банку, у відповідності до обраної стратегії на власний ризик з метою отримання прибутку. У світовій практиці вирізняють наступні моделі банківського бізнесу: сегментування (банківська діяльність обмежена певним видом операцій або сектором), та універсальності (діяльність банку на грошовому ринку не обмежується). [1, с. 312-313].

Проаналізувавши погляди різних вчених, можна виділити декілька підходів до формування поняття «банк»: правовий, економічний, загально-поверхневий. Правовий підхід базується на тлумаченні банку відповідно до чинного законодавства та зумовлений необхідністю регулювання діяльності банків. Економічний підхід передбачає розгляд банківської установи як суб'єкта економічної діяльності. У даному підході наявні дві варіації. Макроекономічний підхід розглядає банки як фінансових посередників, які здійснюють перерозподіл тимчасово вільних коштів від зберігачів до позичальників, забезпечуючи фінансовими ресурсами відтворювальні процеси. Мікроекономічний підхід базується на тому, що банк виступає підприємством, яке виробляє та реалізує фінансові послуги. Щодо загально-поверхневого підходу, то банк розглядається як установа, створена для залучення й розміщення грошових коштів, їх використання шляхом виконання розрахунків, надання кредитів тощо [2, с. 108-110]. Узагальнюючи наукові підходи до трактувань дефініції «банк», можна виокремити крім вище перерахованих - системний підхід. Згідно цього підходу банк - це суб'єкт господарювання, який що задіяний у фінансово-кредитній системі країни, ризикова діяльність якого спрямована на задоволення потреб різних верств населення в 
сфері розрахунково-кредитних відносин [3]. Запропоновані підходи до трактування сутності дефініції «банк» та «банківській бізнес» дають можливість обгрунтувати тенденції їх розвитку та напрями регулювання.

\section{Список використаних джерел}

1. Олексіч Д. Банківський бізнес як предмет визначення вартості/Д.Олексіч//Проблеми і перспективи розвитку банківської системи України: зб. наук.праць/УАБС НБУ. - Суми, 2006. - Т.17. - С. 311 - 318.

2. Гуляєва Л.П. Сучасні підходи до визначення економічної сутності банку // Теорії мікромакроекономіки. Збірник наук. праць / За ред. Мальчина Ю.М., Ніколенка Ю.В. - 2008. - Вип.28. - С.106 - 115.

3. Мельничук Н.Ю. Теоретичні підходи розуміння сутності дефініції «банк» й визначення його ролі в економічній сфері. - Електронний pecypc. - Режим доступу: http://global-national.in.ua/archive/42015/182.pdf

Кансва Т. В.

к.е.н., доиент

ORCID ID: https://orcid.org/0000-0002-3302-9593

Шевченко С. $\mathrm{O}$.

к.е.н., доиент

ORCID ID: https://orcid.org/0000-0001-5684-4534

Київький національний торговельно-економічний університет, м. Київ, Україна

\section{ОБЛІК ЗАПАСІВ В УСТАНОВАХ ДЕРЖАВНОГО СЕКТОРУ}

Трансформація міжнародних вимог та правил дає можливість виділяти нові об‘єкти обліку: фінансові та нефінансові активи, до яких якраз і належать запаси, що суттєво впливають на порядок формування значної частки витрат суб‘єктів державного сектору та висвітлення облікових даних у фінансовій звітності.

Добре функціонуючий державний сектор, який забезпечує якісні державні послуги відповідно до потреб громадян, а також розумно керує наявними фінансовими ресурсами сприяє економічному та 
соціальному зростанню країни. Стан справ в установі державного сектору відображається в бухгалтерському обліку, який є частиною процесу управління державними фінансами. Від правильного ведення обліку господарських операцій залежить розвиток не лише окремо взятої установи, а й держави в цілому.

Як свідчить аналіз нормативно-правової бази, організацію та методику обліку запасів розкриває НП (С) БОДС 123 «Запаси». Як зазначено в стандарті 123, запасами установ державного сектору визначають оборотні матеріальні активи, що їй належать та забезпечують іï функціонування. Запаси визнаються активом, якщо вартість запасів можливо достовірно визначити, існує ймовірність отримання суб'єктом державного сектору майбутніх економічних вигід, пов'язаних з їх використанням [1].

Використання запасів може здійснюватися тільки на цілі та завдання, які $є$ передбаченими статутними документами або ж в процесі надання платних послуг, які заплановані в кошторисі установи.

Бухгалтерський облік в установах державного сектору базується на загальноприйнятих у міжнародній практиці принципах, виконує управлінську, контрольну й інформаційну функції та має певні особливості. Тож відображаючи всі операції, пов’язані з виконанням кошторису, бухгалтерський облік дозволяє систематично зіставляти їх 3 плановими показниками та виявляти відхилення фактичних витрат від планових, що дозволяє підвищити рівень бюджетно - кошторисного планування. Також ефективне ведення бухгалтерського обліку в установах державного сектору дозволить одержувати повну інформацію про державні активи і зобов'язання, відкрити можливості складання прогнозу впливу господарських операцій на фінансову діяльність [2, 277]. 
Таким чином, облік запасів посідає важливе місце у формуванні витрат установ державного сектору, оскільки безпомилково відображена інформація про облік запасів, їх класифікацію та оцінку, визнання, термін експлуатації, методи вибуття дає змогу надати обліково-аналітичне забезпечення керівництву державними фінансами.

Модернізація обліку в державному секторі, зокрема стосовно обліку запасів, призвичаює вітчизняну облікову діяльність до міжнародних стандартів, що дає змогу створювати більш результативне інформаційне забезпечення для управління державними фінансами.

\section{Список використаних джерел}

1. Національне положення (стандарт) бухгалтерського обліку в державному секторі 123 «Запаси» - Наказ Міністерства фінансів України 12.10.2010 № 1202 .

2. Облік у бюджетних установах: Навчальний посібник. - 2-ге видання/ за заг. ред. Лень В.С. - Київ: Каравелла, 2017. - 564 с.

Маслова Н. О.

к.е.н., доцент

Київський національний торговельно-економічний університет,

м. Київ, Україна ORCID ID: http://orcid.org/0000-0001-9875-3788

\section{МАРКЕТИНГОВА СТРАТЕГІЯ БАНКУ}

Основним вектором розвитку сучасної банківської системи України на найближчі роки має стати іiі надійність, конкурентоспроможність та орієнтованість на клієнта. Реформування банківської системи неодмінно пов'язано з реформуванням діяльності кожного банку країни, що спричинено підвищеними ризиками ринкового середовища та необхідністю вибору раціонального варіанта формування ефективних маркетингових стратегій. 
В умовах конкурентного ринкового середовища, коли сучасні клієнти мають доступ до великого розмаїття схожих за ціновими та іншими характеристиками банківських продуктів різних фінансовокредитних установ, саме ефективно сформована маркетингова стратегія дозволяє банківській установі бути «видимою» для нього та створювати основу для довгострокової стабільності, що в свою чергу $є$ запорукою довіри до банку.

Вважаємо, що банкам України необхідно здійснювати роботу за такими напрямками: 1) розширення та диверсифікація клієнтської бази; 2) орієнтація на максимальне задоволення потреб клієнтів за рахунок найбільш повного використання конкурентних переваг и можливостей банку; 3) підвищення ефективної взаємодії з клієнтами 3 метою забезпечення рентабельності банку в цілому [1, с. 134].

Визначення маркетингової стратегії в умовах реформування банківського сектору $€$ однією 3 найголовніших завдань банку, оскільки саме вона, разом 3 бренд-стратегією, $\epsilon$ ключовою для створення зовнішнього образу та формування прихильності клієнтів.

Маркетингова стратегія банку в умовах реформування банківського сектору має відповідати на наступні питання:

1) у чому полягає його конкурентна перевага;

2) яке бачення майбутнього банку у подальших планах його власників та керівництва;

3) яке місце займають клієнти в його діяльності;

4) на які сегменти цільового ринку вона розрахована;

5) які існують ресурси для іiї виконання.

3 огляду на важливість клієнтів у подальшому розвитку банківського бізнесу, вітчизняні банки також повинні активно впроваджувати у своїй діяльності інноваційні інструменти маркетингу. 
Треба зазначити, що цілі маркетингової стратегії сучасного банку повинні повністю інтегрувати зі стратегічними цілями установи, якими, в першу чергу, повинно стати зменшення чутливості до зовнішніх потрясінь із метою запобігання системній кризі, посилення надійності та фінансової стійкості банку, а також розвиток широкого спектру послуг банку та підвищення рівня привабливості банку для клієнтів на основі клієнтоцентричного підходу.

\section{Список використаних джерел}

1. Богоявленський О. В. Вибір стратегії банківського маркетингу в умовах кризових явищ // Вісник економіки транспорту i промисловості. - 2016. - № 56 - С. 133-139.

Назарова К. О. д.е.н., доиент

Київський національний торговельно-економічний університет

м. Київ, Україна

ORCID ID: https://orcid.org/0000-0002-0133-7364

\section{SOX-АУДИТ В ЗАБЕЗПЕЧЕННІ ФІНАНСОВОЇ СТАБІЛЬНОСТІ ДЕРЖАВИ}

Економіка з відкритим доступом, частиною якої прагне стати й національна економіка, все більше приділяє уваги новим важелям забезпечення стабільності фінансової системи. Вагоме місце в цьому процесі приділяється перманентно діючий системі внутрішнього контролю. Так, під внутрішнім контролем прийнято вважати процес, який забезпечує відповідність функціонування конкретного об'єкта прийнятим управлінським рішенням i спрямований на успішне досягнення поставленої мети.

Скандал з публічним нафтогазовим «Enron» на початку нульових був достатнім, щоб показати американської громадськості та iï 
представників у Конгресі, що необхідні нові стандарти відповідності для публічного обліку та аудиту. Так, для того, щоб скоротити масштаби корпоративного шахрайства, П. Сарбейнс і М. Окслі розробили Закон (Акт) Сарбейнса-Окслі, відомий в світі під назвою "SOX", який спрямований на захист інтересів інвесторів (акціонерів). Правовий документ охоплює, серед іншого, такий ключовий елемент, як система внутрішнього контролю, про яку йдеться у відомій, одній 3 найбільш цитованих, статті $404 \mathrm{SOX}$, відповідно до якого СЕО (керівники компаній) зобов'язані документально оцінювати систему внутрішнього контролю, відобразивши в звіті іï суттєві недоліки і превентивні заходи по їх усуненню. Зазначений законодавчий акт стосується низки концептуальних питань, що мають першочергове значення для публічних компаній, акції яких котируються на фондових ринках. При цьому неважливо, утворені зазначені компанії у США чи в інших країнах. 32005 р. чинність цього акту розповсюджується на будь-який суб'єкт господарювання, що прагне розмістити свої акції на американських фондових біржах. В Україні поки що таких публічних компаній небагато, але кількість охочих вийти на американський ринок постійно зростає. До таких, що підпадають під дію цього акту, висуваються вимоги, головні з яких:

1. Усі публічні акціонерні товариства повинні включати внутрішні звіти у свою щорічну звітність.

2. Керівники повинні включати в протоколи для внутрішнього аудиту свої звіти.

3. Компанії повинні ввести на підприємстві системи внутрішнього контролю; відповідним чином оцінювати іiі, визначати слабкі місця та шляхи перевірки їі ефективності. 
Останні два десятиріччя розвиток внутрішнього контролю та доведеними в судах проблемами зовнішнього, незалежного, аудиту. Тож, один із самих впливових у царині аудиту актів, SOX, акцентує особливу увагу на:

• запровадженні ради з контролю;

• збільшенні відповідальності компаній;

- додаткових вимогах до розкриття фінансової інформації;

- конфлікті інтересів аналітиків;

- дослідженнях та звітах;

- кримінальній відповідальності за шахрайство;

- посиленні покарань за злочини посадових осіб;

- корпоративному шахрайстві та відповідальності тощо.

Плісак Т. O. к.е.н., доиент

Київський національний торговельно-економічний університет, м. Київ, Україна ORCID ID: http://orcid.org/0000-0002-8905-2805 ВПЛИВ МСФЗ 9 «ФІНАНСОВІ ІНСТРУМЕНТИ» НА ФІНАНСОВУ ЗВІТНІСТЬ БАНКУ

2018 рік для банків України став роком переходу на МСФЗ 9 «Фінансові інструменти», який встановив нові підходи до оцінки знецінення (зменшення корисності) фінансових активів на основі концепції очікуваних кредитних збитків. Модель понесених збитків за МСБО 39 «Фінансові інструменти» змінилася на модель прогнозованих очікуваних кредитних збитків.

Імплементований у практику українських банків МСФ3 9 має важливу складову - класифікацію активів відповідно до обраної банком 
бізнес-моделі управління фінансовими активами, яка грунтується на професійних судженнях відповідного управлінського персоналу банку.

Враховуючи, що по банківській системі України в цілому та досліджуваних нами банках (АТ КБ Приватбанк, АТ «Райффайзен Банк Аваль», АТ «Креді Агріколь Банк») у фінансових активах переважають кредитні активи нами було проведене дослідження впливу окремих положень стандарту на характер професійних суджень стосовно обгрунтування бізнес-моделі управління кредитними активами, застосування вартісної оцінки кредитів, оцінки резервів під очікувані кредитні збитки. Нами встановлено, що у всіх досліджуваних банках кредити класифікуються як фінансові активи, що обліковуються за амортизованою собівартістю і відповідають критерію за МСФЗ 9 «виключно виплата основної суми боргу та процентів на непогашену суму основного боргу».

Практика управління фінансовими активами в банках доповнилася новими елементами, а саме: проведення постійного аналізу обгрунтованості управлінських рішень щодо класифікації та подальшої оцінки фінансових активів на основі тестування бізнесмоделі згідно якої управляються кредитні активи та передбачених умовами договорів грошових потоків. Зокрема, АТ КБ «Приватбанк» для визначення бізнес-моделі управління фінансовими активами враховує бізнес-стратегію, цілі, прогнозні показники ліквідності, ефективності управління портфелями та притаманні їм ризики.

Відповідно до МСФЗ 9 у 2018 р. банки перейшли на створення резервів під очікувані кредитні збитки стосовно всіх кредитів, зобов'язань 3 кредитування та договорів фінансової гарантії. Такі резерви засновані на величині очікуваного кредитного збитку, пов'язаного 3 ймовірністю дефолту позичальника протягом 12 
наступних місяців, якщо не відбулося значного збільшення кредитного ризику з моменту первісного визнання кредиту. Фактори значного збільшення кредитного ризику визначені МСФЗ 9 як обов'язкові та мінімальні.

У річній фінансовій звітності за 2018 рік банки розкрили основні засади професійних суджень, які є суттєвими та необхідними при застосуванні вимог бухгалтерського обліку для оцінки очікуваних кредитних збитків. Зокрема, професіонали АТ Райффайзен Банк Аваль використовують кількісні, якісні та допоміжні критерії для визначення значного збільшення кредитного ризику, значення яких різне для роздрібного та корпоративного (нероздрібного ) бізнесу. До кількісних критеріїв банк відносить прострочення оплати протягом 30 днів або проведення реструктуризації внаслідок фінансових труднощів щодо певної заборгованості. Для нероздрібного бізнесу збільшення кредитного ризику є значним у разі відносного збільшення настання дефолту у 2,5 рази та більше; за роздрібним бізнесом порівнюються ймовірності настання дефолту акумульовані за період, що залишився до закінчення терміну дії кредитного договору. Для кожного окремого портфеля банк встановлює поріг, враховуючи характеристики відповідної рейтингової моделі. Порогові значення для переведення кредиту до 2 стадії зменшення корисності банк встановлює 3 урахуванням поточної ринкової практики, зміна якої може привести до використання нижчих порогових значень для певних ринків.

АТ «Креді Агріколь Банк » розраховує кредитні збитки для всіх активів на портфельній основі. У виняткових випадках як виключення, враховуючи професійні судження, може застосовуватись індивідуальна основа, проте рішення стосовно неї приймається Колегіальним органом банку. Для оцінки очікуваних кредитних 
збитків на портфельній основі названий банк використовує такі параметри як ймовірність невиконання зобов'язань контрагентом(РД), збиток у випадку дефолту (LGD), коефіцієнт кредитної конверсії $(\mathrm{CCF})$, кумулятивний коефіцієнт дострокового погашення (PRAC).

В цілому всі досліджувані банки у 2018 році сформували резерви під очікувані кредитні збитки, застосувавши 3-ступеневу модель зменшення корисності, яка базується на змінах в кредитній якості відповідних інструментів 3 моменту первісного визнання кредиту. Фінансовий інструмент, який не $є$ кредитно-знеціненим при первісному визнанні був класифікований у 1 стадію зменшення корисності, а його кредитний ризик $є$ предметом постійного подальшого моніторингу. Якщо відбувалося суттєве збільшення кредитного збитку, фінансовий інструмент був переведений до 2 стадії зменшення корисності, хоча не вважався кредитно-знеціненим. Кредитно-знецінені фінансові інструменти віднесені банками до 3 стадії зменшення корисності.

У фінансовій звітності за 2018 рік досліджувані банки розкрили інформацію про структуру кредитної якості кредитів та обсяги сформованих резервів після зміни моделі понесених збитків за МСБО 39 на модель прогнозованих очікуваних кредитних збитків за МСФЗ 9. Оцінюючи ефект зміни підходів до визначення кредитного ризику по досліджуваних іноземних банках спостерігається тенденція до зниження обсягу сформованих резервів у 2018 році порівняно 3 попереднім роком при одночасному збільшенню обсягу кредитного портфеля клієнтів банку. Розподіл резервів під очікувані кредитні збитки за стадіями зменшення корисності характеризується наступним: частка резервів, які сформовані по кредитах, віднесених до 3 стадії зменшення корисності коливається в межах 80\%, тоді як частка 
таких кредитів знаходиться в межах 6-9\%. У Приватбанку 99\% обсягу оціночних резервів сформовані під 83\% кредитів, які віднесені до 3 стадії зменшення корисності. В цілому, як досліджувані банки, так і весь банківський сектор за оцінкою НБУ у 2018 році отримав чистий прибуток загальним обсягом: 21,7 млрд. грн., покриття NPL резервами, які сформовані під очікувані кредитні збитки становить 95,5\%, якість кредитного портфеля поліпшилася i найвищими темпами кредитування розвивалося у іноземних та приватних банках.

\section{Список використаних джерел}

1. МСФ3 9 «Фінансові інструменти» [Електронний ресурс]. Режим доступу: https://zakon.rada.gov.ua/laws/show/929_016.

2. Фінансовий звіт АТ Райффайзен Банк Аваль за 2018 рік [Електронний pecypc]. - Режим доступу: https://ex.aval.ua/about/bank_reports/

3. Фінансовий звіт АТ «Креді Агріколь Банк» за 2018 рік [Електронний ресурс]. Режим доступу: https://credit-agricole.ua/obanke/dokumenti-ta-zviti.

4. Фінансовий звіт АТ КБ Приватбанк за 2018 рік [Електронний pecypc]. - Режим доступу: https://privatbank.ua/about/finansovajaotchetnost.

Роздобудько В. В. к.е.н., доиент

Київський національний торговельно-економічний університет,

м. Київ, Україна ORCID ID: https://orcid.org/0000-0003-1981-0831

\section{АУДИТ ФІНАНСОВОÏ ЗВІТНОСТІ ФІНАНСОВИХ УСТАНОВ}

Ринок фінансових послуг в Україні динамічно розвивається, що пов'язано з елементами кризових явищ на ринку банківських послуг. Виникає суспільна потреба, щодо підвищення ступеню суспільної довіри на ринку фінансових послуг. Аудит фінансової звітності 
фінансових установ покликаний підвищити рівень впевненості щодо діяльності цих установ.

Відображення всіх елементів звіту незалежного аудитору (аудиторського висновку) $є$ одним 3 основоположних аспектів здійснення аудиторської перевірки у відповідності до Міжнародних стандартів аудиту (МСА). Починаючи 32017 р. Звіт незалежного аудитора (Висновок аудитора) розширено на секцію «Ключові питання аудиту».

Задача ключових питань аудиту:

1) вказати яким чином оцінка суттєвості помилки вплинуло на процес аудиту;

2) звернути увагу користувачів на питання, які найбільше потребували уваги аудитів;

3) визначити як ці питання розкриті у фінансовій звітності та річному звіті.

Тобто, основне завдання ключових питань аудиту - забезпечення більшої прозорості для користувачів фінансової звітності.

Ключові питання аудиту повинні звернути увагу користувачів фінансової звітності на питання, які найбільше потребували уваги аудитів щодо того як ці питання розкриті у фінансовій звітності та річному звіті

Завдання елемента «Ключові питання аудиту» - це забезпечення більшої прозорості для користувачів фінансової звітності.

Визначення кількості ключових питань з аудиту залежить від судження аудиторів щодо важливості питань, які потребували значної їхньої уваги.

Звіт аудиторів є більш прозорим щодо важливих аспектів аудиту, краще описує, що являє собою аудит та що аудитори роблять. 
Параграф Ключові питання аудиту у звіті незалежного аудитора є стислим викладом питань 3 посиланнями на пов'язану інформацію, що розкривається у річному звіті. Параграф Ключові питання аудиту значно спрощує обробку фінансової звітності та пошук по документу, даючи користувачам фінансової звітності розуміння важливості проведеної аудиторами роботи.

\section{Список використаних джерел}

1. Міжнародні стандарти контролю якості, аудиту, огляду, іншого надання впевненості та супутніх послуг (видання 2016-2017 р.) [Електронний ресурс]. - URL: https://www.apu.net.ua/component/content/article/2-uncategorised/ 1151miznarodni-standarti-kontrolu-yakosti-2016-2017 - Назва з екрану.

Романишин В. O.

к. е. н., дочент, ДВНЗ «Київський національний економічний університет імені Вадима Гетьмана», м. Київ, Україна

ORCID ID: https://orcid.org/0000-0003-4864-5433

ТОРГОВЕЛЬНЕ ФІНАНСУВАННЯ У ЗАБЕЗПЕЧЕННІ СТРУКТУРНОЇ ТРАНСФОРМАЦІЇ НАЦІОНАЛЬНОЇ ЕКОНОМІКИ

Однією 3 головних рис сучасної світової економіки $\epsilon$ глобалізація, яка сприяє швидкому розвитку міжнародної торгівлі, про що свідчать вищі темпи іiі зростання порівняно з темпами зростання світового виробництва. У зв'язку з цим розроблення і застосування нових форм та інструментів кредитування зовнішньо-економічних контрактів національних підприємств $є$ актуальним. Одним 3 інструментів, що широко застосовується у міжнародній практиці $є$ торговельне фінансування. 
Торговельне фінансування - це фінансування проектів, пов'язаних з експортом чи імпортом товарів і послуг національними банками за рахунок кредитних ресурсів, залучених на міжнародних фінансових ринках, а також забезпечення виконання зобов'язань клієнта у рамках зовнішньо-економічних контрактів. Для забезпечення своєчасних розрахунків учасники зовнішньо-торговельних операцій використовують різні інструменти торговельного фінансування: відкритий рахунок, авансовий платіж, інкасо, акредитивні операції, банківські гарантії, страхове/гарантійне покриття ЕКА, міжбанківські кредити, цільові торгові кредити під час експорту та імпорту, факторинг, форфейтинг, лізинг та ін. [1; с.31].

За наявності значних структурних диспропорцій у національній економіці і структурі експорту зростає роль держави у забезпеченні сприятливих умов для просування високотехнологічної продукції на зовнішні ринки. Однак на сучасному етапі в Україні, на відміну від більшості країн світу, лише створюється інституційна система фінансової підтримки національного експорту з боку держави, що суттєво обмежує можливості стимулювання розвитку високотехнологічних експортно-орієнтованих галузей економіки. Це відображається на конкурентних позиціях національних товаровиробників на міжнародних ринках i сприяє консервації неефективної структури зовнішньої торгівлі та економіки.

Вирішенню зазначених проблем, на наш погляд, повинно сприяти застосування інструментів торговельного фінансування, що передбачають гарантійне забезпечення кредитних ризиків від експортних кредитних агентств. Експортні кредитні агентства, або ЕКА - це уповноважені органи, які реалізують державну політику підтримки експорту зі своїх країн шляхом здійснення страхування 
експортних політичних і комерційних ризиків та надання гарантій 3 метою забезпечення конкурентоспроможних умов просування продукції/послуг своїх фірм на міжнародні ринки та стимулюють і забезпечують гарантії інвестицій за кордон [2].

У лютому 2018 р. в Україні на виконання вимог Закону України «Про забезпечення масштабної експансії експорту товарів (робіт, послуг) українського походження шляхом страхування, гарантування та здешевлення кредитування експорту» створено ЕКА. Після повноцінного запуску роботи агентство здійснюватиме страхування, перестрахування і надання гарантій за договорами, які забезпечують розвиток експорту. Воно також братиме участь у виконанні програм часткової компенсації відсоткової ставки за експортним кредитом і надаватиме консультації експортерам.

Зважаючи, що в Україні здійснюються лише перші кроки на шляху створення ЕКА ряд питань функціонування агентства потребують уточнення i зміни. Зокрема, для будь-якого ЕКА принциповим $\epsilon$ питання, які статті експорту мали б отримати підтримку. Закон про ЕКА містить визначення понять «роботи, послуги українського походження», «товари українського походження» та «український експортер». Однак термін «українського походження» не $є$ достатньо точним і вичерпним. У світовій практиці концепції ЕКА відрізняють поняття «національний вміст» та «національний інтерес». Тому цей аспект потребує уточнення.

Також не всі товари, роботи та послуги, які виробляються в Україні або походять з України, мають право на підтримку ЕКА в рамках Закону про ЕКА. Так, сектори промисловості, які мають право на підтримку ЕКА, становили лише 16,5\% від загального експорту товарів з України у 2017 р. Зазвичай, експортно-кредитні агентства не 
встановлюють різниці між різними товарами, роботами та послугами, які потребують допомоги, оскільки потреба в підтримці може різко змінюватися, а тому жодна галузь промисловості не має бути формальною виключеною. Всі галузі української експортної промисловості повинні мати однаковий доступ до підтримки ЕКА.

Список використаних джерел

1. Банківське кредитування корпоративного сектору економіки в умовах циклічності : монографія / Л.В. Кузнєцова та ін. ; за ред. Л.В. Кузнєцової. Харків : Диса Плюс, 2018. 280 с.

2. Бойко $€$. Експортне кредитне агентство, як складова державного управління в підвищенні експорту / С. Бойко [Електронний pecypc]. - Режим доступу : http://www.nbuv.gov.ua/ejournals/NacGosp/2010/Boyko_EO.pdf

Рязанцева В. В. к.ф.-м.н., доцент Київький національний торговельно-економічний університет, м Київ, Украӥна ORCID ID: https://orcid.org/0000-0001-6379-1047

\section{ДОСЛІДЖЕННЯ ЦИКЛІЧНИХ ПРОЦЕСІВ НА ОСНОВІ ДИСТРИБУТИВНО-ЛАГОВИХ ТА АВТОРЕГРЕСИВНИХ МОДЕЛЕЙ}

Для багатьох економічних процесів типовим $є$ те, що ефект від впливу деякого фактору на показник, який характеризує процес, виявляється не відразу, а поступово, через деякий час (часовий лаг), або протягом деякого часу (лагу). Зазвичай це пов'язано з циклічністю та інертністю економічних процесів. Моделі, в яких досліджуваний показник визначається не лише поточними, а й попередніми значеннями незалежних змінних, розробляються на основі дистрибутивно-лагових рівнянь. 
Якщо в економетричній моделі зміна досліджуваного показника визначається значеннями незалежних змінних за декілька попередніх періодів, то такі моделі мають кінцевий лаг (скінчені моделі). Якщо ж вплив незалежної змінної не обмежується певним періодом, то розглядають нескінченні лагові моделі. Звичайно, нескінчена лагова модель є більш загальною, але практичне застосування такої моделі досить проблематичне через велику кількість факторів, складність внутрішньої структури та обмеженість часових рядів - інформаційної бази моделей.

Дистрибутивно-лагові моделі, або моделі розподіленого лагу, задовільно описують економічні процеси лише в стабільних (незмінних) умовах, а для врахування поточних умов функціонування, в модель вводять також незалежні змінні досліджуваного періоду. Якщо економетрична модель містить не тільки лагові змінні, але й ті змінні, що безпосередньо впливають на досліджуваний показник (поточні умови функціонування), то така модель називається узагальненою моделлю розподіленого лагу.

Якщо при моделюванні взаємозв'язків на основі багатомірних часових рядів необхідно описати залежність однієї змінної від інших і врахувати автокореляцію залежної змінної, то економетрична модель буде мати лагову (затриману) пояснюючу змінну (авторегресивна або динамічна модель). В таких моделях кореляція між регресорами i залишками $є$ серйозною перешкодою для застосування класичного методу найменших квадратів - оцінки можуть бути асимптотично зміщеними i неспроможними. Один із шляхів подолання цих труднощів - заміна регресорів, введення нових незалежних інструментальних змінних. 
Для отримання спроможних оцінок вони повинні мати дві властивості: нові змінні (регресори) повинні бути сильно корельовані 3 ісходними незалежними змінними (регресорами); нові змінні (регресори) не повинні бути корельовані 3 помилками. Основними способами визначення інструментальних змінних $\epsilon$ оператор оцінювання Вальда (застосовується для моделі з двома змінними), оператор оцінювання Бартлета, оператор оцінювання Дарбіна. Число інструментальнихзмінних повинно бути не менше числа вихідних незалежних змінних.

Застосування інструментальних змінних, навіть при наявності помилок в вимірюваннях залежної змінної, гарантує отримання незміщеною і спроможною оцінки параметрів.

Степанова I.B. старший викладач ORCID ID: https://orcid.org/0000-0002-5734-4352 Яременко А.М. здобувач освітнього ступеня «Магістр» Одеський торговельно-економічний інститут Київського національного торговельно-економічного університету, м. Одеса, Украӥна

\section{ФІНАНСОВА СТРАТЕГІЯ - ІНСТРУМЕНТ СТАБІЛІЗАЦІї ПІДПРИСМСТВА}

В умовах глобалізації та світової інтеграції зростає значення вирішення проблем, що пов'язані 3 ефективним управлінням та забезпеченням підприємствами необхідними фінансовими ресурсами. Тому в цьому випадку фінансова стратегія $є$ дієвим інструментом стратегічного управління процесами фінансової діяльності підприємства [1, с. 196]. На сьогодні ще досить повністю невизначено 
сутність фінансової стратегії в системі менеджменту підприємства, але можливо сформувати таке визначення категорії - комплексний план розвитку фінансової діяльності підприємства, що виражений у формуванні прибутку та його розподілу, рішеннях щодо структури капіталу, виборі форм інвестування та оптимізації оподаткування для досягнення найвищих результатів. Фінансова стратегія є основою розробки інших функціональний стратегій (маркетингової, кадрової, виробничої. Кожне підприємство має свої особливості, тому єдиного підходу щодо вибору або розробки фінансової стратегії не існує. Суб'єкт підприємницької діяльності самостійно формує таку фінансову стратегію, яка б мінімізувала ризики і сприяла збільшенню його прибутковості, підвищенню конкурентоспроможності та фінансової стійкості на ринку. Але є загальний алгоритм побудови фінансової стратегії, що відображено на рис. 1 [2, с. 162].

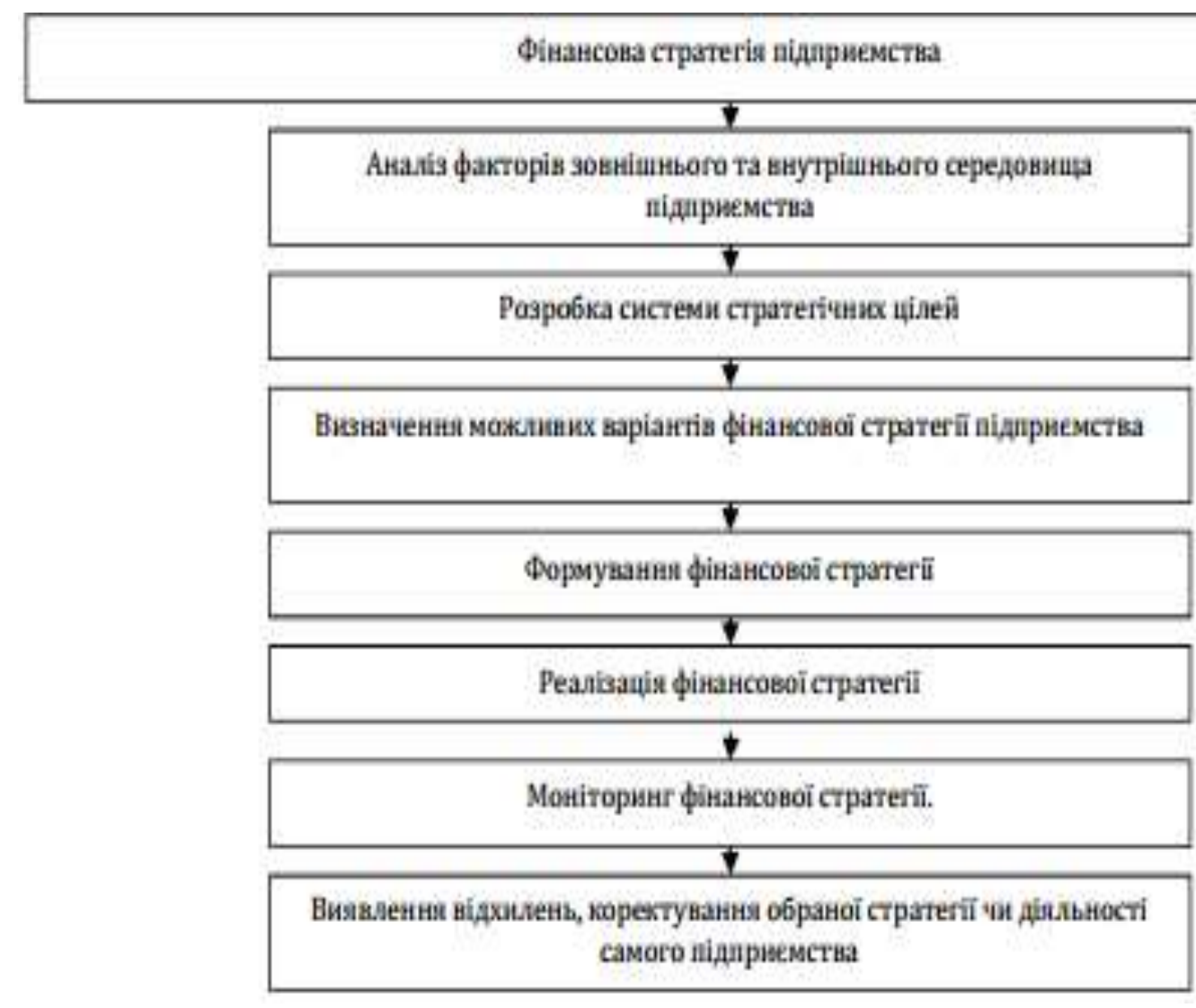

Рис. 1. Алгоритм побудови фінансової стратегії 
Інструментом, який дозволяє визначити, наскільки управління підприємством відповідає рівню досягнення стратегічних цілей, тобто зміцненню та росту ринкової вартості компанії є оцінка ефективності реалізації стратегії. В умовах нестабільного ринкового середовища доцільно диверсифікувати джерела фінансування інвестицій при реалізації фінансової стратегії розвитку підприємства, застосовуючи як внутрішні, так і зовнішні ресурси, з метою стабілізації фінансового стану підприємства.

\section{Список використаних джерел}

1. Буняк Н.М. Фінансова стратегія в системі менеджменту підприємства / Н.М. Буняк / Економіка і суспільство. - 2017. - Випуск 8. $-196 \mathrm{c}$.

2. Щербань О. Методичний підхід до розробки фінансової стратегії підприємства / О. Щербань // Економічний аналіз. - 2013. - Т. 12(4). - C. 161-165.

\section{СЕКЦІЯ 4}

\section{ФІНАНСОВА ІНКЛЮЗІЯ ТА ЗАХИСТ ПРАВ СПОЖИВАЧІВ ФІНАНСОВИХ ПОСЛУГ}

Аванесова I. A.

к.е.н., дочент

Київський національний торговельно-економічний університет,

м. Київ, Україна ORCID ID: http://orcid.org/0000-0001-7878-8254

\section{ФІНАНСОВА ІНКЛЮЗІЯ У ДОСЯГНЕННІ ЦІЛЕЙ СТАЛОГО РОЗВИТКУ}

Відомо, що фінансова інклюзія, це створення умов для залучення усіх сегментів споживачів до користування різними фінансовими послугами, які доступні за інфраструктурною ціною, офіційно 
урегульовані та відповідають фінансовим потребам споживачів 3 метою стимулювання економічного зростання економіки країни та зменшення соціальної нерівності у суспільстві. [1] Голова Національного банку України Яків Смолій уточнюе [2] розуміння фінансової інклюзії як рівний доступ всіх споживачів та використання ними фінансових послуг через доступний контакт із фінансовими посередниками, усвідомлений вибір споживачами фінансової послуги та гарантування якісного надання такої послуги третіми сторонами.

Отже, фінансова інклюзія, як убезпечене фінансове посередництво, має сприяти досягненню Цілей сталого розвитку (Sustainable Development Goals, SDGs) [3], які були ухвалені Генеральною асамблеєю Організації Об’єднаних Націй 25 вересня 2015 року з терміном дії - до 2030 року включно. Загальна мета досягнення сімнадцяти Цілей сталого розвитку, це забезпечення кращого та більш сталого майбутнього для всіх людей у світі. [4] Важливо, що всі Цілі сталого розвитку взаємопов'язані та охоплюють всі аспекти людського життя, а саме: відсутність бідності та голоду, гарне здоров'я та добробут, якісна освіта, родинна рівність, чиста вода та санітарія, доступна та чиста енергія, гідна праця та економічне зростання, промисловість- інновації та інфраструктура, зменшення нерівності, сталі міста та громади, відповідальне виробництво та споживання, кліматична активність, життя на землі та під водою, мирсправедливість та сильні інституції, партнерство задля досягнення цілей.

Відтак, фінансова інклюзія має забезпечити досягнення сімнадцяти Цілей сталого майбутнього при умові дотримання захисту прав та інтересів надавачів та споживачів фінансових послуг. 


\section{Список використаних джерел}

1. Фінансова інклюзія, Офіційне Інтернет представництво, Національний банк України. [Електронний ресурс]. - Режим доступу: https://bank.gov.ua/control/uk/publish/printable_article;jsessionid=C245F9 F181C5A617B3DD5D4E221B45CD?art_id=3961976\&showTitle $=$ true

2. Вітальне слово Голови НБУ Я.Смолія на Finclusion UA: Форум з фінансової інклюзії, м.Київ, 12.06.2018. [Електронний ресурс]. - режим доступу: https://bank.gov.ua/control/uk/publish/ printable_article;jsessionid=D4037130530F6AACBDDB984DDD8BF725 ?art_id=71600439\&showTitle=true

3. Leora Klapper, Achieving the sustainable development Goals. [Електронний ресурс]. - режим доступу: https://www.cgap.org/research/publication/achieving-sustainabledevelopment-goalsARE

4. About the sustainable development Goals. [Електронний pecypc]. - режим доступу: https://www.un.org/sustainabledevelopment/sustainable-developmentgoals/

Ануфрісва К. В. к.е.H., C.H.C. ДУ «Інститут економіки та прогнозування НАНУ»,

м. Київ, Украӥна ORCID ID: http://orcid.org/0000-0002-3179-8655

\section{ФІНАНСОВА ІНКЛЮЗІЯ В РЕАЛІЯХ МАЛОЇ ВІДКРИТОЇ ЕКОНОМІКИ}

Фінансова інклюзія аналізується у вимірах: пропозиції (доступу до фінансових послуг) - вартості користування, обсягу необхідного забезпечення у разі кредитування, доступу до відділень фінансових установ [1]; і попиту з огляду на освіченість, дохід та вік населення [2]. Фінансова інклюзія сприяє прискоренню соціо-економічного розвитку: здешевленню послуг та розширенню кредитування, 
залученню строкового інвестиційного ресурсу, зменшенню готівки поза банківською системою.

Специфічні умови окремої країни відіграють важливу роль при визначенні обмежень фінансової інклюзії та формуванні державної політики. Поширення фінансових послуг можливе за умови врегулювання захисту прав сторін і наявності реєстрів, що зменшують асиметрію інформації [1]; спрямування ресурсів у підприємства, які мають потенціал створення робочих місць; наявності спеціальних пропозицій відділень фінансових установ.

В Україні поширення фінансових послуг є меншим порівняно 3 подібними малими економіками Свропи («peers»): співвідношення банківських кредитів приватному сектору до ВВП становило 31,1\% у 2017 році порівняно з 38,6\% у 2016 році, а в «реers» середнє значення коливалось в рамках 45,3-47,3\%\% [3].

В реаліях малої економіки 3 власною національною валютою необхідно забезпечити дві «лінії захисту» - прав кредиторів і прав споживачів фінансових послуг. Законодавчі зрушення щодо захисту прав кредиторів в Україні в перспективі допоможуть знизити кредитні ризики банків і «підігріти» апетит до ризику, враховуючи, що частка непрацюючих кредитів на кінець 2017 року склала 54,5\%, а у «peers» становила 9,4\% [3]. Важливість захисту прав споживачів обумовлюється агресивною політикою банків, а також чутливістю національної валюти.

За відсотком населення, яке має банківські рахунки, Україна має менший рівень інклюзії; за кількістю банківських відділень на 100.000 чол. Україна має 0,4 відділення, серед «peers» - 10-50 [3].

Україна характеризуються недостатнім рівнем поширення фінансових послуг та фінансової інклюзії. Реанімація кредитування, 
зокрема МСП, підвищення фінансової грамотності населення, пропозиція банківських послуг для регіональних потреб сприятимуть розширенню фінансової інклюзії суб'єктів економіки.

\section{Список використаних джерел}

1. Dabla-Norris E., Ji Y., Townsend R., Unsal D.F. Identifying Constraints to Financial Inclusion and Their Impact on GDP and Inequality: A Structural Framework for Policy / IMF Working Paper No. 15/22. - 27 лютого 2015. - 49 с. - C. 42-44.

2. Tuesta D., Sorensen G., Haring A., Cámara N. Financial inclusion and its determinants: the case of Argentina / BBVA Research. Working Paper No. 15/03. - Січень 2015. - 28 с. - C. 3, 20.

3. The World Bank Data [Електронний pecypc]. - Режим доступу: https://data.worldbank.org/indicator/FD.AST.PRVT.GD.ZS ?view=chart.

Бортніков Г. П.

к.e.H. ДННУ «Академія фінансового управління»,

м. Київ, Україна

ORCID ID: https://orcid.org/0000-0001-8388-6721

\section{ОСВІТНІ ВКЛАДИ В УКРАЇНІ}

Підвищення фінансової грамотності та стимулювання заощаджень населення створює передумови для набуття вищої освіти, оскільки дозволяє акумулювати необхідні суми для оплати відповідних витрат на навчання. Одним 3 відносно новітніх фінансових інструментів у світі є освітні депозити. Основними відмінностями освітніх депозитів від класичних вкладів є мета (призначення), строки та додаткова винагорода для зберігачів за рахунок державного бюджету.

Наприклад, цільові депозити у рамках канадської схеми Registered Education Savings Plans (RESP) відкриваються у банках, небанківських фінансових установах (наприклад, страхових 
компаніях). Батьки або інший член сім'ї відкривають RESP-рахунок, визначаючи дитину бенефіціаром. Особа, яка відкриває рахунок, називається підписантом. Існує два типи RESP: (1) Індивідуальні плани: бенефіціар не пов'язаний $з$ підписантом; (2) Сімейні плани: можуть бути визначені декілька бенефіціарів, але всі вони повинні бути спорідненими особами підписанта. Кошти на RESP-рахунках не обкладаються податками до зняття. Цю схему доповнює Грант для освітніх заощаджень Канади (CESG), що складається з базової суми гранту та додаткової суми гранту. Базовий CESG, який був запроваджений у 1998 році, доступний для бенефіціарів незалежно від рівня доходу і складається з виплати 20\% на перші \$ 2500 особистих внесків, внесених до RESP щороку, аж до кінця календарного року, в якому бенефіціар досягає 17 років. Бенефіціари з сімей із середнім або низьким рівнем доходу також можуть претендувати на Додатковий грант у сумі 10\% або 20\% від перших 500 доларів особистих внесків, що вносяться державою щороку [1]. Інструмент «навчальних бондів» Канади (CLB) запроваджений у 2005 році для сімей з низьким рівнем доходу. Особисті внески не потрібні для отримання CLB. CLB надає початковий платіж у розмірі 500 доларів США та 100 доларів США на кожний рік права на вік до 15 років, до максимального розміру 2000 доларів США. На кінець 2017 року у Канаді понад 52\% дітей (або 3,7 млн осіб) отримали CESG [2].

Кошти з таких депозитних рахунків не можуть бути використані за нецільовим призначенням. «Освітній депозит» слід відмежовувати від депозитів депозитів, які вимагають від абітурієнтів університети у деяких країнах СС (підтвердження платоспроможності). Вигодами для банків, що приймають такі заощадження, є отримання довгострокових 
ресурсів. Розвиток культури заощаджень є одним з зовнішні ефектів даного фінансового інструменту.

\section{Список використаних джерел}

1. Canada Education Savings Program: 2017 Annual Statistical Review. $\quad$ - $\quad$ https://www.canada.ca/en/employment-socialdevelopment/services/student-financial-aid/educationsavings/reports/statistical-review.html.

2. Canada Education Savings Plan - 2017 Annual Statistical Review. - Canada.ca/publicentre-ESDC.

Брус C. I. к.е.н., старший науковий спіробітник ДУ «Інститут економіки та прогнозування НАН Украӥни» м. Київ, Україна

\section{ОЦІНКА ФІНАНСУВАННЯ КОРПОРАТИВНОГО СЕКТОРУ ІНСТИТУТАМИ СПІЛЬНОГО ІНВЕСТУВАННЯ}

Оцінюючи стан та рівень розвитку вітчизняного ринку спільного інвестування (далі - ICI) необхідно відзначити наступні його особливості:

1) за загальним ресурсним потенціалом індустрія спільного інвестування посідає друге місце серед фінансових установ (після банківського сектору) та перше місце серед небанківських фінансових установ, а за обсягами інвестицій у реальний сектор економіки вдвічі перевершує банківську сферу;

2) домінуючі позиції серед ICI обіймають венчурні фонди, які зосереджують 95 відсотків загальної вартості інвестиційних активів, хоча вони не є класичними інститутами спільного інвестування, які функціонують на міжнародних ринках капіталу;

3) основною причиною існування псевдо венчурних фондів в Україні є та, що, на відміну від класичних ICI, вітчизняні фонди 
створюються і функціонують як інститути фінансового посередництва, які не слугують для взаємозв'язку між інвестором та емітентом, але, як правило, або пов'язані між собою відносинами контролю, або взагалі представлені однією й тією ж особою.

За період з 2014 по 2017 роки частка вкладень ICI в акції та корпоративні облігації лише скорочувалася по усіх видах фондів. Найзначніше падіння вкладень в акції спостерігалося по невенчурним інститутами спільного інвестування. Частка акцій у їх портфелі зменшилася у 2,6 рази з 45,76 у 2014 році до 17,61\% у 2017. Венчурні фонди скорочували свій портфель акцій не так стрімко (у 1,9 рази), але їх частка у портфелі від початку була лише 15,05\%. В загальному ICI скоротили свою частку вкладень в акції з 16,6 до 8,7\%.

Скорочення вкладень в облігації підприємств відбувалося не так стрімко, але їх доля була досить незначна на рівні 3-4\% по усім групам фондів. В загальному за період з 2014 по 2017 роки вартість активів вкладених в облігації скоротилася на 1\% по венчурних фондах та на 0,22 по іншим групам ICI.

Структурно активи за усіма групами фондів ICI за останні роки були перерозподілені на користь «дебіторської заборгованості». Капітал венчурних компаній в Україні не слугує, як це прийнято в світовій практиці, для фінансування ризикових інвестиційних проектів. Основне призначення венчурних фондів - оптимізація бізнесу корпорацій та підприємств.

Потрібно зазначити, що на даний момент викривлення накопичення інвестиційних ресурсів ICI венчурними фондами свідчить про те, що багато потенційних емітентів цінних паперів мають обмежений доступ до такого ресурсу. В основному коштами ICI можуть користуватися засновники венчурних фондів та позичальники, 
що афілійовані з ними.

\section{Список використаних джерел}

1. Аналітичний огляд індустрії управління активами в Україні Результати 4-го кварталу та всього 2016 року, с. 14-16 // Українська асоціація інвестиційного бізнесу [Електронний ресурс]. - Доступний 3 :

http://www.uaib.com.ua/files/articles/2561/48/Q4\%202016\%20\&\%20Full $\% 202016 \_f i n a l . p d f$

Вінська О. Й.

к.е.н., доиент

ORCID ID: https://orcid.org/0000-0002-4360-0933

Токар В. В.

d.e.н., npoфpecop

ORCID ID: https://orcid.org/0000-0002-1879-5855 ДВНЗ «Київський національний економічний університет імені Вадима Гетьмана», м. Київ, Украӥна

\section{ЗМЕНШЕННЯ ГЕНДЕРНОГО РОЗРИВУ В СС: ФІНАНСОВИЙ АСПЕКТ}

Емансипація жінок є глобальним трендом сьогодення, який стрімко розвивається та набуває нових форм. Усі провідні міжнародні організації та регіональні об’єднання визначають досягнення гендерної рівності як один 3 ключових пріоритетів свого функціонування. Зокрема, гендерний розрив в країнах-членах СС у доступі до фінансів скоротився у середньому на 20\% упродовж 2005-2015 рр. Усі країни продемонстрували позитивні результати у цій царині, окрім Об'єднаного Королівства та Греції, де розрив незначно збільшився. Люксембург майже повністю викорінив нерівність у доступі жінок та чоловіків до фінансового ресурсу, а такі країни як Бельгія, Данія та Швеція швидко наближаються до гендерної рівності в цій царині. Лідерами є Болгарія (43,9\%) та Словаччина (40,6\%), підтверджуючи 
позитивний вплив європейської інтеграції на розширення економічних прав та можливостей жінок (таблиця).

Таблиия

Фінансовий аспект гендерного розриву в країнах-членах ЄС у

2005 i 2015 pp.

\begin{tabular}{|c|c|c|c|c|}
\hline Країна & 2005 & 2015 & Абсолютна зміна & Відносна зміна, \% \\
\hline Люксембург & 91,2 & 97,0 & 5,8 & 6,4 \\
\hline Бельгія & 73,9 & 82,7 & 8,8 & 11,9 \\
\hline Данія & 71,2 & 82,4 & 11,2 & 15,7 \\
\hline Швеція & 72,2 & 82,3 & 10,1 & 14,0 \\
\hline Німеччина & 73,7 & 81,2 & 7,5 & 10,2 \\
\hline Ірландія & 73,6 & 81,0 & 7,4 & 10,1 \\
\hline Франція & 71,4 & 80,4 & 9,0 & 12,6 \\
\hline Австрія & 71,9 & 79,8 & 7,9 & 11,0 \\
\hline Нідерланди & 72,6 & 79,1 & 6,5 & 9,0 \\
\hline Фінляндія & 67,9 & 78,5 & 10,6 & 15,6 \\
\hline Об’єднане Королівство & 77,1 & 77,0 & $-0,1$ & $-0,1$ \\
\hline Мальта & 53,0 & 73,3 & 20,3 & 38,3 \\
\hline Італія & 68,0 & 73,0 & 5,0 & 7,4 \\
\hline Кіпр & 60,5 & 72,1 & 11,6 & 19,2 \\
\hline Іспанія & 63,5 & 71,0 & 7,5 & 11,8 \\
\hline Словенія & 62,9 & 69,8 & 6,9 & 11,0 \\
\hline Греція & 62,2 & 61,4 & $-0,8$ & $-1,3$ \\
\hline Польща & 46,2 & 61,4 & 15,2 & 32,9 \\
\hline Португалія & 58,0 & 60,3 & 2,3 & 4,0 \\
\hline Чехія & 50,6 & 58,8 & 8,2 & 16,2 \\
\hline Хорватія & 56,2 & 57,1 & 0,9 & 1,6 \\
\hline Естонія & 41,4 & 56,4 & 15,0 & 36,2 \\
\hline Словаччина & 40,1 & 56,4 & 16,3 & 40,6 \\
\hline Угорщина & 47,3 & 55,2 & 7,9 & 16,7 \\
\hline Литва & 40,7 & 53,5 & 12,8 & 31,4 \\
\hline Латвія & 40,2 & 51,9 & 11,7 & 29,1 \\
\hline Болгарія & 33,5 & 48,2 & 14,7 & 43,9 \\
\hline Румунія & 36,1 & 45,7 & 9,6 & 26,6 \\
\hline Середнє значення & 59,9 & 68,8 & 8,9 & 17,2 \\
\hline EC-28 & 60,9 & 73,0 & 12,1 & 19,9 \\
\hline
\end{tabular}

Джерело: власні розрахунки на основі [1]

\section{Список використаних джерел}

1. Gender Equality Index 2017: Money Comparing in Money / Financial Resources [Електронний ресурс] - Режим доступу: 
https://eige.europa.eu/gender-equality-index/2005/countriescomparison/money/1/table.

Жураховська Л. В.

к.е.н., МВА, доиент

Київський національний торгівельно-економічний університет

м. Київ, Украӥна

ORCID ID: https://orcid.org/0000-0003-3745-0155

\section{СПРАВЕДЛИВА ОЦІНКА РЕПУТАЦІЇ БАНКУ ЯК ЗАХИСТ ПРАВ IHBECTOPIB}

В умовах падіння довіри до банків в останнє десятиліття в Україні фактор репутації для банків є найважливішим у розвитку бізнес моделі. Проте, транспарентність інформації релевантної для оцінки репутації банків є критичною для захисту прав інвесторів.

Нині рівень конкуренції на ринку банківських послуг зростає, i гравці домагаються успіху шляхом збільшення довіри до свого бренду не тільки у споживача та інвестора, але й у регулятора ринку.

Так, згідно нового Положення про ліцензування банків №149, оцінка ділової репутації юридичних і фізичних осіб є однією з ключових нововведень у переході «від формалістичного до ризик-орієнтованого підходу в питаннях ліцензування банків» [1].

Проте сучасні дослідження ризику ділової репутації банків України мають здебільшого описовий характер, вивчаючи підходи до оцінки [2], [3].

В якості альтернативного підходу до розкриття інформації з оцінки репутації банків можна розглядати ранжування банків за оцінкою інвестиційних експертів. Так, згідно дослідження "Goodwillфактор" групи компаній NOKs Fishes, репутація банку оцінюється: 
а) трьома експертними групами - «фінансові журналісти», «регулятори ринку» і «фінансові аналітики»; б) в трьох площинах: експертна обізнаність про діяльність банківських установ, експертне схвалення діяльності банків та інтегральний репутаційний рейтинг; в) в кожній 3 площин аналіз проводиться в розрізі п'яти репутаційний блоків: «Маркетинг», «Продукт», «Бізнес», «Зовнішні комунікації» і «Внутрішні комунікації» [4]. Дослідники дійшли висновку, що одним 3 оптимальних інструментів формування репутації $\epsilon$ чітке позиціонування бренду банку і системне інформування стейкхолдерів про сильні сторони ринкової представленості бренду, а також корекція негативних інформаційних потоків щодо недоліків цього бренду.

3 нашої точки зору математична оцінка репутаційного ризику може розраховуватися як дисперсія оцінок за період.

\section{Список використаних джерел}

1. Національний банк здійснив комплексний перегляд процесів ліцензування банків: Прес-реліз НБУ 28.12.2018 [Електронний документ]. - Режим доступу: https://bank.gov.ua/control/uk/publish/printable_article?art_id=84803880\& show Title $=$ true

2. К. Г. Гончарова. Особливості оцінки рівня ділової репутації топ-менеджменту банку в банківських установах України // Ефективна економіка. - № 5. - 2015 [Електронний документ]. - Режим доступу: http://www.economy.nayka.com.ua/?op=1\&z=4867

3. Торяник Ж.І., Шутілова О.О. Ділова репутація банку: сутнісна характеристика та особливості управління [Електронний документ]. http://ujae.tneu.edu.ua/index.php/ujae/article/download/142/142

4. Репутационное исследование банковского рынка Goodwillфактор / NOKs Fishes [Електронний документ]. - Режим доступу: https://www.favor.com.ua/ru/blogs/22503.html 
Клапків Ю. М.

к.е.н., доиент

Тернопільський начіональний економічний університет, м. Тернопіль, Україна

\section{РАЦІОНАЛЬНІСТЬ ТА ІРРАЦІОНАЛЬНІСТЬ СПОЖИВАЧА СТРАХОВОї ПОСЛУГИ}

Страхові послуги відносяться до інструментів, що відповідають за задоволення однієї з основних потреб людини, а саме в потреби в безпеці. В сучасному світі ця потреба реалізується через підтримання стабільності соціального рівня сім’ї та майнового стану. Згідно 3 ієрархією потреб, А. Маслоу потреба в безпеці розміщена на другій позиції піраміди потреб одразу після фізіологічних. Окрім того страхові послуги певною мірою кореспондують із наступними потребами як елемент підтримання відповідного рівня в суспільстві.

Теоретично, фізична особа повинна прагнути до придбання різноманітного страхового захисту, як інструменту, що дозволяють йому керувати певними ризиками, які їй загрожують [1]. Реалізація ризику може принести негативні наслідки, що впливають як на майновий стан, так і на перспективи функціонування сім'ї чи фірми.

На практиці, ситуація виглядає дещо по-іншому. Фізичні особи, в основному, набувають страхові послуги із обов'язкових видів страхування, домінуючим із яких є страхування цивільно-правової відповідальності власників наземних транспортних засобів. Такі страхові послуги купляються в зв'язку 3 існуванням страхового примусу і займають лідируючи позиції в витратах клієнтів на страховий захист. 
Схильність до набуття страхового захисту із добровільних видів страхування, грунтується на основі діагностики потреб покупців але залежить від багатьох чинників [2]. Вважається, що передусім від економічних, таких як вартість страхової послуги та доходи споживачів, але неекономічні чинники - такі як ставлення до ризику, втрат чи сприйняття часу, також обумовлюють попит на страхові послуги [3].

Значний відсоток рішень про придбання страхової послуги, має місце під впливом емоцій, як позитивних, таких як захват чи радість викликана можливістю володіти чи отримувати. Емоційна складова часто домінує при дистрибуції накопичувального страхування життя, що використовується і недобросовісними фінансистами. Водночас, не менш важливу роль відіграють і такі емоції як, страх чи занепокоєння про майбутнє.

Саме ці емоції випереджують раціональні міркування та визначають дії чи бездіяльність споживача. Адже, значний відсоток рішень приймаються ірраціонально. Вважається, що сучасна людина живе в суспільстві ризику та є більше емо-сапієнс (людина емоційна), ніж людина розумна (homo sapiens) [4]. Поведінкова економіка визначає імпульсивну поведінку найбільш типовою для фізичної особи, а не свідомий вибір, адже дія відбувається під впливом моменту. А жоден момент не можна вважати повністю раціональним [5].

При розгляді споживача як раціональної особистості, слід врахувати і значення емоції, в першу чергу страху чи тривожності, або навіть гніву [6]. Емоції можуть мати істотний вплив на прийняття рішення при укладанні страхового договору [7]. Люди, поставши перед певним вибором, шукають у своїй пам'яті факти і ситуації, які могли б бути актуальними для прийняття поточного рішення[8]. 
Такий підхід, проявляється при зростанні інтересу клієнтів до страхових продуктів, що захищають їх від обраного ризику одразу після реалізації цих ризиків у їх інформаційному просторі чи серед близьких їм осіб. Часто цього досить для суб'єктивно визнання загрози. В свою чергу, це призводить до ситуації за якої малоймовірна подія зосереджує на собі основну увагу. Клієнт же надає більшу вагу реалізованим збиткам що потрапили в його інформаційний простір, ніж це ризикам що мають вищу імовірність у його ситуації.

Підводячи підсумок, можна зробити висновок, що підхід до споживача, як до людини розумної, всі дії якої спрямовані на задоволення потреб і прагнення до досягнення максимальної вигоди із своїх рішень та обраних альтернатив є мало ефективним. Обумовлено це відсутністю комплектної інформації щодо реальних загроз та обмежені пізнавальні можливості в умовах невизначеності, в яких живе і приймає рішення покупець.

Отже, що рішення щодо набуття страхової послуги приймаються як під впливом раціональних чинників, як і нераціональних. Поряд із економічними факторами, такими як вартість страхового захисту i доходами споживачів, важливими є такі аспектів, як поінформованість про загрози, сприйняття часу та страхова свідомість, які і визначають поведінку споживачів на ринку страхових послуг.

\section{Список використаних джерел}

1. Клапків Л. М. Біхевіористична теорія на страховому ринку //Формування ринкових відносин в Україні. - 2016. - № 8. - С. 31-34.

2. Kaigorodova G., Alyakina D., Pyrkova G., Mustafina A. and Trynchuk V. Investment activity of insurers and the state economic growth //Montenegrin Journal of Economics. - Vol. 14. - №4. - 2018. - C.109-123.

3. Клапків Ю. Спрямування інституціонального розвитку ринку страхування життя в Україні [Текст] // Світ фінансів. - 2016. - Вип. 1. - C. 206-214. 
4.Katona G. Psychological Economics. Amsterdam-London-New York: Elsevier Scientific Publishing Company. - 1975.

5. Wicka A., Świstak J. "Homo sapiens oeconomicus, Homo oeconomicus - czy ubezpieczenia kupujemy w oparciu o tylko racjonalne czynniki?". Finanse, Rynki Finansowe, Ubezpieczenia. - № 5 (2). - S.403411.

6.Черняк Я., Клапків Л. Детермінанти розвитку інновацій у страховому бізнесі // Інноваційна економіка. - 2018. - №1-2. - С.182 188.

7.Тринчук В. В. Особливості збутової політики компаній 3 страхування життя // Вісник Київського національного університету імені Тараса Шевченка. Економіка. - 2009. - Вип. 113-114. - С. 35-39.

8. Кукурудз О., Попова М., Тринчук В. Літературний product placement як метод впливу на цільову аудиторію страховика //Финансовые услуги. - 2017. - № 5. - С. 24-31.

Котенко У. М. старший викладач Київський національний торговельно-економічний університет, м. Київ, Украӥна ORCID ID: http://orcid.org/0000-0002-5076-854X

\section{ФІНАНСОВА ІНКЛЮЗІЯ В УКРАЇНІ : ПЕРЕДУМОВИ ЗРОСТАННЯ}

Ступінь залучення населення у фінансові процеси вже давно стало явищем, що активно досліджується. Тривалий час для України це було не актуальним у зв'язку з низьким рівнем доходів населення та масштабними тіньовими процесами. Проте регіональна наближеність до розвинених європейських країн та активізація участі нашої країни у глобалізаційних процесах сприяють переосмисленню сприйняття фінансової інклюзії.

Підвищення рівня фінансової інклюзії є важливим для різних стейкхолдерів: для регуляторів та держави загалом; для провайдерів 
фінансових послуг; для споживачів. Фінансова інклюзія сприяє підвищенню та стабілізації доходів, ефективнішому управлінню активами, зменшенню вразливості від економічних криз [1].

Проте ціла низка причин продовжує стримувати фінансову активність населення. Низький рівень доходів, а також негативний досвід розв'язання проблем з фінустановами під час загострення економічних криз в Україні призвели до зниження привабливості банківських депозитів. Саме цей вид фінансових послуг вважався найзрозумілішим, найпростішим у використанні для різноманітних верств населення.

Розвиток безготівкових розрахунків безумовно $є$ перспективним напрямком. Проте й у цій сфері $є$ проблеми, що не сприяють позитивній реакції суспільства. Це і постійно оновлювальні шахрайські схеми, і проблеми інфраструктурного характеру, і втрата одноосібного контролю за власними фінансами, тощо.

Кредитні послуги є ще одним 3 найрозповсюдженіших видів фінансових послуг на вітчизняному просторі. Проте при наявності високого попиту на додаткові ресурси населення масово не використовує кредитні кошти у повсякденному житті. Цьому не сприяють економічна та політична нестабільність 3 неможливістю прогнозування майбутніх статків, юридична незахищеність, вартість послуги, тощо.

При інклюзії всі зацікавлені сторони повинні брати активну участь для отримання бажаного результату, а, отже, необхідно зосередити увагу на наступних напрямках:

- створювати фінансові послуги, які доступні за інфраструктурою та ціною, офіційно урегульовані та відповідають потребам населення; 
- формувати та розвивати дієву та просту системи захисту прав споживачів;

- продовжувати запроваджувати диференційовані заходи 3 підвищення фінансової грамотності українців;

- розвивати цивілізовану безготівкову економіку.

\section{Список використаних джерел}

1. Офіційний сайт НБУ [Електроний ресурс]. - Режим доступу : http://www.bank.gov.ua.

Krivoruchko S. Doctor on Economic Science, Professor, Financial University, Moscow, Russia ORCID ID: http://orcid.org/0000-0002-6618-3095

\section{IMPACT OF REMITTANCES ON ECONOMIC GROWTH}

The author considered the geography of cross-border remittances between countries emerged after the collapse of the former Soviet Union (FSU). These countries have been forming a unique network of transborder remittances and labor migration flows. The author detected clear relationship between the level of economic development and volume of inflows (remittances received).

The analysis highlighted a significant discrepancy in the ratio of outgoing and incoming transfers by several countries depending on economic development. The level of financial inclusion (coverage of financial services and products) is a determining factor in the use of official remittance channels. To prove this thesis, we compared the World Bank data The Global Financial Inclusion Database for FSU countries (see Table). 
Percentage of the adult population (persons 15 years and older) according to the results of surveys, $\%$

\begin{tabular}{|l|c|c|}
\hline \multicolumn{1}{|c|}{ Country } & Holder of Account in the bank & Receiver of remittances \\
\hline Estonia & 98 & 16 \\
\hline Latvia & 93 & 19 \\
\hline Lithuania & 83 & 22 \\
\hline Belarus & 81 & 23 \\
\hline Russia & 76 & 21 \\
\hline Ukraine & 63 & 15 \\
\hline Georgia & 61 & 15 \\
\hline Kazakhstan & 59 & 18 \\
\hline Tajikistan & 47 & 21 \\
\hline Armenia & 45 & 23 \\
\hline Moldova & 44 & 17 \\
\hline Turkmenistan & 41 & 22 \\
\hline Kyrgyzstan & 38 & 25 \\
\hline Uzbekistan & 37 & 8 \\
\hline Azerbaijan & 29 & 17 \\
\hline
\end{tabular}

Source: Demirgüç-Kunt, Asli, Leora Klapper, Dorothe Singer, Saniya Ansar, and Jake Hess. 2018 [1]

By geography of cash inflows [2] we identified specific groups of countries by the share of transfers from Russia in total inflows: (1) countries with a very high dependence (over 75\%): Kyrgyzstan, Tajikistan, Turkmenistan, Uzbekistan; (2) countries with higher dependence (40-75\%): Armenia, Azerbaijan, Belarus, Georgia, Kazakhstan, Ukraine; and (3) countries with moderate dependence (less than 40\%): Estonia, Latvia, Lithuania, Moldova. Volume of remittance in Ukraine and Moldova are underestimated due to alternative channels for transferring money, as well as bans on working in Ukraine for Russian operators and banks, which gives grounds to consider the amount of money transfer to Ukraine understated by no less than half.

\section{References}

1. Demirgüç-Kunt, Asli, Leora Klapper, Dorothe Singer, Saniya Ansar, and Jake Hess (2018). - The Global Findex Database 2017. 
2. Bilateral Migration Matrix (2018). - URL: http://www.worldbank.org/en/topic/migrationremittancesdiasporaissues.

Міщенко С. В.

д.е.н., nрофесор

ORCID ID: https://orcid.org/0000-0002-1840-8579

Дорофесв Д. А. аспірант

ORCID ID: https://orcid.org/0000-0002-3447-3688 ДВНЗ «Університет банківської справи», м. Київ, Україна

\section{ЕТАПИ ІННОВАЦІНОГО РОЗВИТКУ НЕБАНКІВСЬКОГО ВІТЧИЗНЯНОГО ФІНАНСОВОГО СЕКТОРУ}

Формування небанківського фінансового сектору України, як важливої системної фінансової інновації, розпочалося в 1991 р. і за цей час пройшло кілька важливих етапів. Перший етап - 1991-1999 р. характеризувався початком діяльності інвестиційних фондів і компаній (1994 р.), створенням довірчих товариств (1993р.), відновленням діяльності кредитних спілок, прийняттям Закону України «Про страхування» (1996р.), започаткуванням лізингових операцій (1997 р.). Упродовж цього періоду було закладено інституційні засади небанківського фінансового сектору.

Другий етап - 2000-2008 pp. характеризується збільшенням кількості небанківських фінансових установ і зростанням їх активів. Прийнято Закон України «Про фінансові послуги та державне регулювання ринків фінансових послуг» (2001р.), врегулювано діяльність кредитних спілок та факторингових компаній, створено ICI, розпочали роботу недержавні пенсійні фонди (2003р.), створено Фонди операцій з нерухомістю (2003 р.), запроваджено електронні 
гроші (2008 р.) [1]. 3 точки зору використання фінансових інновацій цей етап можна характеризувати як період екстенсивного розвитку [2, c. 394].

Третій етап - 2009-2013 pp. - створення Національної комісії, що здійснює державне регулювання у сфері ринків фінансових послуг, розширено ऑї функцій, змінено принципи діяльності факторингових компаній та ICI, започатковано послугу - адміністрування фінансових активів у групах, створено небанківські платіжні системи [3, с. 24].

Четвертий етап - період 32014 р. і до теперішнього часу характеризується уповільненням розвитку небанківського фінансового сектору, зменшенням кількості кредитних спілок, недержавних пенсійних фондів і страхових компаній та збільшенням кількості фінансових компаній, підвищенням рівня концентрації капіталу, а також підготовкою до реформування системи регулювання діяльністю небанківських фінансових установ. Цей етап можна охарактеризувати як перехід до інтенсивного типу використання інновацій [2, с. 395].

\section{Список використаних джерел}

1. Світовий досвід і перспективи розвитку електронних грошей в Україні. Вип. 10 / П.М. Сенищ, ін. - К.: ЦНД НБУ, 2008. - 145 с.

2. Науменкова С.В. Особливості регуляторної ідентифікації фінансових компаній як фінансових посередників / С.В. Науменкова, С.В. Міщенко, В.I. Міщенко // Фінансово-кредитна діяльність: проблеми теорії та практики. - 2019. - №1(28). - С.390-401.

3. Міщенко С. Вдосконалення системи безготівкових роздрібних платежів / С. Міщенко // Вісник Київського національного університету імені Тараса Шевченка. - 2014. - №5(158). - С.22-28. 


\section{Пожидаєва М. А.}

к.ю.н, доиент,

Навчально-науковий інститут «Юридичний інститут ДВНЗ «Київський національний економічний університет імені Вадима Гетьмана»,

м. Київ, Украӥна ORCID ID: http://orcid.org/0000-0003-2355-1131

\section{ЩОДО ПИТАННЯ НЕВИКОНАННЯ АБО НЕНАЛЕЖНОГО ВИКОНАННЯ ПЛАТІЖНОГО ДОРУЧЕННЯ НА ПЕРЕКАЗ КОШТІВ ДО БЮДЖЕТУ}

Вивчаючи практику Верховного Суду щодо вирішення адміністративних справ у сфері неналежної сплати та несвоєчасного перерахування податкових платежів до бюджетів, слід звернути увагу на окремі випадки, у разі настання яких платник податків не несе відповідальності за порушення строків зарахування останніх до бюджетів (наприклад, справа № 803/1054/17 від 28.08.2018, справа №823/1985/17 від 07.09.2018, справа № 806/68/16 від 19.02.2019, які розглядались Верховним Судом у складі колегій суддів Касаційного адміністративного суду щодо питання відповідальності платника за дії банківських установ, а також учасників подальшого перерахування податкових платежів) $[1,2,3]$. Актуальність розгляду даної проблеми обумовлена тим, що за несвоєчасне зарахування сум податкових платежів на єдиний казначейський рахунок податкові органи переважно застосовують саме до платників податків штрафні санкції та нараховують пеню незалежно з чиєї вини відбулося неповне внесення чи невнесення податків/зборів/єдиного соціального внеску до відповідних бюджетів чи позабюджетних цільових фондів. 
На жаль, податкові органи не розмежовують такі поняття, як «сплата податку» та «зарахування податку», а також не враховують багатостадійний процес сплати та переказу коштів до бюджету. У зв'язку з цим ДФС України, використовуючи норми ч. 5 ст. 45 і ч. 5 ст. 78 Бюджетного кодексу України, займає несправедливу позицію, згідно з якою податкове зобов'язання вважається виконаним тільки 3 моменту зарахування сплаченої суми на єдиний казначейський рахунок [4, с. 5].

Проте, згідно $з$ п. 8.1 ст. 8, п. 22.4 ст. 22 Закону України «Про платіжні системи та переказ коштів в Україні» від 05.04.2001 конституційний обов'язок платника зі сплати податкових платежів (ст. 67 Конституції України) слід вважати виконаним з дати подання до обслуговуючого банку платіжного доручення на переказ до бюджету грошових коштів з рахунку платника в банку за наявності в нього достатнього грошового залишку на день платежу. Водночас, потрібно зауважити, що у переказі та зарахуванні таких сум на єдиний казначейський рахунок платник уже безпосередньої участі не бере. Тому після прийняття банком розрахункового документа (платіжного доручення) на виконання платник не несе відповідальності за дії банку, який здійснює переказ коштів. При цьому банки забезпечують фіксування дати прийняття розрахункового документа на виконання.

Отже, за наявності в платника відповідних доказів, що підтвердять виконання всіх передбачених законодавством умов для визнання його добросовісним платником, обов'язок зі сплати відповідної суми податкового (грошового) зобов'язання слід визнати виконаним, незалежно від фактичного зарахування платежу до бюджетної системи України. Такого справедливого правового висновку дотримується у своїх рішеннях Верховний Суд. 
У той же час, відповідно до п. 22.9 і п. 22.10 ст. 22 , п. 27.2 ст. 27 зазначеного вище Закону, внутрішніх актів банку, укладених договорів між банком та клієнтами банк не відповідає за невиконання доручення клієнта у разі неправильного зазначення або несвоєчасного повідомлення про зміну реквізитів одержувача, а також за відсутності коштів на картці/рахунку клієнта. Тому відсутність на рахунку клієнта коштів, достатніх для виконання платіжного доручення, є підставою для його невиконання банком. Відповідно, у такому випадку неперерахування податку не є наслідком винних дій банку, а тому відповідальність за своєчасність та повноту його сплати покладається на платника податків, який ініціював відповідний грошовий переказ. Таку правильну правову позицію зайняв Верховний Суду у складі колегії суддів Касаційного адміністративного суду у своїй постанові 3 розгляду справи № 808/9458/14 від 07.02.2018 р. [5].

Водночас, суперечливою $є$ позиція ДФС України щодо податкового боргу платника податків, який виник з вини банку через порушення останнім строків зарахування податків і зборів до бюджетів у зв'язку із збоями в його роботі (наприклад, введення тимчасової адміністрації) [6]. Такий борг залишається за цим платником податків і підлягає перерахуванню ним до бюджету. ДФС України зазначає, що незважаючи на причину несплати податкових зобов'язань, зокрема, у разі порушення банком строків виконання або невиконання доручень клієнтів на переказ коштів, платник податків не звільняється від обов'язку сплатити основну суму податкового зобов'язання або податкового боргу, а податковий орган, відповідно, від стягнення такого податкового боргу та/або від зарахування платежів, здійснених через установи інших банків. 
Підсумовуючи викладене вище та враховуючи позитивну судову практику, можна зробити висновок, що грошове зобов'язання зі сплати податкового платежу вважається належним чином виконаним з боку платника після одержання платіжного доручення банком за умови наявності у цього платника достатнього грошового залишку на день платежу. Тому платник податків не несе відповідальності за дії банку та звільняється від відповідальності за несвоєчасне перерахування або не в повному обсязі податків, зборів та інших платежів до бюджетів та позабюджетних цільових фондів, включаючи нараховані штрафні санкції та/або пеню.

\section{Список використаних джерел}

1. Категорія справи №803/1054/17: Адміністративні справи (до 01.01.2019); справи зі спорів з приводу реалізації податкової політики та за зверненнями податкових органів із деякими видами вимог, зокрема зі спорів щодо адміністрування окремих податків, зборів, платежів, у тому числі акцизного податку. Дата набрання законної сили: 28.08.2018. Оприлюднено: 10.09.2018. URL: http://reyestr.court.gov.ua/Review/76307127

2. Категорія справи №823/1985/17: Адміністративні справи (до 01.01.2019); Старі категорії (адм); збору та обліку єдиного внеску на загальнообов'язкове державне соціальне страхування. Дата набрання законної сили: 07.09.2018. Оприлюднено: 10.09.2018. URL: http://reyestr.court.gov.ua/Review/76307055

3. Категорія справи №806/68/16: Адміністративні справи (до 01.01.2019); справи зі спорів з приводу реалізації податкової політики та за зверненнями податкових органів із деякими видами вимог, зокрема зі спорів щодо адміністрування окремих податків, зборів, платежів, у тому числі податку на додану вартість (крім бюджетного відшкодування з податку на додану вартість). Дата набрання законної сили: 19.02.2019. Оприлюднено: 20.02.2019. URL: http://reyestr.court.gov.ua/Review/79957722

4. Податок вважають сплаченим 3 дня зарахування на єдиний казначейський рахунок: лист Державної фіскальної служби України від 13.08.2014 p. № 1128/5/99-99-20-03-01-16. Податки та бухгалтерський облік. 2014. № 94. С. 5. 
5. Категорія справи №808/9458/14: Адміністративні справи (до 01.01.2019); Старі категорії (адм); реалізації податкового контролю. Дата набрання законної сили: 07.02.2018. Оприлюднено: 09.02.2018. URL: http://reyestr.court.gov.ua/Review/72089383

6. Про порушення строків зарахування податків i зборів до бюджетів: лист Державної фіскальної служби України від 24.01.2017 p. № 1575/7/99-99-12-03. URL: http://kr.sfs.gov.ua/media-ark/newsark/284145.html

Ховрак I. В.

к.е.н., доиент

Кременчуцький національний університет імені М. Остроградського, м. Кременчук, Україна ORCID ID: http://orcid.org/0000-0002-0352-4374

\section{СОЦІАЛЬНА ВІДПОВІДАЛЬНІСТЬ УСТАНОВ ТА ІІЇ ВПЛИВ НА ЛОЯЛЬНІСТЬ СПОЖИВАЧІВ ФІНАНСОВИХ ПОСЛУГ}

Сучасний ринок фінансових послуг характеризується швидкими темпами глобалізації, значним рівнем конкуренції між компаніями, динамічними змінами інфраструктури та технологій надання послуг, зростанням видів фінансових інструментів тощо. Все це змушує компанії перенести фокус уваги з виключно власної ефективності та споживачів, їх інтереси та потреби, рівень задоволеності та лояльності.

Поведінка та потреби споживача фінансових послуг не $\epsilon$ усталеними, мають схильність до постійних змін. Саме тому формування і підтримку лояльності споживачів варто здійснювати в межах системних і комплексних програм. При цьому основними етапами процесу розроблення програми лояльності споживачів $\epsilon[1, \mathrm{c}$. 65]: організаційно-управлінський (створення команди та збір бази даних, визначення мети та завдань); інформаційно-методологічний 
(вибір ключових факторів та виду програми, формування системи маркетингових комунікацій); фінансово-економічний (розрахунок бюджету програми); контрольно-коригувальний (оцінка результатів програми, коригувальні заходи). Щоб залишатися актуальними та завоювати лояльність у цифровій економіці, компанії повинні використовувати дані про споживачів, щоб забезпечити гіперрелевантний, зручний та надійний досвід роботи з клієнтами [2, с. 48].

На формування лояльності споживачів фінансових послуг впливають різноманітні соціально-демографічні (вік, стать, соціальний статус, склад сім'ї, національність), емоційні (досвід співпраці та довіра до компаній, реклама та маркетингова політика компаній, захоплення та стиль життя споживача) та раціональні фактори (якість та вартість фінансових послуг, місце розташування компанії, кваліфікація персоналу, інноваційні технології).

Соціальна відповідальність компаній вимагає особливої уваги, оскільки вона може одночасно впливати як на емоції споживачів, так i на логіку в процесі прийняття рішень щодо вибору компанії. Соціальна відповідальність здатна збільшити капіталізацію компаній, забезпечити їм конкурентну перевагу, узгодити інтереси влади, бізнесу та суспільства [3, с. 391], щоб в результаті забезпечить лояльність споживачів фінансових послуг. Відповідно, соціальна відповідальність компаній сприяє формуванню довгострокових взаємовідносин зі споживачами. Таким чином, соціальна відповідальність повинна бути частиною бізнес-стратегії компаній, що надають фінансові послуги.

\section{Список використаних джерел}

1. Іваннікова М. М. Маркетингове управління лояльністю споживачів / М. М. Іваннікова // Маркетинг і менеджмент інновацій. 2014. - № 3. - С. 62-72. 
2. Accenture Global Financial Services Consumer Study 2019: Discover the patterns in personality. - [Electronic resource]. - Access mode: https://www.accenture.com

3. Khovrak I. Odpowiedzialność społeczna jako strategia przywództwa przedsiębiorstwa na rynku / I. Khovrak // Zeszyty Instytutu Spraw Publicznych UJ Zarządzanie Publiczne. - 2017. - Numer 3 (39). - S. 391-401.

Шаповал Ю. І.

м.н.с. відділу грошово-кредитних відносин, ДУ «Інститут економіки та прогнозування НАН України», м. Київ, Україна

ORCID ID: https://orcid.org/0000-0001-9965-5522

\section{ФІНТЕХ ЯК ІНСТРУМЕНТ ПІДВИЩЕННЯ ФІНАНСОВОЇ ІНКЛЮЗІЇ БІЗНЕСУ}

Фінансова інклюзія $є$ важливим елементом економічного розвитку, оскільки сприяє взаємодії учасників фінансового ринку та, зокрема, поліпшенню підприємницької ділової активності. Недостатній рівень фінансової інклюзії бізнесу в Україні перешкоджає інвестуванню малих та середніх підприємств (МСП). В той же час, зростають ризики фінансової нестабільності в разі розширення доступу до банківських кредитів без належного контролю.

Розвиток Фінтеху сприяє фінансовій інклюзії за рахунок зниження витрат і розширення спектру послуг. Нові технології, такі як Big Data та хмарні обчислення, полегшують збір та обробку великих обсягів інформації. Для бізнесу кредитний аналіз може спиратися на штучний інтелект і машинне навчання, які поєднують дані реєстрації та обліку МСП з географічною та соціально-економічною інформацією. До того ж технологія блокчейн може покращити процес управління інформацією реєстрів застав і прав власності, та забезпечити безпеку, 
конфіденційність та прозорість децентралізованих платформ. Фінтех, «вбудовуючи» нормативні вимоги в ІТ-протоколи, дозволяє проводити моніторинг в реальному часі, що в свою чергу зменшує витрати на нормативне забезпечення при фінансуванні МСП. Крім того, Фінтех може відігравати важливу роль у посиленні конкуренції між постачальниками фінансових послуг, бо дозволяє розвивати альтернативні способи фінансування бізнесу на додаток до традиційного - банківського кредитування МСП. Так, з'явилися нові електронні платформи, які призвели до розширення краудфандингу (на основі акцій; в обмін на негрошові винагороди із філантропічних мотивів), розвитку кредитування Р2Р (позики без застави від приватних інвесторів), фінансування торгівлі та електронної комерції (у розпорядженні яких великі обсяги інформації про клієнтську базу) [1].

В той же час, Фінтех, збираючи велику кількість даних, створює ризики конфіденційності даних. Разом з тим, багато фінтех-платформ для кредитування спираються на короткострокове фінансування, що може посилити проциклічність кредитних установ при проблемі нестачі ліквідності. Для побудови фінтех-екосистем потрібні низка політичних та інституційних умов, включаючи інфраструктуру та регуляторно-правове середовище. Так, Сінгапур, ОАЕ, Велика Британія вже заснували центри інновацій, де фінтех-компанії можуть перевірити технології фінансування МСП в невеликих масштабах [1].

Таким чином, більш розвинутий і краще регламентований Фінтех може підвищити фінансову інклюзію бізнесу через зміну традиційних способів фінансування МСП. Однак Фінтех асоціюється із ризиками кібербезпеки i, відповідно, необхідністю впровадження належного регулювання, а саме: потрібні розвинені платіжна система й 
інфраструктура, гарантії захисту прав споживачів. Отже, Фінтех може стати важливим каналом фінансових послуг для МСП в економіці України. Водночас, фінансова інклюзія не є еквівалентом фінансового розвитку, оскільки розширення доступу до фінансових послуг не обов'язково призводить до активізації фінансової діяльності.

\section{Список використаних джерел}

1. Blancher N. et. al. Financial Inclusion of Small and Medium-Sized Enterprises in the Middle East and Central Asia. IMF Departmental Paper. 2019. February. № 19/02.

\section{СЕКЦІЯ 5}

\section{ХАЙП-ЦИКЛ РОЗВИТКУ ФІНАНСОВИХ ТЕХНОЛОГІЙ}

Волосович С. В. Київський національний торговельно-економічний університет,

д. е. н., професор

м. Київ, Україна ORCID ID: https://orcid.org/0000-0003-3143-7582

\section{ДОМІНАНТИ РОЗВИТКУ ЦИФРОВОГО БАНКІНГУ}

Підгрунтям розвитку цифрового банкінгу є фінансові технології. FinTech - це інноваційні технології, які використовуються фінансовими інститутами, органами державного управління, торговельними організаціями для задоволення потреб споживачів фінансових, адміністративних послуг та товарів в умовах розвитку економіки споживання $[1$, с. 8$]$.

Банки використовують такі інструменти фінансових технологій як великі дані, штучний інтелект, біометрія, блокчейн, хмарні технології, інтернет, мобільний доступ. Починаючи з 2015 року активізувався розвиток RegTech. Згідно із даними міжнародної 
Асоціації дипломованих сертифікованих бухгалтерів (АССА), кількість змін у нормативно-правовому регулюванні після 2008-2009 років зросла у п'ять разів, внаслідок чого на дотримання всіх вимог співробітники витрачають 10-15\% свого робочого часу [2]. Зрозуміло, що при цьому збільшуються й витрати. Як свідчать дослідження Boston Consulting Group, з 2008 року світові банки сплатили штрафи розміром понад 321 млрд дол. США [3].

Основними моделям взаємодії банків та FinTech-компаній є:

I. Безоплатне копіювання рішень FinTech-компанії на майданчику банку.

II. Придбання ліцензованого рішення у FinTech-компанії.

III. Розподіл доходів від залучення кожного клієнта завдяки рішенню FinTech-компанії.

IV. Створення рішень спільно із FinTech-компанії у межах інкубатора банку, що вимагає додаткового юридичного захисту прав обидвох сторін на створені продукти.

V. Придбання FinTech-компанії із загрозою зниження мотивації у iï працівників у майбутньому.

VI. Модель відкритих інновацій, що передбачає вирішення FinTech-компанією анонсованих банком проблем.

Перспективи розвитку фінансових технологій у банківському секторі:

1. Подальший розвиток необанків, що $\epsilon$ банками, які обслуговують споживачів 3 використанням сайтів та мобільних додатків без наявності у них фізичних відділень. Нині вони є особливо популярними у США та Великобританії.

2. Подальше скорочення робочих місць у банківському секторі. В інтерв'ю телебаченню Bloomberg у 2017 році Вікрам Пандіт, керуючий 
Citigroup Inc. під час фінансової кризи, заявив, що 30\% банківських робочих місць можуть зникнути протягом наступних п'яти років через розвиток технологій [4].

3. Спостерігатиметься активізація розвитку в сфері Open Banking завдяки Директиві PSD2, яка мала відкрити доступ до даних понад 5 тис. європейських банків [5]. За деякими даними цей процес дещо сповільнюється внаслідок неготовності інфраструктури банків до відкриття AРІ та відсутності достатньої мотивації в банків, у результаті чого такі великі банки як Barclays, HSBC, Santander не встигли це зробити до 13.01.2018 [5]. Відкриті банківські АРI дають можливість третім особам користуватися інформацією банку та аналізувати іiі.

4. Використання банкоматів на основі безконтактного обслуговування із застосуванням смартфона та біометрії, що $\epsilon$ наступною модернізацією після введення їх у дію в 1967 році.

5. Поглиблення взаємодії регуляторів та продавців фінтех фінансових послуг.

Отже, у подальшому спостерігатиметься активізація застосування фінансових технологій у банківському секторі.

\section{Список використаних джерел}

1. Мазаракі А., Волосович C. FinTech у системі суспільних трансформацій//Вісник Київського національного торговельноекономічного університету. 2018. №2. С. 5-18.

2. Равнушкин О., Север Я., Куликов Н. Большие надежды банков, или что такое RegTech. URL: https://bloomchain.ru/fintech/bolshie-nadezhdy-bankov-ili-chto-takoeregtech/

3. Finch G. World's Biggest Banks Fined \$321 Billion Since Financial Crisis. URL: https://www.bloomberg.com/news/articles/2017-0302/world-s-biggest-banks-fined-321-billion-since-financial-crisis

4. Csiszar J. 8 New Banking Technologies You'll See in the Next 5 Years. URL: https://www.gobankingrates.com/banking/technology/newbanking-technology/ 
5. Шевченко A. Банки VS стартапы: от наблюдателей до активных партнеров. URL: https://psm7.com/fintech/banki-vs-startapy-otnablyudatelej-do-aktivnyx-partnerov.html

Gordiienko T. M.

PhD (Economics), Associate professor Kyiv National University of Trade and Economics,

Kyiv, Ukraine

ORCID ID: http://orcid.org/0000-0001-7812-3877

\section{LEGISLATIVE INITIATIVES FOR THE DIGITAL TRANSFORMATION OF BANKING BUSINESS}

The level of development of legislation regulating the activities of digital banks and digital services of traditional banks in different countries is significantly different. Significant activation of legislative initiatives in the field of digitalization of the banking sector has been observed during 2016- 2018.

The key aspects that require special attention during the digitalization of banking business are: licensing of digital banks, identification of clients and providing data protection.

One of the first legislative acts to significantly simplify the provision of digital services is the EU Payment Services Directive (PSD2) 2015/2366 [1], which came into force in January 2016. By January 2018, all European countries had to implement its provisions in national law. U.S. Banks and third-party providers (TPP) have to comply with the Payment Services Directive 2 (PSD2) requirements on strong customer authentication by September 14, 2019. Following publication of the final PSD2 Regulatory Technical Standards (RTS), financial institutions are actively preparing and implementing their PSD2 compliance strategy. 
On May 25, 2018, the GDPR: General Data Protection Regulation became the main legal framework for data protection in the EU. The objective of the GDPR is to give control over personal data to EU citizens and residents. No matter where they are based, companies that handle data belonging to EU citizens must comply with the GDPR or face severe financial penalties [2].

Meanwhile, in the U.S., Economic Growth, Regulatory Relief and Consumer Protection Act, commonly known as the Dodd-Frank repeal, signed in May 2018, not only removes many of the regulations imposed on banks in the wake of the Great Recession, but it also bears particular relevance to mobile banking and e-signatures. The new law includes a provision called the MOBILE Act (Making Online Banking Initiation Legal and Easy). This provision makes it easier for banks to onboard new customers remotely without the need for the customer to travel to a branch to complete the process [3].

Mentioned regulatory initiatives, whether heading toward greater restrictions or deregulation, aim to create a digital banking environment that enables innovation and ongoing digitalization, as well as protecting consumers of digital services.

\section{References}

1. Directive (EU) 2015/2366 of the European Parliament and of the Council on payment services in the internal market. - Access mode: https://eurlex.europa.eu/legal-content/ENTXT/PDF/?uri=CELEX:32015L2366\&from=FR

2. The EU General Data Protection Regulation (GDPR) is the most important change in data privacy regulation in 20. - Access mode: https://eugdpr.org.

3. Top Banking Regulations \& Security Compliance Requirements For 2018. Posted on August 28, 2018 by Michael Magrath.- Access mode: https://www.corporatecomplianceinsights.com/top-banking-regulations-securitycompliance-requirements-for-2018. 
Городянська Л. В.

к. е. н., доцент

Військовий інститут Київського національного університету імені Тараса Шевченка, м. Київ, Україна ORCID ID: http://orcid.org/0000-0002-4482-1690

\section{ОСОБЛИВОСТІ ФУНКЦІОНУВАННЯ НЕОБАНКІВ}

Світові інноваційні процеси, удосконалення форм комунікації і передачі даних призвели до загострення конкуренції у банківській сфері й поступової зміни уподобань і вимог населення до видів банківських послуг. Розвиток цифрових і сучасних інформаційних технологій, доступність мережі Internet і мобільного зв'язку на основі нового покоління смартфонів та планшетів сприяло появі нової форми банку - інтернет-банку, який зазвичай працює без офісів. Так, перший інтернет-банк з'явився у Великій Британії ще у 1998 році та став прототипом банку-челенджера (Challenger Bank). Це концептуально інноваційна форма банку, яку на практиці ще називають необанк.

Поява необанку сприяла розширенню сфери банківських послуг, проведенню операцій у віртуальній цифровій формі й успішній оптимізації власних витрат. Необанки мають сучасний функціонал, а для надання банківських послуг використовують мережу Internet (сайти, кабінети) й мобільні додатки. Нещодавно з'явившись закордоном, необанк, як нова форма фінансово-кредитної установи, успішно адаптується на ринку банківських послуг України. В контексті цього виникає потреба у дослідженні економічних переваг і недоліків функціонування необанку.

Метою дослідження $є$ аналіз основних переваг та недоліків системи функціонування необанків. 
Законодавчо-правовою основою створення необанку є банківська ліцензія. Також необанк може функціонувати на основі вже існуючого банку завдяки оптовій купівлі послуг у фінансової організації, яка має ліцензію, і продаючи їх у роздріб кінцевим споживачам (клієнтам банку). Перевагами необанків є:

- оптимальна система, що дозволяє спростити процедуру реалізації фінансових послуг і залучити нові інструменти, наприклад, такі як: Р2Р-кредитування, краудфандінгові платформи, фінансові роботиконсультанти, криптовалюта;

- низькі відсоткові ставки; нижчий рівень комісії порівняно 3 традиційними банками або його відсутність;

- сучасний інтерфейс для клієнтів, зручний та зрозумілий формат інтернет-банкінгу; високий рівень обслуговування та підтримки користувачів банківських послуг;

- можливість швидкої оплати рахунків і встановлення, за бажанням клієнта, тижневих лімітів витрат за картками тощо.

Стрімкий ріст необанків за останні декілька років відбувається шляхом проведення банківських операцій у віртуальній цифровій формі. Це виявило низку проблем та недоліків, пов'язаних з:

- високим рівнем конкуренції та витрат у короткостроковій перспективі на залучення нових клієнтів;

- вартістю володіння контентом, умовами дотримання фінансової безпеки та недоторканості персональних даних клієнтів;

- недовірою до конвертації окремих платіжних засобів;

- необхідністю конкурувати не лише з традиційними банками, а й протистояти таким брендовим компаніям, як Google, Apple, WeChat та 
Uber, які мають доступ до даних значної бази клієнтів та пропонують ним асортимент фінансових інструментів.

Світові економічні та політичні зміни також значною мірою впливають на даний сегмент ринку банківських послуг.

Висновки: отже, відмова від застарілої ІТ-інфраструктури, застосування сучасних девайсів та оптимальної системи безпеки надає необанкам конкурентні переваги порівняно 3 традиційними банками завдяки зниженню рівня їх операційних витрат та розширенню можливостей сучасних банківських послуг. Залучення нових клієнтів потребує забезпечення надійного захисту персональних даних з метою зростання довіри до необанків та удосконалення інтернет-банкінгу.

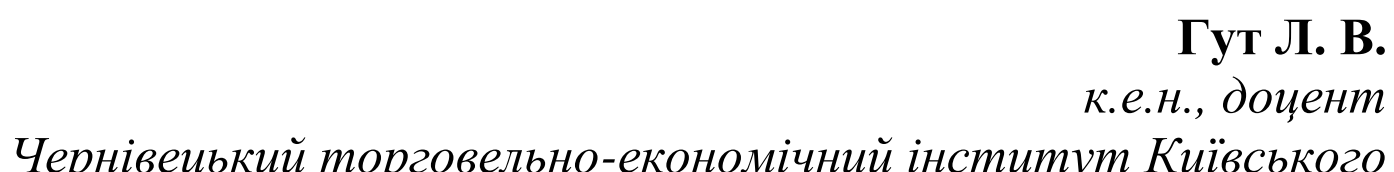
національного торговельно-економічного університету, м. Чернівиі, Україна

\section{НЕОБАНКИ: ЗАРУБІЖНИЙ ТА ВІТЧИЗНЯТИЙ ДОСВІД ФУНКЦІОНУВАННЯ}

Активне впровадження інформаційних технологій характерне i для фінансових послуг,, які через мережу Інтернет забезпечують доступність банківських продуктів та послуг для клієнтів, усунувши географічні та часові бар'єри для їх надання. Наявність смартфонів та мобільних додатків сприяла появі необанків. Їх називають по-різному: «необанк», «мобільний банк», «віртуальний банк», «інтернет-банк», «цифровий банк», за кордоном - «банк-челенджер»(Challenger Bank). Таке визначення застосовується до всіх банків, що виходять за рамки класичного обслуговування [1]. 
Більшість науковців схиляються до того, що необанк - це фінансово-кредитна установа, яка здійснює банківські операції виключно через мережу Інтернет та сучасні технологічні платформи.

Особливістю необанків є те, що окрім традиційних банківських послуг (рахунки і операції за ними, кредити, управління капіталом, інвестиції, депозити тощо) вони прагнуть використовувати й новітні інструменти: Р2Р-кредитування, краудфандінгові платформи, фінансових роботів-консультантів та криптовалюту; пропонують вищі процентні ставки, більш низький рівень комісій (або взагалі їх відсутність) і вищий рівень обслуговування та підтримки клієнтів.

Вивчення закордонного досвіду свідчить про те, що станом на 01.01.2017 р. 70 компаній зі сфери необанкінгу знаходяться у Великобританії, Китаї, Індії, США, Франції, Німеччині, Іспанії, Бразилії, Італії, Канаді та в Південній Кореї; вони мають можливість отримувати банківську ліцензію, або оперувати на базі одного 3 існуючих банків (купуючи оптом послуги у фінансової організації, яка надає ліцензію, і продаючи їх в роздріб своїм клієнтам); дистанційно відкривати депозити і оформляти кредити або ж отримати іпотеку; надавати весь сервіс через мобільний додаток, ввійти в який можна за допомогою функції розпізнавання обличчя та голосу.

У СС згідно Директиви про надання платіжних послуг (PSD2) всі фінансові установи 32018 р. надають, враховуючи вимоги до необанкінгу [1].

Нами проведено дослідження з метою порівняння надання послуг трьома банками м.Чернівці станом на 1.01.2019 p.: Monobank, AT «ПриватБанк» та АТ «Альфа-банк». Monobank - це перший мобільний банк, клієнтами якого можуть стати лише користувачі смартфонів. Monobank - це Інтернет-банк, який на відміну від АТ«ПриватБанк» та 
АТ«Альфа банк» більш лояльніший до клієнтів: в нього збільшений пільговий період на 7 днів (з 55 днів до 62 днів); відсоткова ставка вигідніша (на 0,4\% вища ніж у АТ«ПриватБанк» та 0,1\% ніж 3 АТ«АльфаБанк»); для клієнтів відсутня комісія при оплаті комунальних послуг та при поповнення мобільного телефону і т.д. (від 2 грн. АТ«ПриватБанк» до 5 грн. АТ «АльфаБанк» за рахунок власних коштів, за рахунок кредитних коштів у АТ«Приват Банк» комісія складає 1\%+1-5 грн., а у АТ«Альфа банк» - відповідно 4\%+2 грн); при знятті готівки Monobank використовує комісію у розмірі 0,5\% за рахунок власних коштів, відповідно АТ«ПриватБанк» - 1\%, АТ «АльфаБанк» - 4\%; наявність для клієнтів кешбекку - це повернення частини грошей за покупки, здійснені за допомогою картки Monobank (до 20\%), у АТ«Приватбанк» він взагалі відсутній, а в АТ «Альфа Банк» складає лише до 5\%.

Отже, застосування необанкінгу сприяє економії операційних витрат на утримання персоналу та приміщень банку, а для клієнтів, які користуються мобільними додатками інтернет-банків, дозволяє зручно, швидко і вигідно на більш лояльних умовах (поза банківською установою) отримувати банківські послуги. [2]

\section{Список використаних джерел}

1. Необанки: майбутнє або тупикова гілка розвитку банківської системи [Електронний ресурс] / Режим доступу : https://news.finance.ua/ua/news/-/403187/neobanky-majbutnye-abotupykova-gilka-rozvytku-bankivskoyi-systemy

2. Необанки: закордонна історія та українська перспектива [Електронний gazeta.com/publications/

practice/ ресурс]/Режим доступу:http://yurperspektiva.html

inshe/neobanki-zakordonna-istoriya-ta-ukrayinska- 
Калита О. В.

к.е.н., асистент

Київський національний торговельно-економічний університет, м. Київ, Україна ORCID ID: http://orcid.org/0000-0003-2020-5751

\section{ВІРТУАЛЬНІ БАНКИ : ПЕРСПЕКТИВИ РОЗВИТКУ}

Розвиток інформаційних технологій в другій половині XX початок XXI століття призвело до створення інформаційної економіки, що базується на застосування сучасних досягнення науки і техніки. 3 появою глобальної мережі Інтернет забезпечило формування нових форм корпорацій. Вперше визначення «віртуальна корпорація» була опублікована в монографії у 1992 році [1]. Успішний розвиток віртуального підприємства сприяло розвитку аналогічної форми в фінансовій сфері - віртуальних банків. Передумовою створення першого віртуального банка було впровадження системи дистанційного обслуговування клієнта. Зокрема, інтернет-банкінг (Online banking, e-banking,Internet banking) - надання банківських послуг через електроні канали передачі інформації.

В таких умовах виникає ідея створення віртуального банка - без відділень i офісів. Сайт такого банка $\epsilon$ основним i єдиним «відділенням», де можна отримати всю необхідну інформацію, обрати продукт банка, контролювати рахунки, а також отримувати підтримку спеціаліста в онлайн-режимі.

В світі сьогодні нараховують, за різними оцінками експертів, від декількох сотень до одної тисячі вітуальних банків, особливо значний розвиток відбувається в США. Одним з перших віртуальний банк, що 3’явився в Америці - Security First Network Bank (1995 рік). У Свропі подібна фінустанова з'явилася через рік у Німеччині під назвою 
Advance Bank [2]. В Україні така форма надання банківських послуг, не отримало широкого поширення. У 2017 році був запущений Monobank [3]. Проте, сам по собі він не є віртуальним банком в класичній формі. Фактично, Monobank - це просто онлайн-платформа, що прив'язана до Universal банку. Monobank пропонує кешбек. Залежно від виду товарів і послуг, за які клієнт Monobank буде платити карткою, йому повернеться на рахунок від 2 до 20\% від вартості товару чи послуги [3]. Наявність подібної послуги на ринку має простимулювати розвиток конкуренції на ринку банківських послуг в сфері обслуговування громадян.

Monobank може стати першим кроком до створення віртуальних банків в України. Наявність таких банків буде сприяти збільшенню обсягів безготівкових розрахунків.

\section{Список використаних джерел}

1. Davidow W., Malone M. The Virtual Corporation: Structuring and Revitalizing the Corporation for the 21st Century. New York : Harper Collins. - $1992-186$ p.

2. Що таке Monobank, кому він належить і що пропонує сьогодні. [Електронний режим]. - Режим доступу: https://section.in.ua/brands/monobank/

3. Офіційний сайт Monobank [Електронний режим]. - Режим доступу: https://www.monobank.ua/?lang=ru/

Озерчук О. В. к.е.н., старший викладач Київський національний торговельно-економічний університет м. Київ, Україна ORCID ID: http://orcid.org/0000-0003-3827-080X

\section{ON-LINE БАНКИ: ЗАРУБІЖНИЙ ДОСВІД}

Банківська сфера XXI сторіччя ознаменувалася появою нових інформаційних технологій ведення банківського бізнесу та надання 
банківських послуг нового покоління. Зокрема, мова йде про створення оnline банків, які не мають фізичних відділень для обслуговування клієнтів. Піонером у цій сфері був банк N26, який стартував як фінансовотехнологічний стартап у Німеччині у 2013 році. Спочатку N26 працював за підтримки та з гарантіями німецького банку Wirecard Bank, а восени 2016 року він отримав банківську ліцензію від німецького регулятора BaFin та погодження від Європейського Центрального Банку. Це означає, що рахунки відкриті в N26 підкріплені Гарантійним фондом з покриттям до 100000 євро.

Нині послуги N26 доступні у 24 європейських країнах для 2,3 млн клієнтів, включаючи Великобританію. У 2018 році банк збільшив кількість клієнтів у тричі та планує вийти на ринок США у 2019 році. N26 заробляє на комісіях за перекази по картам, преміям- екаунтах, а також на фінансових продуктах: овердрафтах, споживчих кредитах та інших. N26 оцінюють у 2,7 млрд дол. США та у компанії працює більше 800 співробітників у Берліні, Барселоні та Нью-Йорку. Основними конкурентами N 26 є фінансові стартапи - Revolut, Monzo, Starling i Atom [1].

N26 є прямим банком, що спеціалізується на управлінні рахунками через смартфон. Його основною ідеєю $є$ те, що кращий банківський офіс - це мобільний телефон, а у центрі всього повинен стояти клієнт [2].

Серед переваг N26: (1) реєстрація за 8 хвилин; (2) миттєві грошові перекази; (3) перегляд інформації по своїх рахункам i транзакціям с мобільного телефону в режимі реального часу , а також блокування своєї карти в один клік через додаток, який доступний безкоштовно для Android та iOS; (4) відсутність паперового документообміну; (5) верифікація документів в он-лайн режимі; (6) 
відсутність комісій по операціям с картами банку, у тому числі і за кордоном; (7) можливість вносити і знімати готівку в будь-якому банкоматі, який приймає MasterCard по всьому світу без комісій; (8) можливість зняття готівки з рахунку банку у звичайних магазинах $\mathrm{i}$ аптеках; (9) можливість інвестувати кошти зі свого рахунку тощо.

У майбутньому N26 планує розробити для своїх клієнтів платформу, на якій вони могли б здійснювати практично будь-які маніпуляції зі своїм рахунком в одному додатку на смартфоні.

В Україні також функціонує банк без відділень - Монобанк. Проте, по факту - це роздрібний продукт АТ «Універсал Банк», який виник в рамках співробітництва 3 командою Fintech Band. В рамках monobank $є$ можливість розміщення депозитів і отримання інших послуг. Монобанк працює тільки на мобільних пристроях [3].

На думку інвестиційних експертів, фінансово-технологічні стартапи є одним з найперспективніших напрямів для інвестування [4].

\section{Список використаних джерел}

1. Banking startup $\mathrm{N} 26$ raises $\$ 300$ million at $\$ 2.7$ billion valuation [Електронний ресурс]. - Режим доступу: https://techcrunch.com/2019/01/09/n26-raises-300-million-at-2-7-billionvaluation/?guccounter $=1$

2. N26 GmbH [Електронний ресурс]. - Режим доступу: https://n26.com/en-de/about-n26

3. Монобанк. Про банк. [Електронний ресурс]. - Режим доступу: https://www.monobank.ua/about?lang=uk

4. Сергій Кравець. Майбутнє fintech. Компанії, які змінюють світ грошей вже сьогодні [Електронний ресурс]. - Режим доступу: https://news.finance.ua/ua/news/-/444441/sergij-kravets-majbutnyefintech-kompaniyi-yaki-zminyuyut-svit-groshej-vzhe-sogodni 
Serazhym Y. V.

PhD (Economics), Associate professor Kyiv National University of Trade and Economics Kyiv, Ukraine ORCID ID: http://orcid.org/0000-0002-2295-7095

\section{THE HYPE CYCLE FOR EMERGING TECHNOLOGIES ON THE BOUNDARY BETWEEN MAN AND MACHINE}

The Hype Cycle for Emerging Technologies is unique among most Hype Cycles because it garners insights from more than 2,000 technologies into a succinct set of 35 emerging technologies and trends. This Hype Cycle specifically focuses on the set of technologies that is showing promise in delivering a high degree of competitive advantage over the next five to 10 years (see Figure 1).

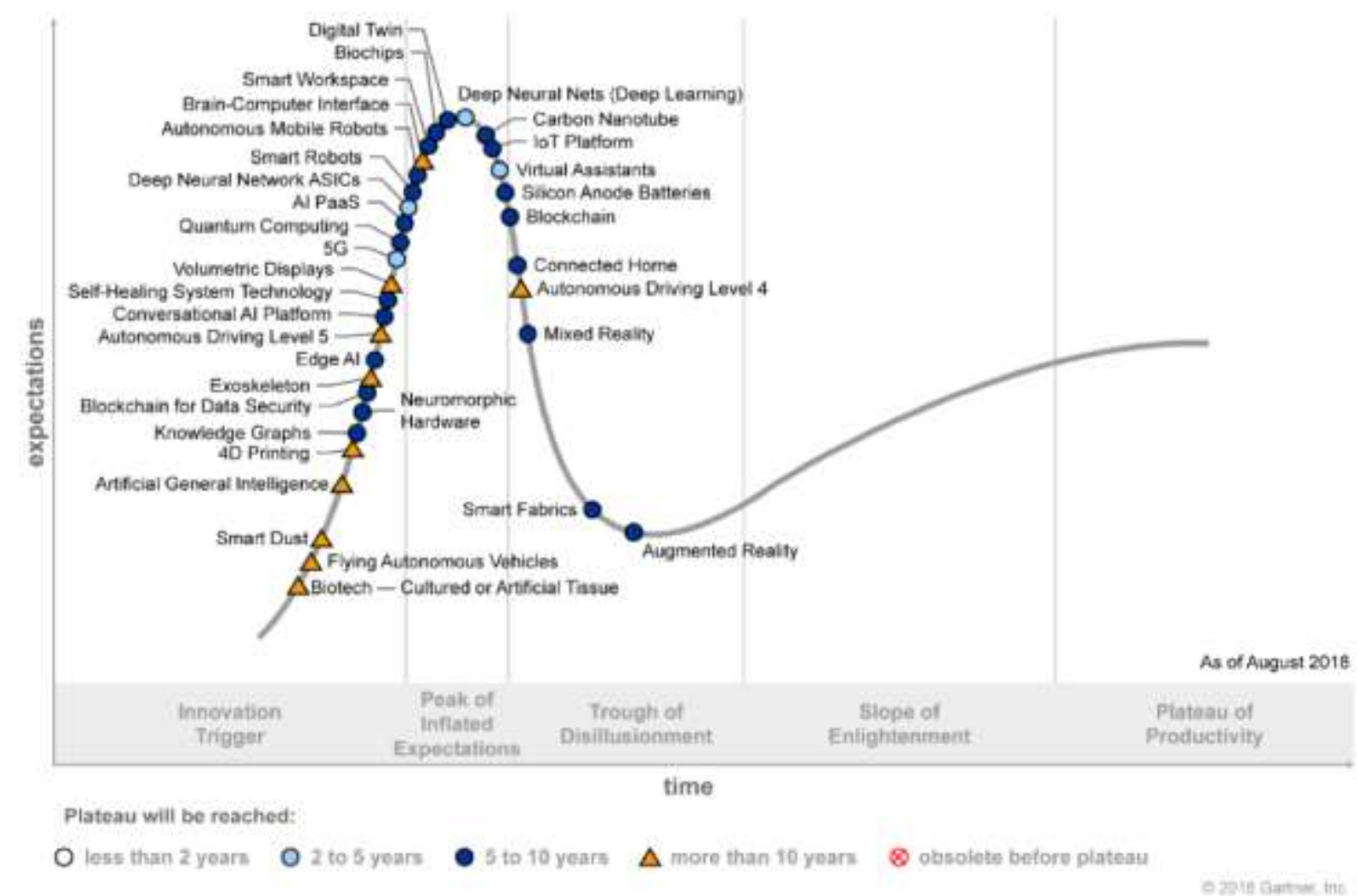

Figure 1. Hype Cycle for Emerging Technologies [1] 
Five Emerging Technology Trends

- Democratized AI. AI technologies will be virtually everywhere over the next 10 years. While these technologies enable early adopters to adapt to new situations and solve problems that have not been encountered previously, these technologies will become available to the masses democratized. Movements and trends like cloud computing, the "maker" community and open source will eventually propel AI into everyone's hands.

This trend is enabled by the following technologies: AI Platform as a Service (PaaS), Artificial General Intelligence, Autonomous Driving (Levels 4 and 5), Autonomous Mobile Robots, Conversational AI Platform, Deep Neural Nets, Flying Autonomous Vehicles, Smart Robots, and Virtual Assistants.

-Digitalized Ecosystems. Emerging technologies require revolutionizing the enabling foundations that provide the volume of data needed, advanced compute power and ubiquity-enabling ecosystems. The shift from compartmentalized technical infrastructure to ecosystem-enabling platforms is laying the foundations for entirely new business models that are forming the bridge between humans and technology. This trend is enabled by the following technologies: Blockchain, Blockchain for Data Security, Digital Twin, IoT Platform and Knowledge Graphs.

- Do-It-Yourself Biohacking. Over the next decade, humanity will begin its "transhuman" era: Biology can then be hacked, depending on lifestyle, interests and health needs. Biohacking falls into four categories: technology augmentation, nutrigenomics, experimental biology and grinder biohacking. However, questions remain about how far society is prepared to accept these kinds of applications and what ethical issues they create. This trend is enabled by the following technologies: Biochips, Biotech - Cultured 
or Artificial Tissue, Brain-Computer Interface, Augmented Reality, Mixed Reality and Smart Fabrics.

- Transparently Immersive Experiences. Technology will continue to become more human-centric to the point where it will introduce transparency between people, businesses and things. These technologies extend and enable smarter living, work, and other spaces we encounter. This trend is enabled by the following technologies: 4D Printing, Connected Home, Edge AI, Self-Healing System Technology, Silicon Anode Batteries, Smart Dust, Smart Workspace and Volumetric Displays.

- Ubiquitous Infrastructure. Infrastructure is no longer in the way of obtaining an organization's goals. The advent and mass popularity of cloud computing and its many variations have enabled an always-on, available and limitless infrastructure compute environment.

This trend is enabled by the following technologies: $5 \mathrm{G}$, Carbon Nanotube, Deep Neural Network ASICs, Neuromorphic Hardware and Quantum Computing.

Technologies supporting ubiquitous infrastructure are on track to reach the peak and move fast along the Hype Cycle. 5G and deep neural network ASICs, in particular, are expected to reach the plateau in the next two to five years.

\section{References}

1. Gartner. Official website: [Electronic resource]. - Access mode: https://www.gartner.com/ 
Підвисоцький Я. В.

к.е.н., асистент

Інститут міжнародних відносин Київського національного університету імені Тараса Шевченка

м. Київ, Україна

\section{БІО-ЦИКЛ ТА ХАЙП-ЦИКЛ ЗАРОДЖЕННЯ І РОЗВИТКУ ІННОВАЦІЙНИХ ФІНАНСОВИХ ІНСТРУМЕНТІВ}

У сучасних умовах світової економіки фінансові інновації стали вирішальним елементом системи міжнародних фінансів, покликаним вирішувати важливі практичні задачі оптимізації розподілу капіталу. Оптимізація може бути досягнута шляхом конструювання нової, відмінної від традиційної системи прав та зобов'язань за міжнародними контрактами, а тому, подібно біологічному організму, має проходити у процесі зародження та розвитку декілька послідовних етапів.

За визначенням родоначальника інноваційних процесів у теорії та практиці фінансів, автора поняття «фінансовий інжиніринг» Дж. Фіннерті, фінансова інженерія означає «проектування, розробку i реалізацію інноваційних фінансових інструментів та процесів, а також творчий пошук нових підходів до вирішення проблем у сфері фінансів». [1, с. 20-23].

Отже, у відповідності до визначення, проектування і розробка $є$ тривалим процесом, який можна розділити на декілька етапів. Ці етапи за методом аналогій дуже тісно пов'язані із біологічним процесом поділу хромосом, а тому ми назвемо його біо-циклом зародження інноваційного фінансового інструменту.

Таким чином, виділимо та проаналізуємо наступні етапи (фази) утворення нового фінансового інструменту. 
Профаза (підготовка компонентів прав і зобов'язань елементарних інструментів, укомплектування прав та зобов'язань контрагентів за різними інструментами, обмін частинами фінансових інструментів, об'єднання різнорідних властивостей елементарних інструментів, конкретизація прав i зобов'язань за кожним новоутвореним інструментом).

Метафаза (структуризація прав та зобов'язань відносно певного параметру чи системи параметрів).

Анафаза (утворення двох полярно різних структур з наборів властивостей прав і зобов'язань).

Телофаза (новоутворені структури отримують юридичні назви і законодавчо закріплюються у вигляді норм приватного, а згодом i публічного права) [2, с. 424-428].

Фази є послідовними, взаємозалежними і такими, що не можуть існувати одна без одної, в іншому випадку система буде порушеною, а інструмент не придатний до використання.

Коли інноваційний фінансовий інструмент досягає зрілості шляхом проходження процедури «скринінгу», він проходить п’ять послідовних економічних циклів, що у науковій термінології називаються циклами хайпа або хайп-циклами (англ. - Hype cycle). Сутність циклів полягає у різному характері економічних очікувань від застосування новоутвореного інструменту у практичній діяльності, тобто на ринку. В залежності від мети використання - управління ризиками, фандрайзингу, позиціонування чи спекулятивних операцій очікування набувають багатогранних рис, синтез яких може проявлятися у таких видах хайп-циклів:

1. Технологічна поява (тригер). На цьому етапі споживачі освоюють новостворений фінансовий продукт; обережно починають 
тестувати та імплементувати його до сфери використання; оцінюють переваги та недоліки; аналізують наслідки і механізми дій та поведінки.

2. Пік надмірних очікувань. Цей етап характеризується, поперше, успішними результатами попереднього, по-друге, пошуком розширення сфер застосування, широким обговоренням у наукових i практичних колах, а по-третє, і найголовніше, очікуваннями від інструменту того, що він здатний радикально вирішити нерозв'язані до цього моменту задачі оптимізації капіталу.

3. Позбавлення від ілюзій. Коли інновація з часом починає все гірше справлятися із поставленими завданнями, тим самим не виправдовуючи покладених на неї очікувань, на фінансовому ринку відбувається поступова відмова від використання такої інновації. Причинами можуть бути і ускладнення типів завдань, і обмеженістю умов, за яких функціонує інструмент, і нові фактори, що ускладнюють процес оптимізації тощо.

4. Подолання недоліків. Будучи навченими результатами недосконалості дії інструменту, фінансові інженери намагаються виправити помилки шляхом видалення із моделі зайвих прав i зобов'язань за контрактами та імплементації необхідних нових пунктів контракту, здатних посилити ефективність дії у розв'язанні поставлених завдань.

5. Плато продуктивності. Удосконалений інструмент набуває нових рис і форм разом зі старими, утворюючи усталену архітектуру правових механізмів. У споживачів продукту вже сформовані позитивні та негативні стереотипи, визначене усталене критичне сприйняття переваг і недоліків, які можна з часом трансформувати. [3, c. 36-39] 
Серед новітніх фінансових інструментів, які подолали етапи біоциклів та хайп-циклів, особливу увагу слід звернути на кредитний дефолтний своп (англ. - CDS).

Перший інструмент був створений у 1994 році Б. Мастерс 3 метою уникнення дорогого інструменту страхування кредитних ризиків. У основу створення було закладено новітній інструмент дезагрегації пулу ризиків та передачі їх страхувальникам-емітентам на умовах випадкових подій. Цікавою особливістю цього фінансового інструменту стало те, що він швидко досяг порогу зрілості, а також спричинив непоправні наслідки останньої світової фінансової кризи на другому хайп-етапі своєї зрілості. Очікування були настільки високими, що позабіржовий обіг цих інструментів майже сягнув подвійного показника ВВП у 2007-му році - більш як 107 трлн. дол. [4] Натомість після етапу розчарування та незавершеного етапу подолання ризиків кредитний дефолтний своп так і не вийшов на той рівень плато продуктивності, який би залишив йому шанс на позитивний стереотип з боку споживачів.

Таким чином, підготовка до створення інноваційних фінансових інструментів потребує ретельного аналізу і прогнозування можливих наслідків, аби, проходячи етапи зрілості, такі нововведення ставали максимально досконалим фінансовим продуктом, здатним ефективно вирішувати поставлені завдання.

\section{Список використаних джерел}

1. Joseph E. Finnerty. How to Manage Corporate Cash Effectively / Joseph E. Finnerty. // Paperback Book, 1991. - 225 p.

2. Ченцов Ю.С. Введение в клеточную біологію. / Ю.С. Ченцов. // 4-е изд. Перераб. и доп. - М.: ИКЦ «Академкнига», 2004 $495 \mathrm{c.}$

3. Fenn, Jackie and Raskino, Mark. Mastering the Hype Cycle. Harvard Business Press, 2008. - 339 c. 
4. ISDA: International Swap \& Derivatives Association // Market survey historical data. [Електронний ресурс]. - Режим доступу:

http://www2.isda.org/functional-areas/research/studies

Шуплат О. М.

к.е.н., доиент

ДВНЗ «Київський національний економічний університет

імені Вадима Гетьмана»

м. Київ, Україна

\section{ХАЙП-ЦИКЛ БЛОКЧЕЙНА ТА КРИПТОВАЛЮТ}

Останнє десятиліття показує, що блокчейн багато в чому повторює історію інших перспективних технологій i, подібно до них, знаходиться на своєму шляху до зрілості і поширенню.

«Цикл хайпа», або «цикл зрілості», для перспективних технологій був вперше опублікований фахівцями дослідницької компанії Gartner в 1995 році і зараз є однією з основних концепцій індустрії високих технологій. Цей цикл описує стандартну модель впровадження і процес, який проходять нові технології на шляху до зрілості. Основними етапи є:

Тригер інновації - потенційний технологічний прорив призводить індустрію та суспільство в рух. На цій стадії, як правило ще не існує застосовних на практиці продуктів, а їх комерційна життєздатність ще не доведена. Для блокчейна як технології тригером інновації став whitepaper (меморандум) біткоіни, опублікований в 2008 р. Сатоши Накамото. У цьому документі, названому «Біткоіни: система цифрової пиринговой готівки», описувалася робота нової цифрової грошової системи, яка для створення і поширення, не потребувала ні банки для виконання транзакцій, ні держави. 
Пік завищених очікувань. Очікування від криптовалюти досягли максимуму після появи Ethereum в 2014 р. проте, по-справжньому неможливого від них почали очікувати в 2017 р., в період кріптоманії та ринкових спекуляцій. Якраз через останні чинників курс біткоіна на піку коштував майже 20 тис. дол. США, продемонструвавши зростання приблизно в 1900\% в порівнянні з поч. 2017 р., а ціна «ефіру», незважаючи на всі невирішені технологічні обмеження, зросла на 13000\%. В цілому, за період з 2014 по 2017 р., очікування досягли безпрецедентних рівнів. Створювалися сотні стартапів і токенів, мільярди доларів вкладалися в не дуже багатообіцяючі проекти. Переважна більшість цих проектів не отримала розвитку, багато $з$ них стали аферами [1].

Прірва розчарування - інтерес до технології спадає в міру того, як експерименти і спроби впровадження не виправдовують очікувань. Цей спад призводить до витіснення багатьох виробників з ринку і до «протверезіння» інших. Інвестування триває, за умов що залишилися на ринку постачальники які в змозі поліпшити свої продукти в достатній мірі для того, щоб задовольнити перших клієнтів. Так, 2018 р. був по-справжньому драматичним періодом. На сьогоднішній день масові настрої схиляються в бік скептицизму й обережності. Ціни на криптовалюту значно знизилися. Наприклад, в 2017 р. ціна на біткоін досягла історичного максимуму 19783 дол. США. Проте, вже на поч. 2019 р. ціна становить 5463 дол. США. [2]. Крім того, проекти провалюються і багато хто не впевнений, що технічні проблеми, пов'язані з масштабуванням i ергономічності можна подолати в принципі.

Підйом освіти - починає з'являтися все більше прикладів того, як нова технологія може бути корисна індустрії, що призводить до більш 
широкого і точного іiі розуміння. Постачальники випускають на ринок продукти другого і третього поколінь. Все більше число підприємств роблять спроби впровадження нової технології; більш консервативні компанії продовжують ставитися до неї 3 обережністю. Так, асоціація швейцарських банкірів випустила керівництво для банків, які бажають вести справи з блокчейн-стартапами, а Грошовокредитне управління Сінгапуру заявило, що бажає надавати підтримку кріптовалютним компаніям в отриманні банківських послуг, допомагаючи банкам і стартапам у встановленні відносин і досягнення взаєморозуміння. Деякі з найбільш великих гравців на Уолл-стріт вже готуються працювати в мережі Bitcoin і з криптовалюта в цілому.

Плато продуктивності - починається масове впровадження. Більш чітко визначаються критерії оцінки життєздатності постачальників. Широкий спектр практичного застосування і актуальність технології стають очевидні.

Отже, на сьогоднішній день за оцінками компанії Gartner, цикл зрілості технологій блокчейн знаходиться на рівні фази позбавлення ілюзій. Середня тривалість стадії розчарування для перспективних технологій становить 2-4 роки. Тому, ніхто точно не знає, коли технологія блокчейн досягне зрілості і масового застосування. Деякі експерти стверджують, що це трапиться в 2020-2021 pр., інші вважають більш реалістичним орієнтиром 2025 р. [3]. Проте вже зараз стає зрозумілим, що ця технологія рано чи пізно виросте в революційну.

\section{Список використаних джерел}

1. Хайп-цикл блокчейна и криптовалют. Часть 1: о текущем положении вещей [Електронний ресурс]. - Режим доступу: https://tgraph.io/Hajp-cikl-blokchejna-i-kriptovalyut-CHast-1-Otekushchem-polozhenii-veshchej-01-14 
2. Міністерство фінансів України. Курс крипто валют до долара. [Електронний ресурс]. - Режим доступу: https://minfin.com.ua/currency/crypto/

3. Хайп-цикл блокчейна и криптовалют. Часть 2: Что нас ждет в будущем [Електронний ресурс]. - Режим доступу: https://ethclassic.ru/2019/01/02/blockchain-and-crypto-hype-cycle-2/ 


\title{
ФІНАНСОВО-КРЕДИТНІ СИСТЕМИ В УМОВАХ ЗМІНИ ДІЛОВИХ ЦИКЛІВ
}

\author{
Тези доповідей \\ Міжнародної науково-практичної \\ Інтернет-конференції \\ (Київ, 15 травня 2019 року)
}

Видавець і виготовлювач

Київський національний торговельно-економічний університет вул. Кіото, 19, м. Київ, Україна, 02156 Свідоцтво суб'єкта видавничої справи серія ДК № 4620 від 03.10.2013 p. 